Supporting Information for

\title{
Cytotoxic Tigliane Diterpenoids from Croton damayeshu
}

Jiao-Jiao Cui, ${ }^{\dagger, \dagger}$ Kai-Long $\mathrm{Ji}^{\dagger}{ }^{\dagger}$ Hong-Chun Liu, ${ }^{\dagger}$ Bin Zhou, ${ }^{\dagger}$ Qun-Fang

Liu, ${ }^{\dagger}$ Cheng-Hui Xu, ${ }^{\dagger}$ Jian Ding, ${ }^{\dagger}$ Jin-Xin Zhao, ${ }^{*}, \dagger$ and Jian-Min Yue ${ }^{* \dagger, \dagger}$

${ }^{\dagger}$ State Key Laboratory of Drug Research, Shanghai Institute of Materia Medica,

Chinese Academy of Sciences, 555 Zuchongzhi Road, Shanghai 201203, People's

Republic of China

${ }^{+}$University of Chinese Academy of Sciences, No. 19A Yuquan Road, Beijing 100049, People's Republic of China

General Experimental Procedures.

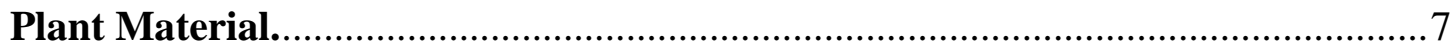

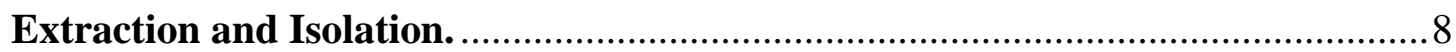

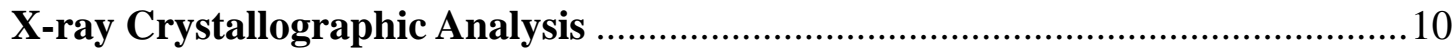

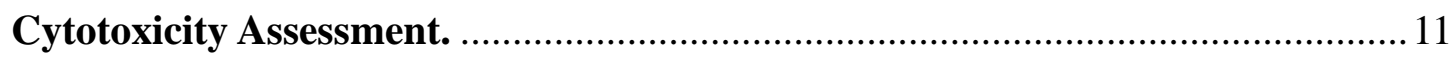

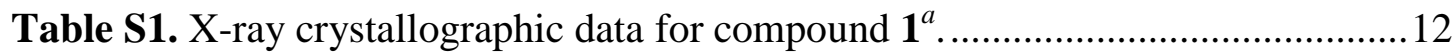

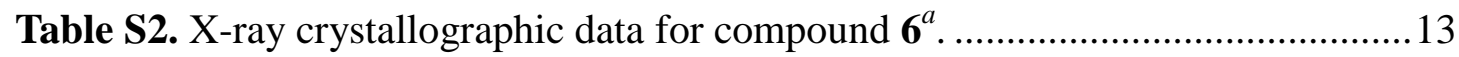

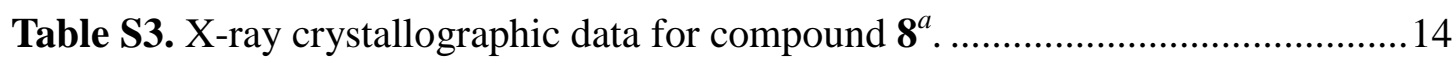

Figure S0. The structure of the tigilanol tiglate and phorbol 12-myristate-13-acetate (PMA)

Figure S1. ${ }^{1} \mathrm{H}-{ }^{1} \mathrm{H} \operatorname{COSY}(\mathbf{A})$, key $\operatorname{HMBC}$ (A) and NOESY (B) correlations of compound 2 15

Figure S2. ${ }^{1} \mathrm{H}-{ }^{1} \mathrm{H} \operatorname{COSY}(\mathbf{A})$, key $\operatorname{HMBC}$ (A) and NOESY (B) correlations of compound 3 . 
Figure S3. ${ }^{1} \mathrm{H}-{ }^{1} \mathrm{H} \operatorname{COSY}(\mathbf{A})$, key $\operatorname{HMBC}(\mathbf{A})$ and NOESY (B) correlations of compound 4 .

Figure S4. ${ }^{1} \mathrm{H}-{ }^{1} \mathrm{H} \operatorname{COSY}(\mathbf{A})$, key $\operatorname{HMBC}$ (A) and NOESY (B) correlations of compound 5 .

Figure S5. ${ }^{1} \mathrm{H}-{ }^{1} \mathrm{H} \operatorname{COSY}$ (A), key $\mathrm{HMBC}$ (A) and NOESY (B) correlations of compound 7.

Figure S6. ${ }^{1} \mathrm{H}-{ }^{1} \mathrm{H} \operatorname{COSY}(\mathbf{A})$, key $\operatorname{HMBC}$ (A) and NOESY (B) correlations of compound 9

Figure S7. ${ }^{1} \mathrm{H}-{ }^{1} \mathrm{H} \operatorname{COSY}(\mathbf{A})$, key $\mathrm{HMBC}$ (A) and NOESY (B) correlations of compound 10.

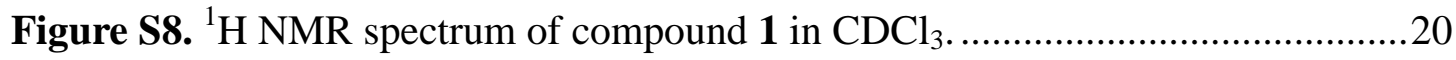

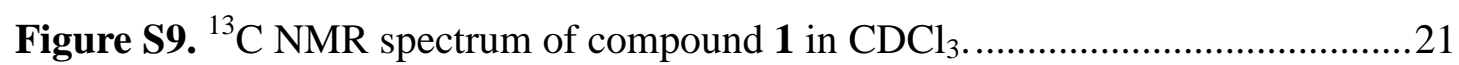

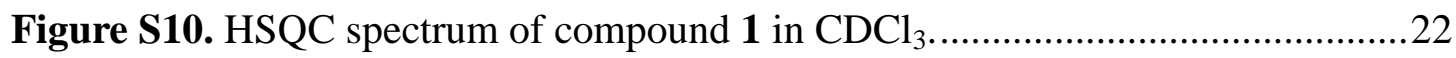

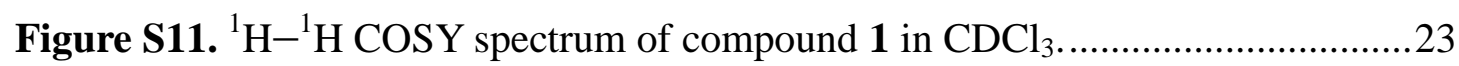

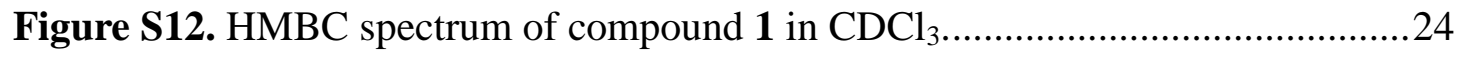

Figure S13. NOESY spectrum of compound 1 in $\mathrm{CDCl}_{3}$.................................25

Figure S14. (+)-ESIMS spectrum of compound 1............................................26

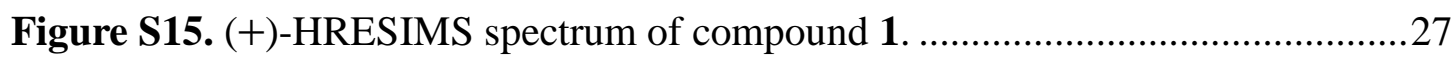

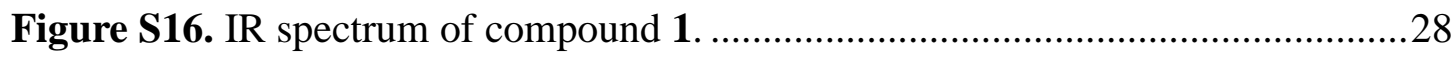

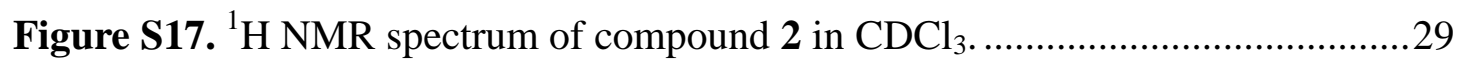

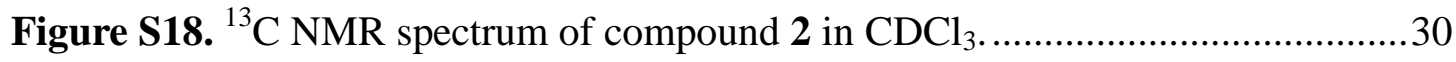

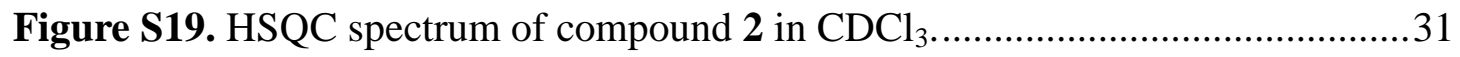

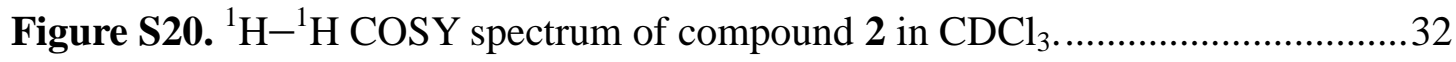

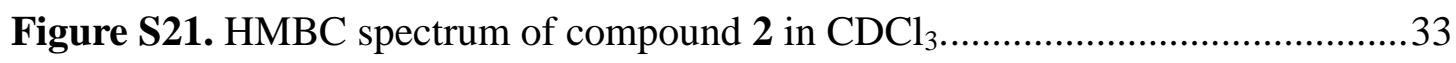

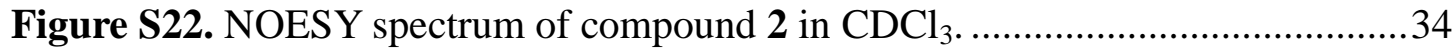

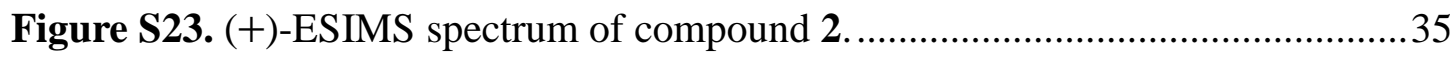




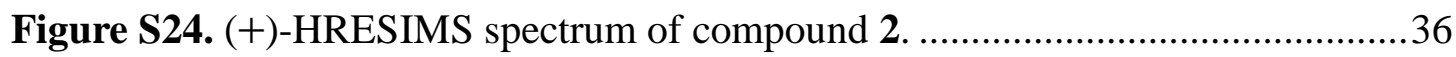

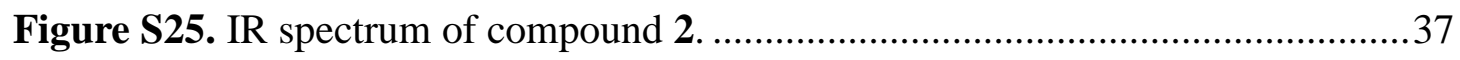

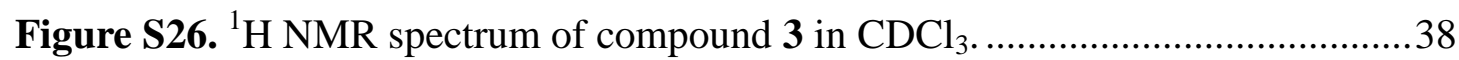

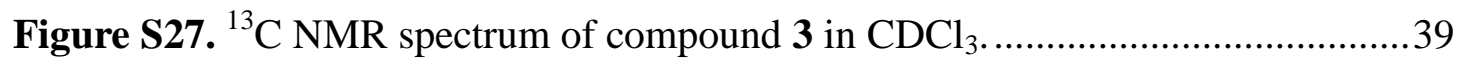

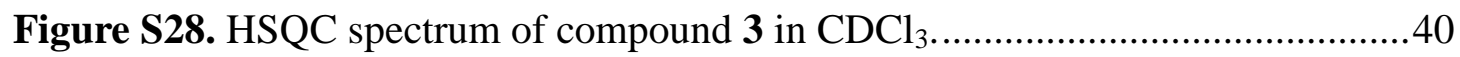

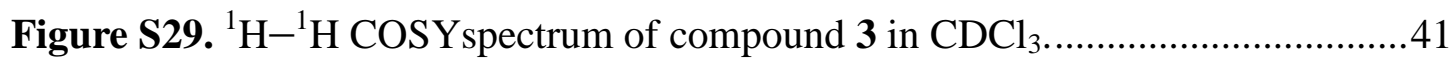

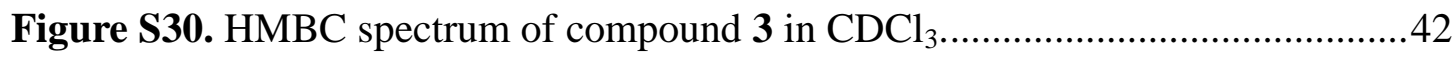

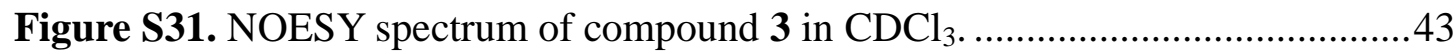

Figure S32. (+)-ESIMS spectrum of compound 3..............................................4

Figure S33. (+)-HRESIMS spectrum of compound 3..........................................45

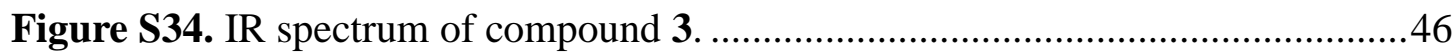

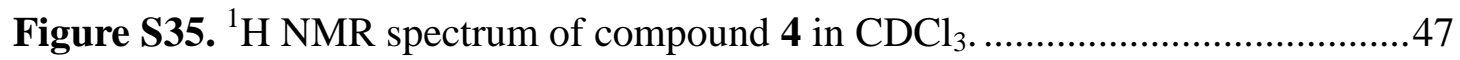

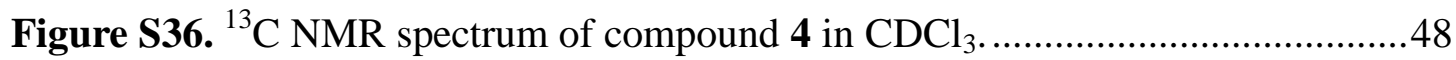

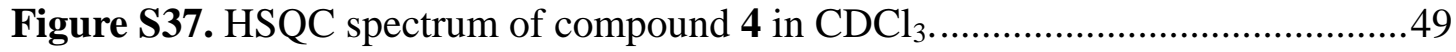

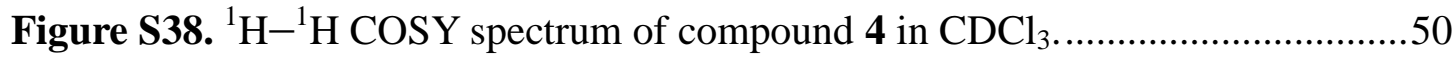

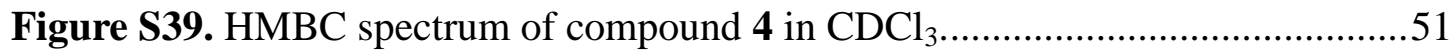

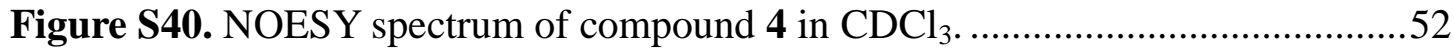

Figure S41. (+)-ESIMS spectrum of compound 4.............................................53

Figure S42. (-)-ESIMS spectrum of compound 4..........................................5

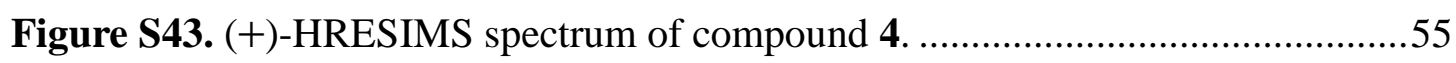

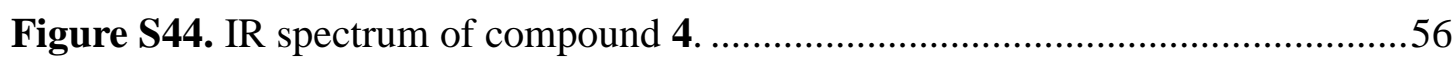

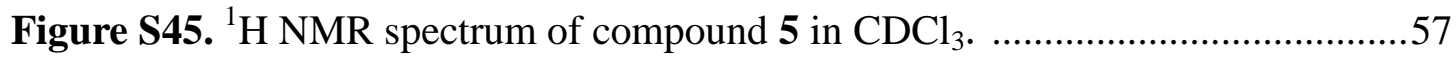

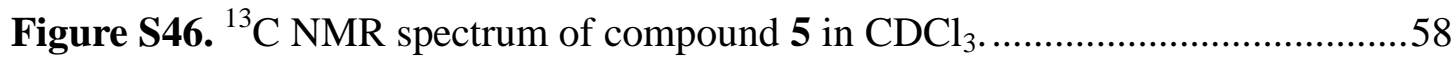

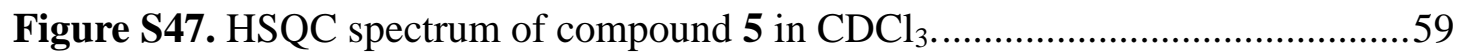

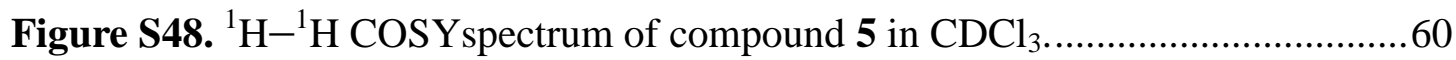

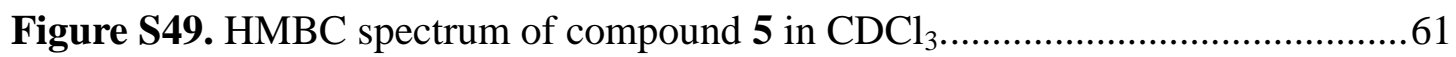

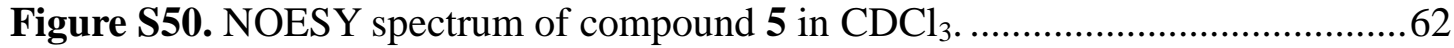


Figure S51. (+)-ESIMS spectrum of compound 5.

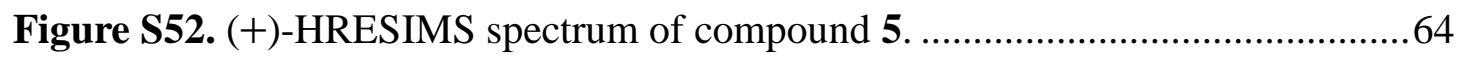

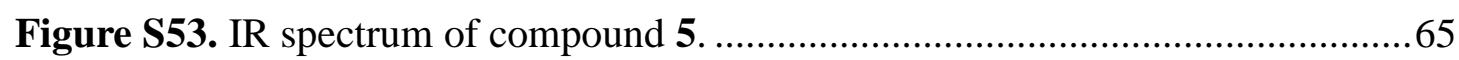

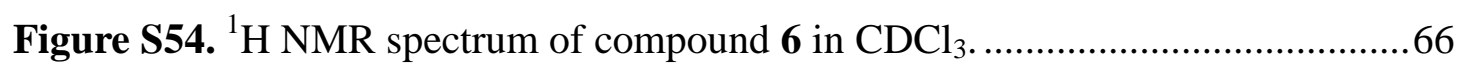

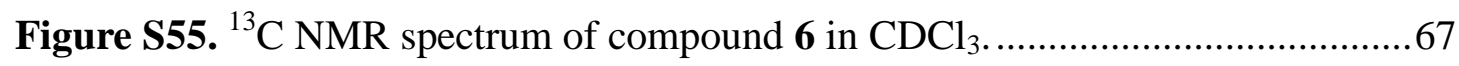

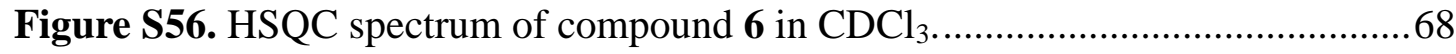

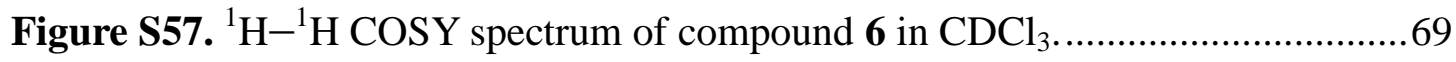

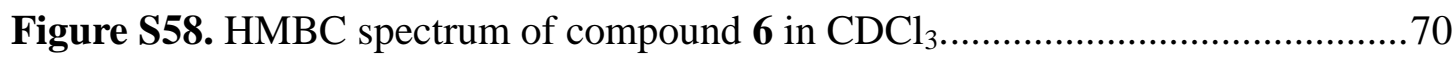

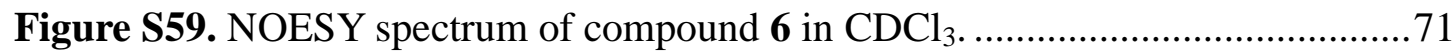

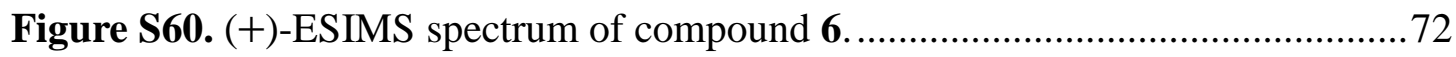

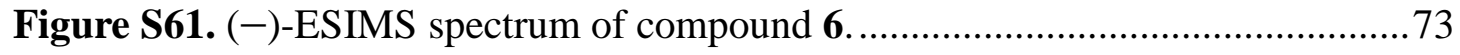

Figure S62. (+)-HRESIMS spectrum of compound 6........................................74

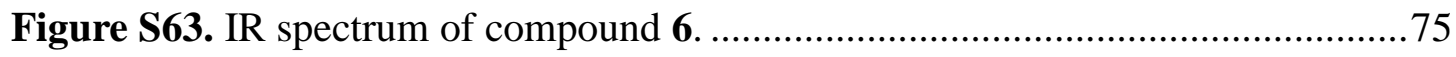

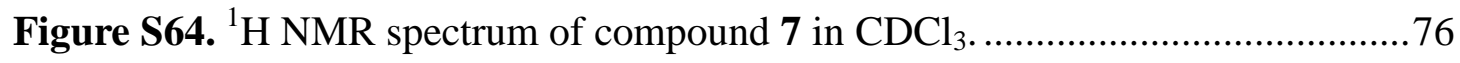

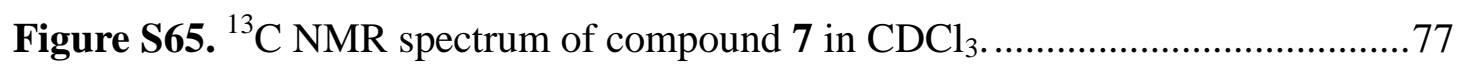

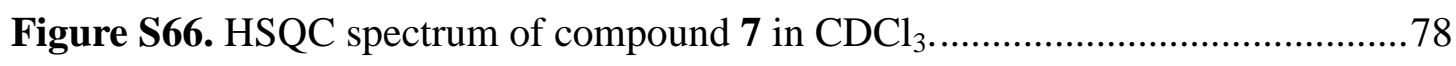

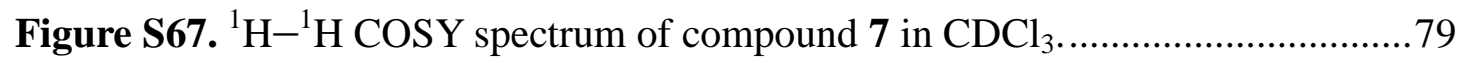

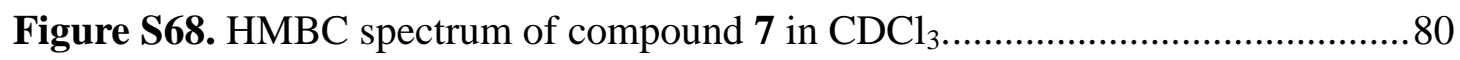

Figure S69. NOESY spectrum of compound 7 in $\mathrm{CDCl}_{3}$................................... 81

Figure S70. (+)-ESIMS spectrum of compound 7 ......................................... 82

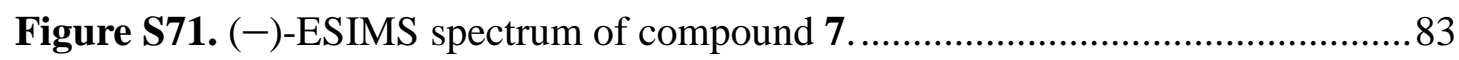

Figure S72. (+)-HRESIMS spectrum of compound 7 ......................................... 84

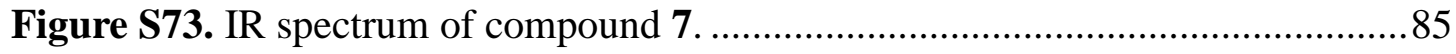

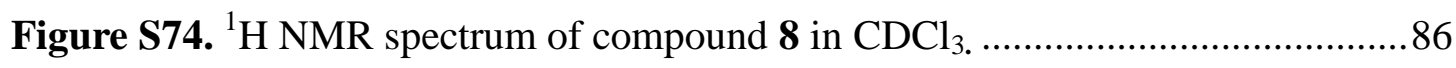

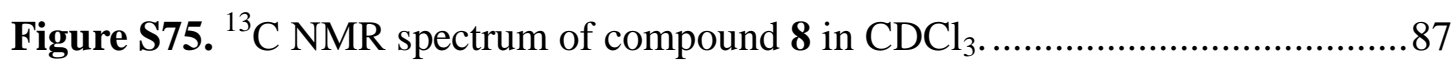

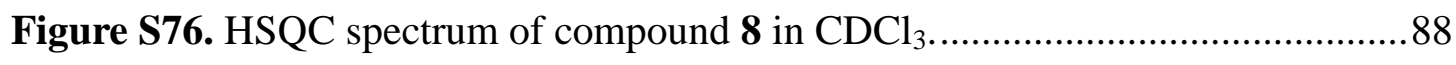




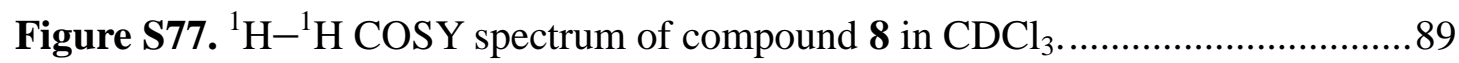

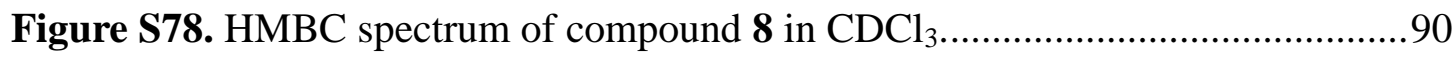

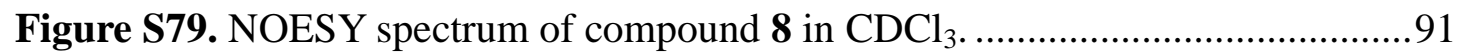

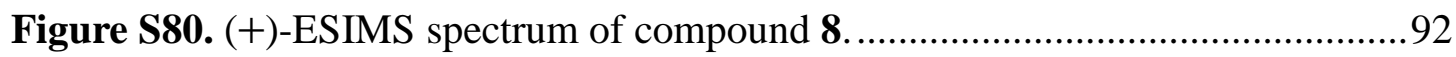

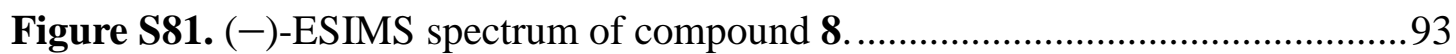

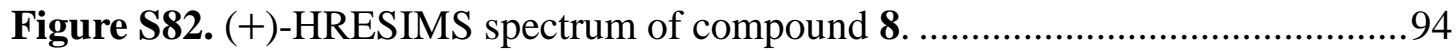

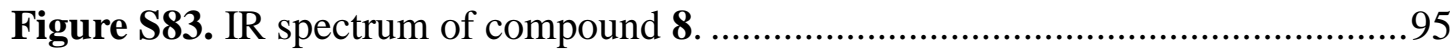

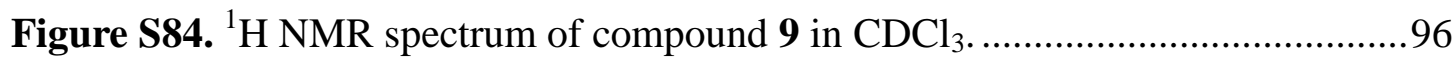

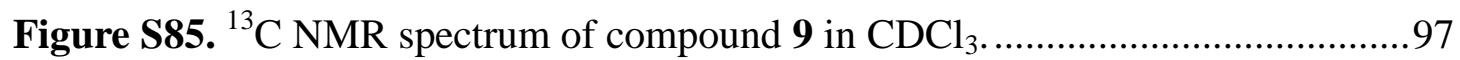

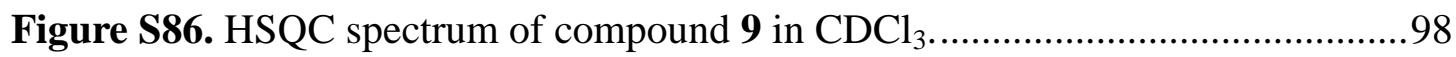

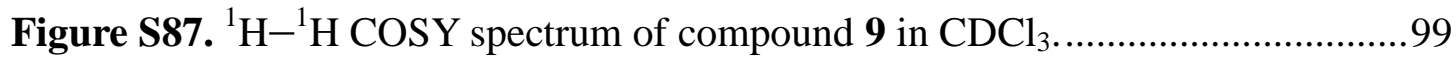

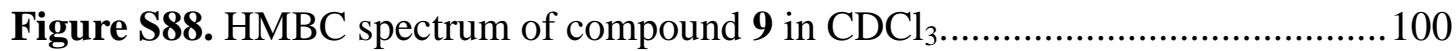

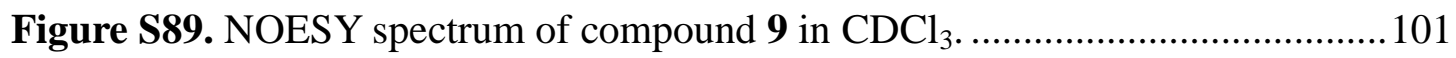

Figure S90. (+)-ESIMS spectrum of compound 9............................................ 102

Figure S91. (+)-HRESIMS spectrum of compound 9........................................ 103

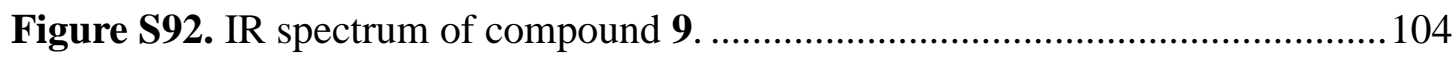

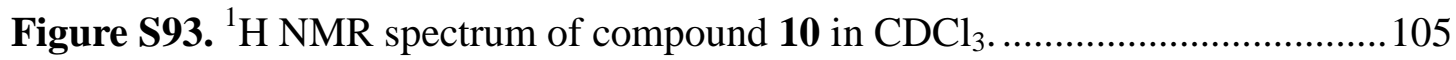

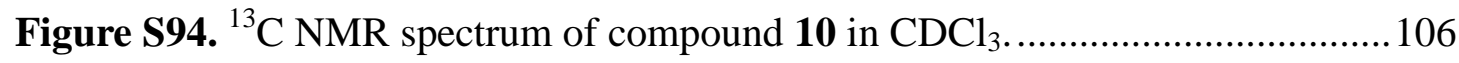

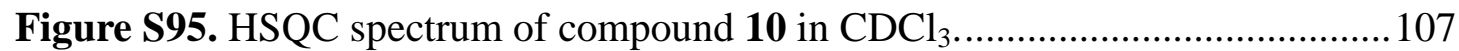

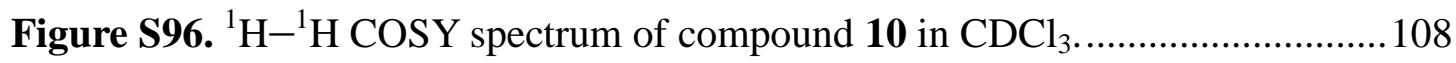

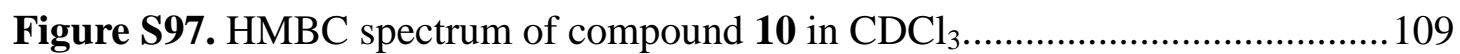

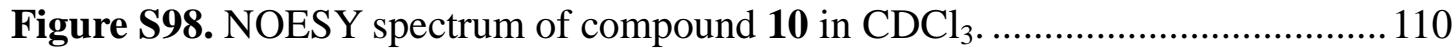

Figure S99. (+)-ESIMS spectrum of compound 10........................................ 111

Figure S100. (-)-ESIMS spectrum of compound 10 ........................................ 112

Figure S101. (+)-HRESIMS spectrum of compound 10 ................................... 113

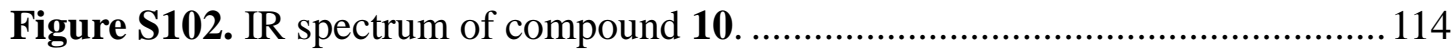




\section{General Experimental Procedures.}

Optical rotations were obtained on an Autopol VI automatic polarimeter at room temperature. UV spectra were acquired on a Shimadzu UV-2550 UV-visible spectrophotometer. IR spectra were measured on a PerkinElmer 577 spectrometer with $\mathrm{KBr}$ disks. NMR data were recorded on a Bruker AM-400 or AM-600 NMR spectrometers with tetramethylsilane as the internal reference. Single-crystal X-ray diffraction analyses were carried out on a Bruker D8 Venture diffractometer employing graphite monochromated $\mathrm{Ga} \mathrm{K} \alpha$ radiation. Melting points were measured on an SGM X-4 apparatus. LR-ESIMS were performed on a Bruker Daltonics Esquire 3000 plus and Thermo Fisher Finnigan LTQ. HR-ESIMS were measured on a Waters-Micromass Q-TOF Ultima Global mass spectrometer. Semipreparative HPLC purifications were conducted on a Waters 1525 binary pump system with a Waters 2489 UV detector and a YMC-Pack ODS-A column $(250 \times 10 \mathrm{~mm}, \mathrm{~S}-5 \mu \mathrm{m})$. D101-macroporous absorption resin (Shanghai Hualing Resin Co. Ltd.), MCI gel (CHP20P, 75-150 $\mu \mathrm{m}$, Mitsubishi Chemical Industries, Ltd.), Silica gel (300 - 400 mesh, Qingdao Marine Chemical Co. Ltd), $C_{18}$ reversed-phase silica gel (150 - 200 mesh, Merck), and Sephadex LH-20 gel (Amersham Biosciences) were used for column chromatography (CC). Precoated silica gel $\mathrm{GF}_{254}$ plates were used for TLC analyses. All solvents used for $\mathrm{CC}$ were of at least analytical grade (Shanghai Chemical Reagents Company, Ltd., Shanghai, People's Republic of China), and all solvents used for HPLC were of HPLC grade (J\&K Scientific Ltd.). 


\section{Plant Material.}

The twigs and leaves of Croton damayeshu (Y. T. Chang) were collected in Xishuangbanna, Yunan Province, People's Republic of China. The plant sample was identified by Prof. You-Kai Xu at Xishuangbanna Tropical Botanical Garden, Chinese Academy of Sciences. A voucher specimen has been deposited in our institute (accession number: Crody-2015-YN-1Y). 


\section{Extraction and Isolation.}

The powder of $C$. damayeshu $(6.5 \mathrm{~kg})$ was extracted with $95 \% \mathrm{EtOH}(3 \times 20 \mathrm{~L})$ at $25^{\circ} \mathrm{C}$ for 2 weeks to yield a syrup $(250 \mathrm{~g})$, which was first suspended in water $(3 \mathrm{~L})$ and then extracted with EtOAc. The EtOAc extract (125 g) was chromatographed over D101-macroporous absorption resin, washing with 30\%, 50\%, 80\%, and 95\% EtOH in $\mathrm{H}_{2} \mathrm{O}$ sequentially, to give fractions 1-4.

Fraction 3 (40 g) was separated on a column of MCI gel and eluted with gradients of $\mathrm{MeOH} / \mathrm{H}_{2} \mathrm{O}(30 \%$ to $100 \%)$ to give four parts, 3A-3D. Fraction 3B (17g) was subjected to a silica gel column, eluting with petroleum ether/acetone (20:1 to 1:5, v/v) to obtain subfractions 3B1 to 3B5. Fraction 3B3 was subjected to an RP-18 silica gel column $\left(\mathrm{MeOH} / \mathrm{H}_{2} \mathrm{O}, 40 \%\right.$ to $\left.100 \%\right)$ to give 3B3a-3B3i. After purification by semipreparative HPLC (eluted with $65 \%, 65 \%$, and $70 \% \mathrm{CH}_{3} \mathrm{CN} / \mathrm{H}_{2} \mathrm{O}$, respectively), fractions 3B3a, 3B3b, and 3B3d yielded compounds $\mathbf{1 0}(1 \mathrm{mg}, 0.000015 \%$ yield of the dried plant material), 11 (10 $\mathrm{mg}, 0.000154 \%$ yield of the dried plant material), and 8 (10 mg, 0.000154\% yield of the dried plant material), respectively. Fraction 3B3e was fractionated using silica gel $\mathrm{CC}$ with petroleum ether/ $\mathrm{CHCl}_{3}$ gradient (3:1 to 1:5) to afford five parts, $3 \mathrm{~B} 3 \mathrm{e} 1-3 \mathrm{~B} 3 \mathrm{e} 5$. Fraction $3 \mathrm{~B} 3 \mathrm{e} 3$ and $3 \mathrm{~B} 3 \mathrm{e} 5$ were separated by semipreparative HPLC (65\% and 65\% $\left.\mathrm{CH}_{3} \mathrm{CN} / \mathrm{H}_{2} \mathrm{O}\right)$ to afford compounds 12 (5 mg, $0.000077 \%$ yield of the dried plant material) and 6 ( $2 \mathrm{mg}, 0.000031 \%$ yield of the dried plant material), respectively. Similarly, fraction 3B3f yielded compound 15 (5 $\mathrm{mg}, 0.000077 \%$ yield of the dried plant material) and fraction 3B3g yielded compounds 4 (3 mg, 0.000046\% yield of the dried plant material) and 13 (3 mg, $0.000046 \%$ yield of the dried plant material). Fraction 3B2 was fractionated over an RP-18 silica gel column using $\mathrm{MeOH} / \mathrm{H}_{2} \mathrm{O}(50 \%$ to $100 \%)$ as the mobile phase, to give 3B2a-3B2e. Fraction 3B2e was subjected to a silica gel column and eluted with a petroleum ether/acetone gradient $(10: 1$ to $1: 5, \mathrm{v} / \mathrm{v})$ to give two parts, $3 \mathrm{~B} 2 \mathrm{e} 1$ and 3B2e2. Fraction 3B2e1 was further separated by semipreparative HPLC (70\% $\left.\mathrm{CH}_{3} \mathrm{CN} / \mathrm{H}_{2} \mathrm{O}\right)$ to yield compounds $3(15 \mathrm{mg}, 0.000231 \%$ yield of the dried plant 
material) and 9 (4 mg, 0.000062\% yield of the dried plant material). In similar procedures, fraction 3C (18g) yielded compounds $5(1 \mathrm{mg}, 0.000015 \%$ yield of the dried plant material) and $14(1 \mathrm{mg}, 0.000015 \%$ yield of the dried plant material). Fraction 2 (25 g) was separated over a silica gel column using a petroleum ether/acetone gradient $(20: 1$ to $1: 5, \mathrm{v} / \mathrm{v})$ to yield fractions $2 \mathrm{~A}-2 \mathrm{E}$. According to the similar procedures for fractions 3B and 3C, fractions $2 \mathrm{~B}(200 \mathrm{mg}), 2 \mathrm{C}(1 \mathrm{~g})$, and 2D $(2 \mathrm{~g})$ yielded compounds 1 ( $2 \mathrm{mg}, 0.000031 \%$ yield of the dried plant material), 2 (10 $\mathrm{mg}, 0.000154 \%$ yield of the dried plant material), and 7 (10 mg, 0.000154\% yield of the dried plant material), respectively. 


\section{X-ray Crystallographic Analysis}

Crodamoid A (1) and crodamoid $\mathrm{H}(\mathbf{8})$ were both crystallized from $\mathrm{MeOH}$ solvent at room temperature. crodamoid $\mathrm{F}(\mathbf{6})$ was crystallized from $\mathrm{EtOH}$ at room temperature. The crystal data were collected on a Bruker D8 Venture diffractometer employing graphite monochromated Ga-K $\alpha$ radiation $(\lambda=1.34139 \AA)$ at 170.01 169.97 and $169.99 \mathrm{~K}$ using Olex $2^{1}$, respectively. The structures were solved with ShelXT ${ }^{2}$ structure solution program using Intrinsic Phasing and refined with the ShelXL ${ }^{3}$ refinement package using Least Squares minimisation. A copy of the data can be obtained free of charge on application to the CCDC, 12 Union Road, Cambridge CB2 1EZ, UK [tel: (+44) 1223-336-408: fax: (+44) 1223-336-033; email: deposit0@ccdc.cam.ac.uk].

\section{References}

(1) Dolomanov, O.V., Bourhis, L.J., Gildea, R.J, Howard, J.A.K. \& Puschmann, H. J. Appl. Cryst. 2009, 42, 339-341.

(2) Sheldrick, G.M. Acta Cryst. 2015, A71, 3-8.

(3) Sheldrick, G.M. Acta Cryst. 2015, C71, 3-8. 


\section{Cytotoxicity Assessment.}

All the isolates except the insufficient compounds $\mathbf{5}$, and $\mathbf{1 4}$ were assessed for their vitro cytotoxic activities against A549 and HL-60 cell lines with the CCK-8 method. The positive control was adriamycin with $>98 \%$ purity (Meilun, Dalian, China). Briefly, $90 \mu \mathrm{L}$ per well of the cells at logarithmic growth stage were plated in 96-well plates. After overnight culture, the cells were grown with various concentrations of tested compounds for $72 \mathrm{~h}$, and each concentration is in triplicate. $10 \mu \mathrm{L}$ of CCK-8 was added to each well and the cells were incubated for 4 hours. The optical density per well was read on SpectraMax 190 microplate reader at a wavelength of $450 \mathrm{~nm}$. The $\mathrm{IC}_{50}$ values from two separate assay are expressed in the mean \pm SD. 
Table S1. X-ray crystallographic data for compound $\mathbf{1}^{a}$.

\begin{tabular}{|c|c|c|}
\hline Empirical formula & \multicolumn{2}{|l|}{$\mathrm{C}_{29} \mathrm{H}_{42} \mathrm{O}_{7}$} \\
\hline Formula weight & \multicolumn{2}{|l|}{502.62} \\
\hline Temperature & \multicolumn{2}{|l|}{$170.01 \mathrm{~K}$} \\
\hline Wavelength & \multicolumn{2}{|l|}{$1.34139 \AA$} \\
\hline Crystal system & \multicolumn{2}{|l|}{ Monoclinic } \\
\hline Space group & \multicolumn{2}{|l|}{ P 1211} \\
\hline \multirow[t]{3}{*}{ Unit cell dimensions } & $\mathrm{a}=7.2498(2) \AA$ & $\alpha=90^{\circ}$. \\
\hline & $\mathrm{b}=12.1481(3) \AA$ & $\beta=97.2480(10)^{\circ}$. \\
\hline & $c=15.2910(3) \AA$ & $\gamma=90^{\circ}$ \\
\hline Volume & \multicolumn{2}{|l|}{$1335.94(6) \AA^{3}$} \\
\hline $\mathrm{Z}$ & \multicolumn{2}{|l|}{2} \\
\hline Density (calculated) & \multicolumn{2}{|l|}{$1.249 \mathrm{Mg} / \mathrm{m}^{3}$} \\
\hline Absorption coefficient & \multicolumn{2}{|l|}{$0.458 \mathrm{~mm}^{-1}$} \\
\hline $\mathrm{F}(000)$ & \multicolumn{2}{|l|}{544} \\
\hline Crystal size & \multicolumn{2}{|c|}{$0.15 \times 0.1 \times 0.08 \mathrm{~mm}^{3}$} \\
\hline Theta range for data collection & \multicolumn{2}{|l|}{5.351 to $54.935^{\circ}$. } \\
\hline Index ranges & \multicolumn{2}{|c|}{$-8<=\mathrm{h}<=8,-14<=\mathrm{k}<=14,-18<=\mathrm{l}<=18$} \\
\hline Reflections collected & \multicolumn{2}{|l|}{16571} \\
\hline Independent reflections & \multicolumn{2}{|c|}{$5052[\mathrm{R}($ int $)=0.0357]$} \\
\hline Completeness to theta $=53.594^{\circ}$ & \multicolumn{2}{|l|}{$99.7 \%$} \\
\hline Absorption correction & \multicolumn{2}{|c|}{ Semi-empirical from equivalents } \\
\hline Max. and min. transmission & \multicolumn{2}{|l|}{0.7508 and 0.6325} \\
\hline Refinement method & \multicolumn{2}{|c|}{ Full-matrix least-squares on $\mathrm{F}^{2}$} \\
\hline Data / restraints / parameters & \multicolumn{2}{|l|}{$5052 / 1 / 334$} \\
\hline Goodness-of-fit on $\mathrm{F}^{2}$ & \multicolumn{2}{|l|}{1.066} \\
\hline Final R indices $[\mathrm{I}>2 \operatorname{sigma}(\mathrm{I})]$ & \multicolumn{2}{|c|}{$\mathrm{R} 1=0.0552, \mathrm{wR} 2=0.1505$} \\
\hline $\mathrm{R}$ indices (all data) & \multicolumn{2}{|c|}{$\mathrm{R} 1=0.0596, \mathrm{wR} 2=0.1561$} \\
\hline Absolute structure parameter & \multicolumn{2}{|l|}{$-0.10(9)$} \\
\hline Extinction coefficient & \multicolumn{2}{|l|}{$\mathrm{n} / \mathrm{a}$} \\
\hline Largest diff. peak and hole & \multicolumn{2}{|c|}{1.344 and -0.439 e. $\AA^{-3}$} \\
\hline
\end{tabular}

${ }^{a}$ Crystals of 1 were obtained from $\mathrm{MeOH}$. 
Table S2. X-ray crystallographic data for compound $6^{a}$.

\begin{tabular}{|c|c|c|}
\hline Empirical formula & \multicolumn{2}{|l|}{$\mathrm{C}_{30} \mathrm{H}_{42} \mathrm{O}_{8}$} \\
\hline Formula weight & \multicolumn{2}{|l|}{530.63} \\
\hline Temperature & \multicolumn{2}{|l|}{$169.99 \mathrm{~K}$} \\
\hline Wavelength & \multicolumn{2}{|l|}{$1.34139 \AA$} \\
\hline Crystal system & \multicolumn{2}{|l|}{ Orthorhombic } \\
\hline Space group & \multicolumn{2}{|l|}{ P 212121} \\
\hline \multirow[t]{3}{*}{ Unit cell dimensions } & $a=26.368(5) \AA$ & $\alpha=90^{\circ}$ \\
\hline & $\mathrm{b}=8.2584(15) \AA$ & $\beta=90^{\circ}$ \\
\hline & $c=14.127(3) \AA$ & $\gamma=90^{\circ}$ \\
\hline Volume & \multicolumn{2}{|l|}{$3076.3(10) \AA^{3}$} \\
\hline $\mathrm{Z}$ & \multicolumn{2}{|l|}{4} \\
\hline Density (calculated) & \multicolumn{2}{|l|}{$1.146 \mathrm{Mg} / \mathrm{m}^{3}$} \\
\hline Absorption coefficient & \multicolumn{2}{|l|}{$0.431 \mathrm{~mm}^{-1}$} \\
\hline $\mathrm{F}(000)$ & \multicolumn{2}{|l|}{1144} \\
\hline Crystal size & \multicolumn{2}{|c|}{$0.1 \times 0.02 \times 0.01 \mathrm{~mm}^{3}$} \\
\hline Theta range for data collection & \multicolumn{2}{|l|}{3.990 to $55.064^{\circ}$. } \\
\hline Index ranges & \multicolumn{2}{|c|}{$-32<=\mathrm{h}<=32,-9<=\mathrm{k}<=10,-17<=\mathrm{l}<=17$} \\
\hline Reflections collected & \multicolumn{2}{|l|}{19203} \\
\hline Independent reflections & \multicolumn{2}{|c|}{$5691[\mathrm{R}(\mathrm{int})=0.1361]$} \\
\hline Completeness to theta $=53.594^{\circ}$ & \multicolumn{2}{|l|}{$98.0 \%$} \\
\hline Absorption correction & \multicolumn{2}{|c|}{ Semi-empirical from equivalents } \\
\hline Max. and min. transmission & \multicolumn{2}{|l|}{0.7508 and 0.3863} \\
\hline Refinement method & \multicolumn{2}{|c|}{ Full-matrix least-squares on $\mathrm{F}^{2}$} \\
\hline Data / restraints / parameters & \multicolumn{2}{|l|}{$5691 / 1 / 353$} \\
\hline Goodness-of-fit on $\mathrm{F}^{2}$ & \multicolumn{2}{|l|}{0.958} \\
\hline Final $\mathrm{R}$ indices [I>2sigma(I)] & \multicolumn{2}{|c|}{$\mathrm{R} 1=0.0973, \mathrm{wR} 2=0.2289$} \\
\hline $\mathrm{R}$ indices (all data) & \multicolumn{2}{|c|}{$\mathrm{R} 1=0.1981, \mathrm{wR} 2=0.3019$} \\
\hline Absolute structure parameter & \multicolumn{2}{|l|}{$-0.1(5)$} \\
\hline Extinction coefficient & \multicolumn{2}{|l|}{$\mathrm{n} / \mathrm{a}$} \\
\hline Largest diff. peak and hole & \multicolumn{2}{|c|}{0.457 and -0.368 e. $\AA^{-3}$} \\
\hline
\end{tabular}

${ }^{a}$ Crystals of 6 were obtained from $\mathrm{EtOH}$. 
Table S3. X-ray crystallographic data for compound $\mathbf{8}^{a}$.

\begin{tabular}{|c|c|c|}
\hline Empirical formula & \multicolumn{2}{|l|}{$\mathrm{C}_{25} \mathrm{H}_{34} \mathrm{O}_{6}$} \\
\hline Formula weight & \multicolumn{2}{|l|}{430.52} \\
\hline Temperature & \multicolumn{2}{|l|}{$169.97 \mathrm{~K}$} \\
\hline Wavelength & \multicolumn{2}{|l|}{$1.34139 \AA$} \\
\hline Crystal system & \multicolumn{2}{|l|}{ Orthorhombic } \\
\hline Space group & \multicolumn{2}{|l|}{ P 212121} \\
\hline \multirow[t]{3}{*}{ Unit cell dimensions } & $a=9.4458(2) \AA$ & $\alpha=90^{\circ}$ \\
\hline & $\mathrm{b}=9.5339(2) \AA$ & $\beta=90^{\circ}$ \\
\hline & $\mathrm{c}=24.4990(5) \AA$ & $\gamma=90^{\circ}$ \\
\hline Volume & \multicolumn{2}{|l|}{$2206.27(8) \AA^{3}$} \\
\hline $\mathrm{Z}$ & \multicolumn{2}{|l|}{4} \\
\hline Density (calculated) & \multicolumn{2}{|l|}{$1.296 \mathrm{Mg} / \mathrm{m}^{3}$} \\
\hline Absorption coefficient & \multicolumn{2}{|l|}{$0.477 \mathrm{~mm}^{-1}$} \\
\hline $\mathrm{F}(000)$ & \multicolumn{2}{|l|}{928} \\
\hline Crystal size & \multicolumn{2}{|c|}{$0.12 \times 0.05 \times 0.03 \mathrm{~mm}^{3}$} \\
\hline Theta range for data collection & \multicolumn{2}{|l|}{7.433 to $54.921^{\circ}$. } \\
\hline Index ranges & \multicolumn{2}{|c|}{$-11<=\mathrm{h}<=11,-11<=\mathrm{k}<=10,-29<=1<=29$} \\
\hline Reflections collected & \multicolumn{2}{|l|}{23672} \\
\hline Independent reflections & \multicolumn{2}{|c|}{$4139[\mathrm{R}($ int $)=0.0323]$} \\
\hline Completeness to theta $=53.594^{\circ}$ & \multicolumn{2}{|l|}{$98.2 \%$} \\
\hline Absorption correction & \multicolumn{2}{|c|}{ Semi-empirical from equivalents } \\
\hline Max. and min. transmission & \multicolumn{2}{|l|}{0.7508 and 0.6359} \\
\hline Refinement method & \multicolumn{2}{|c|}{ Full-matrix least-squares on $\mathrm{F}^{2}$} \\
\hline Data / restraints / parameters & \multicolumn{2}{|l|}{$4139 / 0 / 288$} \\
\hline Goodness-of-fit on $\mathrm{F}^{2}$ & \multicolumn{2}{|l|}{1.094} \\
\hline Final $R$ indices $[\mathrm{I}>2 \operatorname{sigma}(\mathrm{I})]$ & \multicolumn{2}{|c|}{$\mathrm{R} 1=0.0384, \mathrm{wR} 2=0.0992$} \\
\hline $\mathrm{R}$ indices (all data) & \multicolumn{2}{|c|}{$\mathrm{R} 1=0.0387, \mathrm{wR} 2=0.0995$} \\
\hline Absolute structure parameter & \multicolumn{2}{|l|}{$0.01(4)$} \\
\hline Extinction coefficient & \multicolumn{2}{|l|}{$\mathrm{n} / \mathrm{a}$} \\
\hline Largest diff. peak and hole & \multicolumn{2}{|c|}{0.783 and -0.257 e. $\AA^{-3}$} \\
\hline
\end{tabular}

${ }^{a}$ Crystals of $\mathbf{8}$ were obtained from $\mathrm{MeOH}$. 


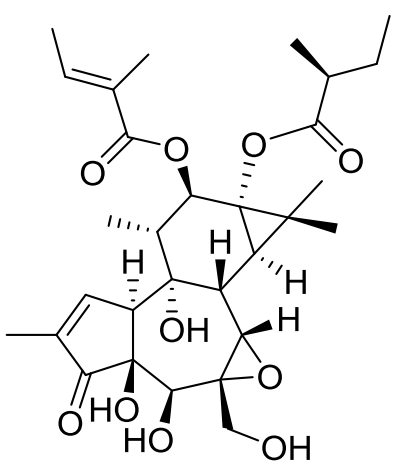

tigilanol tiglate

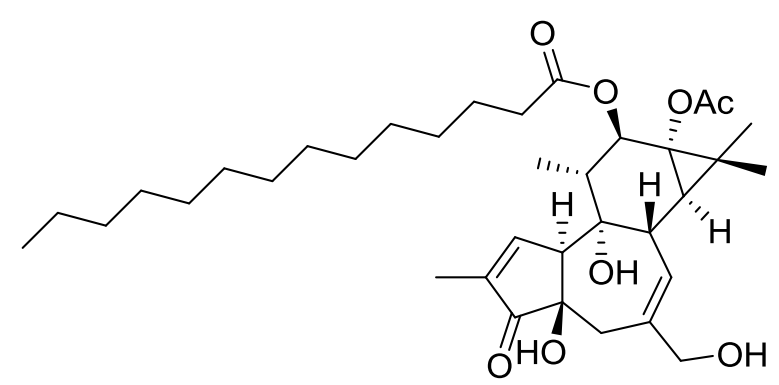

PMA

Figure S0. The structure of the tigilanol tiglate and phorbol

12-myristate-13-acetate (PMA)

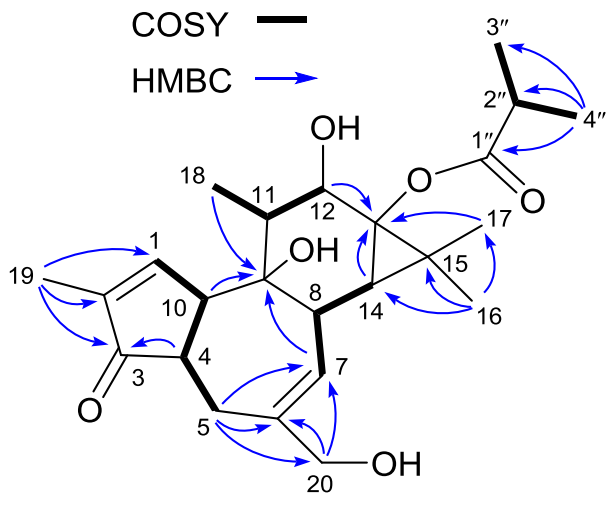

A

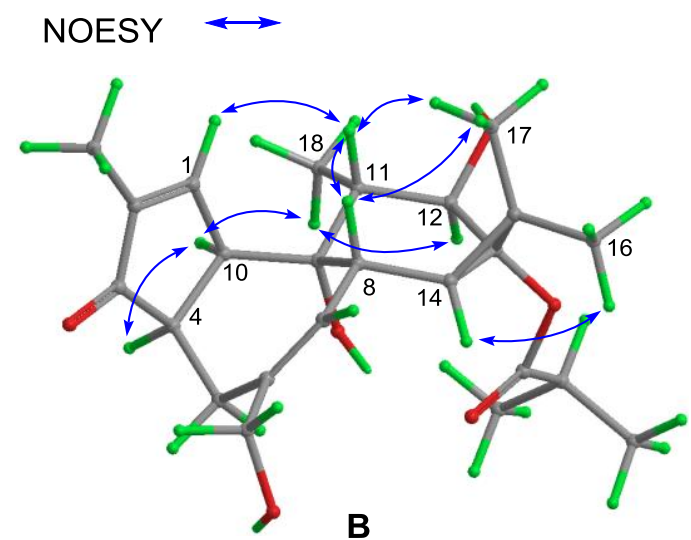

Figure S1. ${ }^{1} \mathrm{H}-{ }^{1} \mathrm{H} \operatorname{COSY}(\mathbf{A})$, key HMBC (A) and NOESY (B) correlations of compound $\mathbf{2}$. 

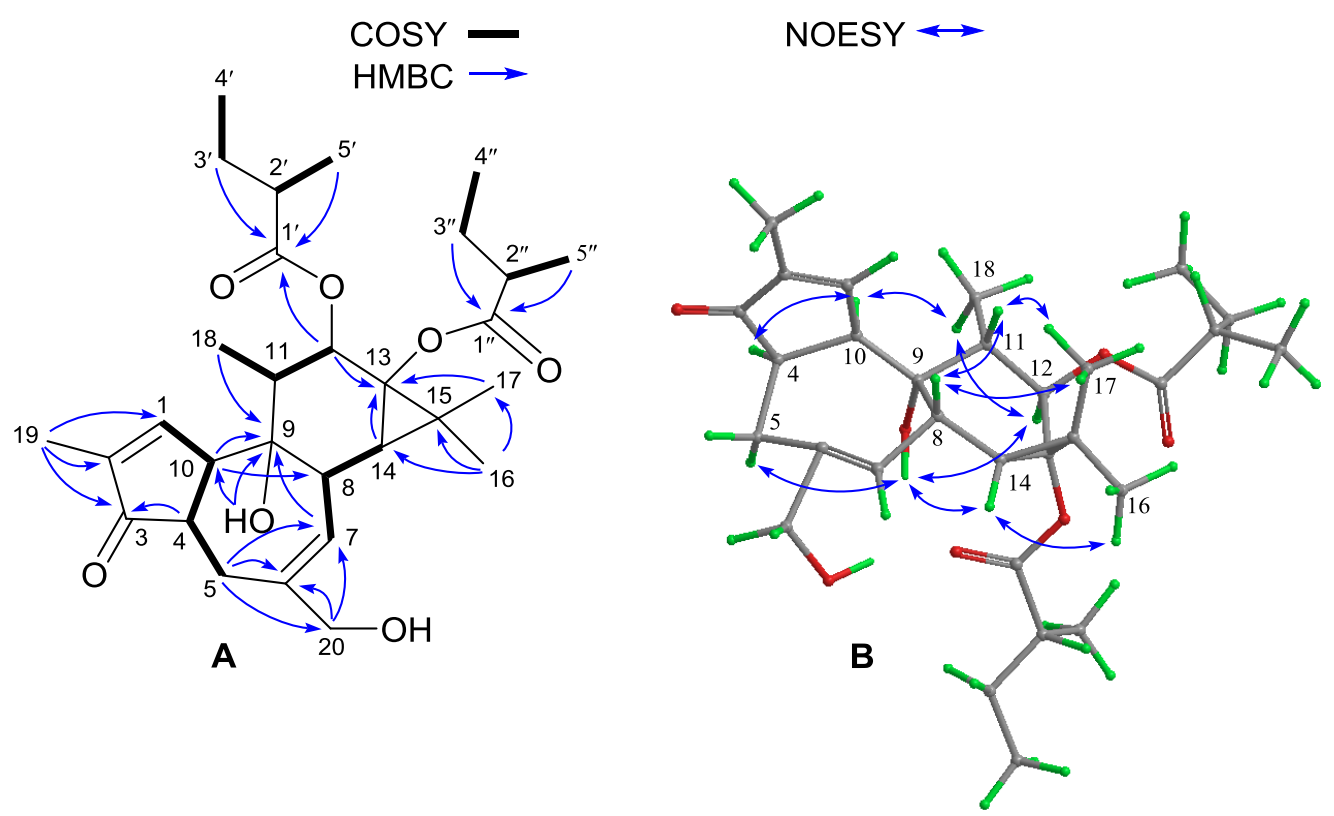

Figure S2. ${ }^{1} \mathrm{H}-{ }^{1} \mathrm{H} \operatorname{COSY}(\mathbf{A})$, key HMBC (A) and NOESY (B) correlations of compound $\mathbf{3}$.
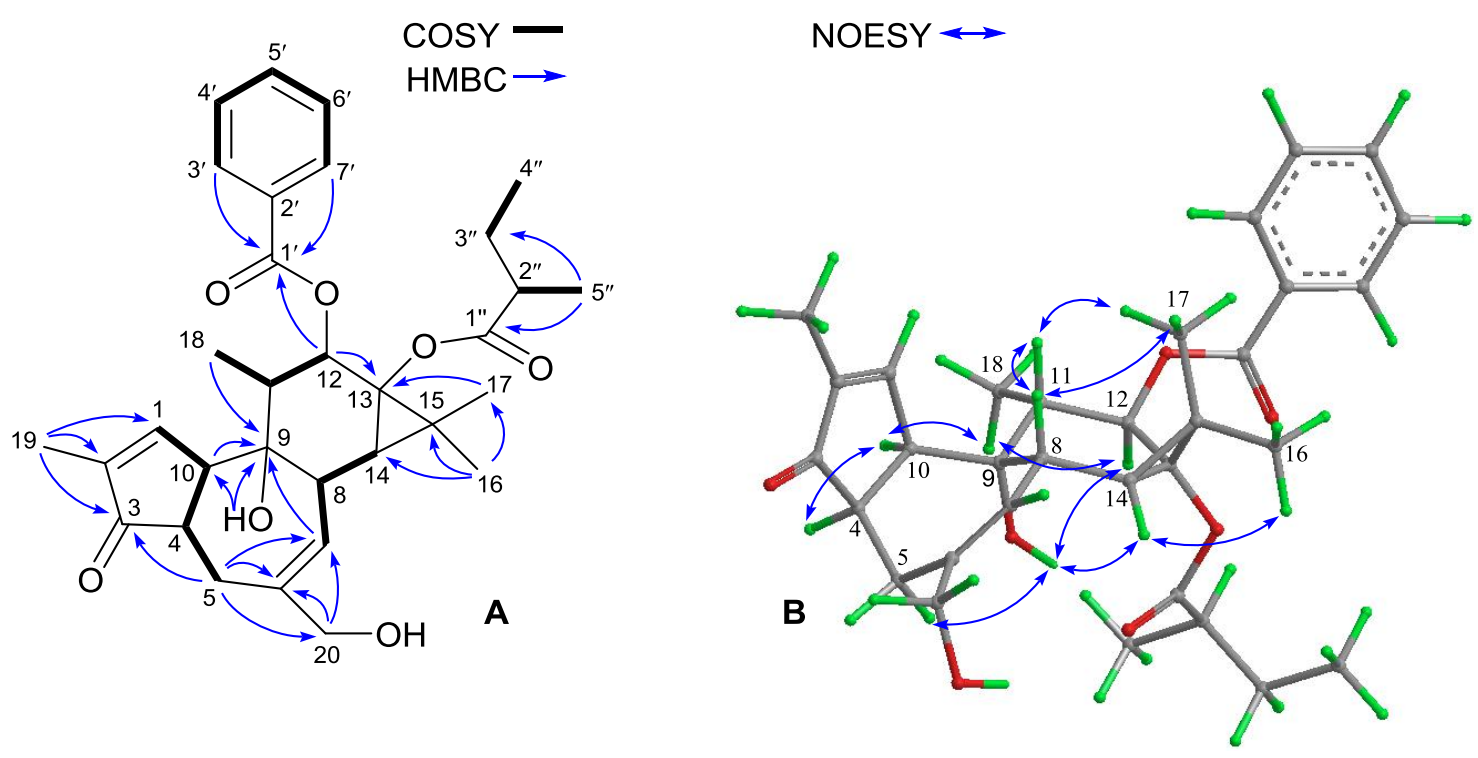

Figure S3. ${ }^{1} \mathrm{H}-{ }^{1} \mathrm{H} \operatorname{COSY}(\mathbf{A})$, key HMBC (A) and NOESY (B) correlations of compound 4 . 


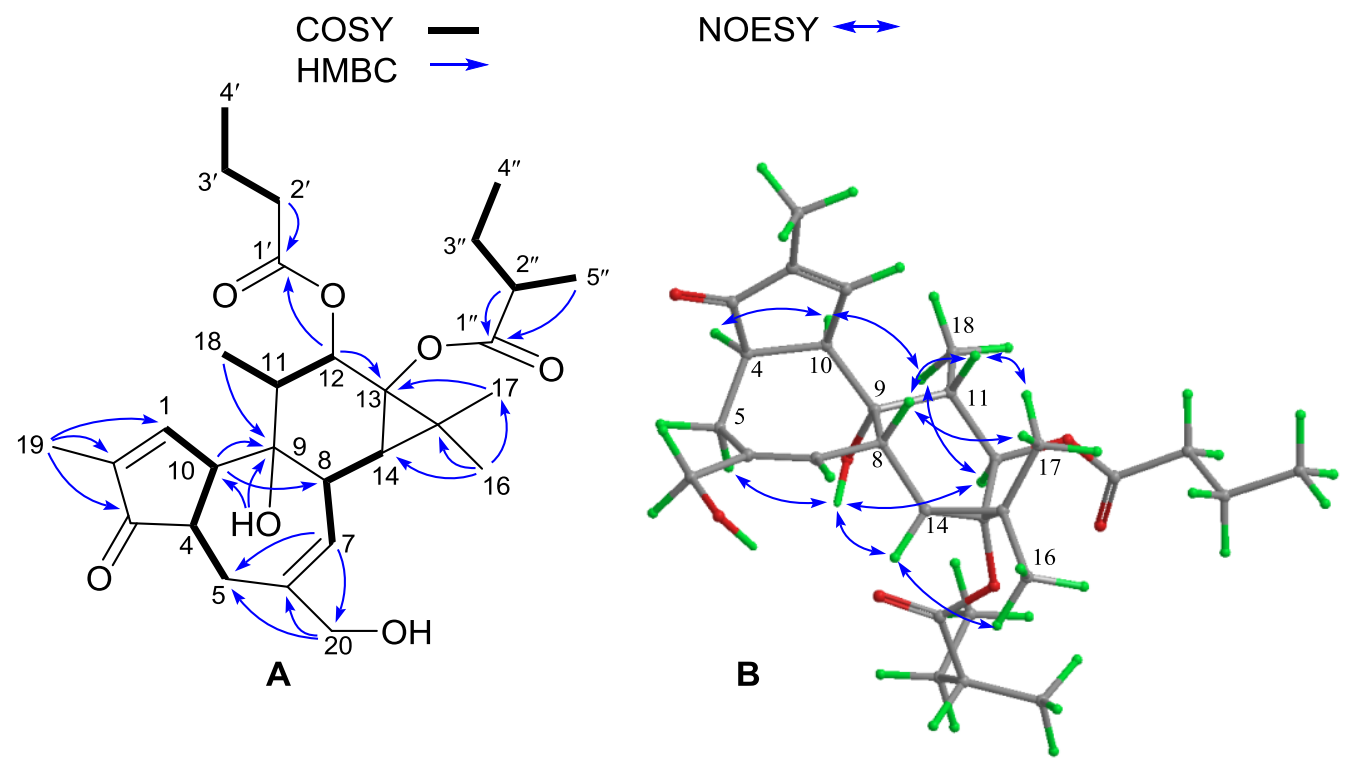

Figure S4. ${ }^{1} \mathrm{H}-{ }^{1} \mathrm{H}$ COSY (A), key $\operatorname{HMBC}$ (A) and NOESY (B) correlations of compound $\mathbf{5}$. 


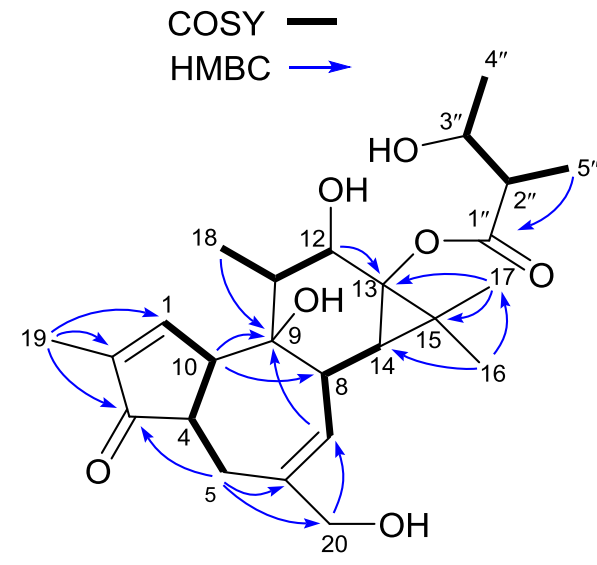

A

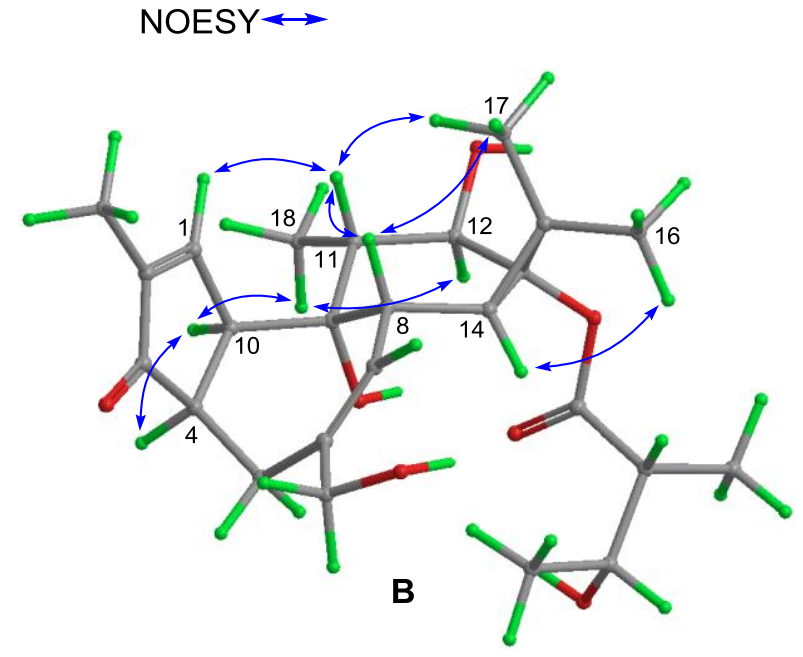

B

Figure S5. ${ }^{1} \mathrm{H}-{ }^{1} \mathrm{H} \operatorname{COSY}(\mathbf{A})$, key $\operatorname{HMBC}(\mathbf{A})$ and NOESY (B) correlations of compound 7.
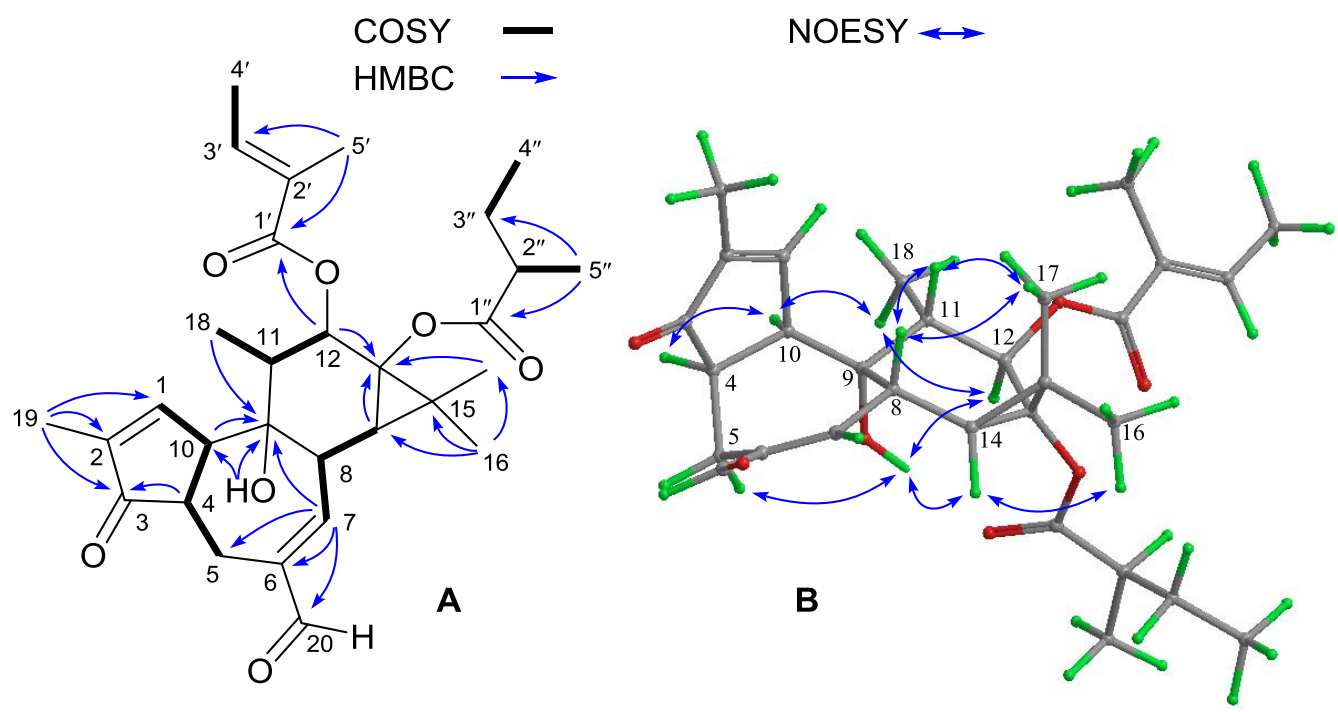

Figure S6. ${ }^{1} \mathrm{H}-{ }^{1} \mathrm{H} \operatorname{COSY}(\mathbf{A})$, key $\operatorname{HMBC}(\mathbf{A})$ and NOESY (B) correlations of compound 9 . 


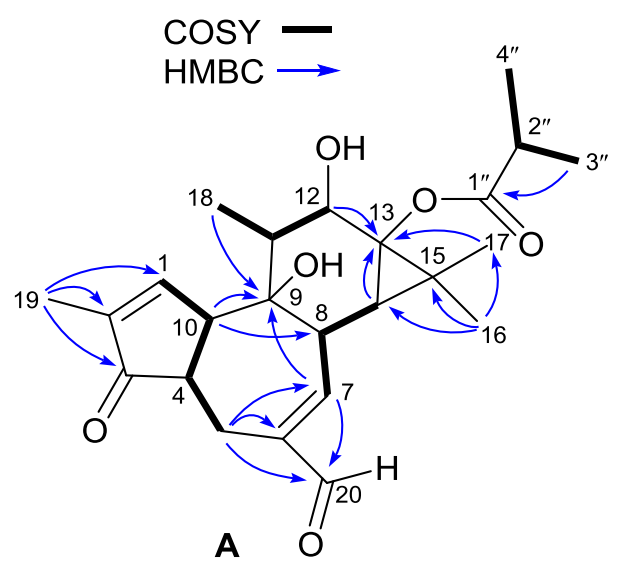

NOESY $\longleftrightarrow$

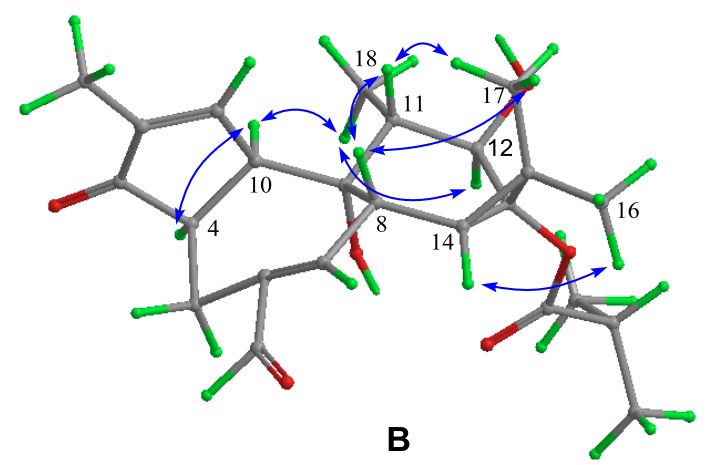

Figure S7. ${ }^{1} \mathrm{H}-{ }^{1} \mathrm{H} \operatorname{COSY}(\mathbf{A})$, key HMBC (A) and NOESY (B) correlations of compound $\mathbf{1 0 .}$ 
Figure S8. ${ }^{1} \mathrm{H}$ NMR spectrum of compound $\mathbf{1}$ in $\mathrm{CDCl}_{3}$.

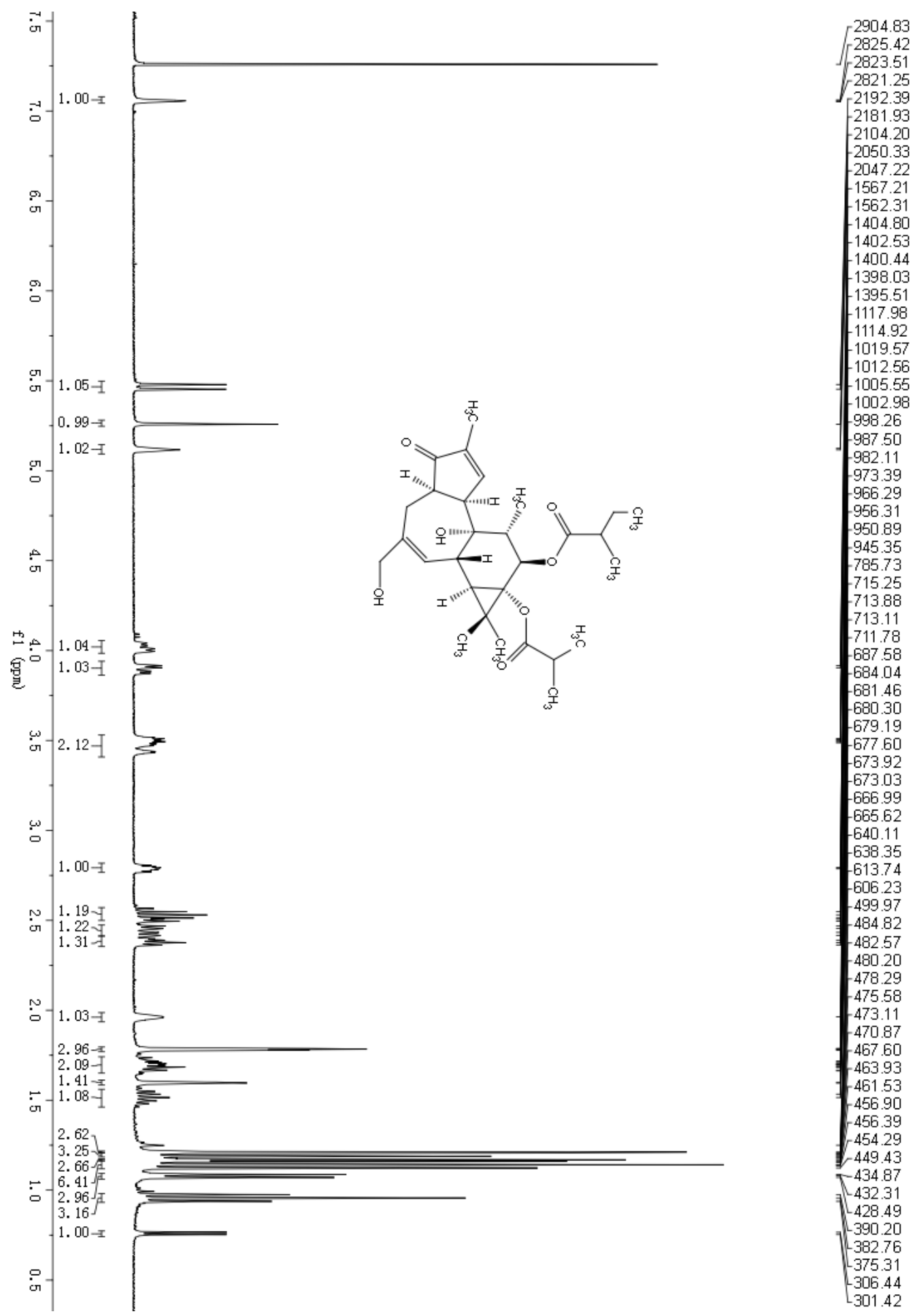


Figure S9. ${ }^{13} \mathrm{C}$ NMR spectrum of compound $\mathbf{1}$ in $\mathrm{CDCl}_{3}$.

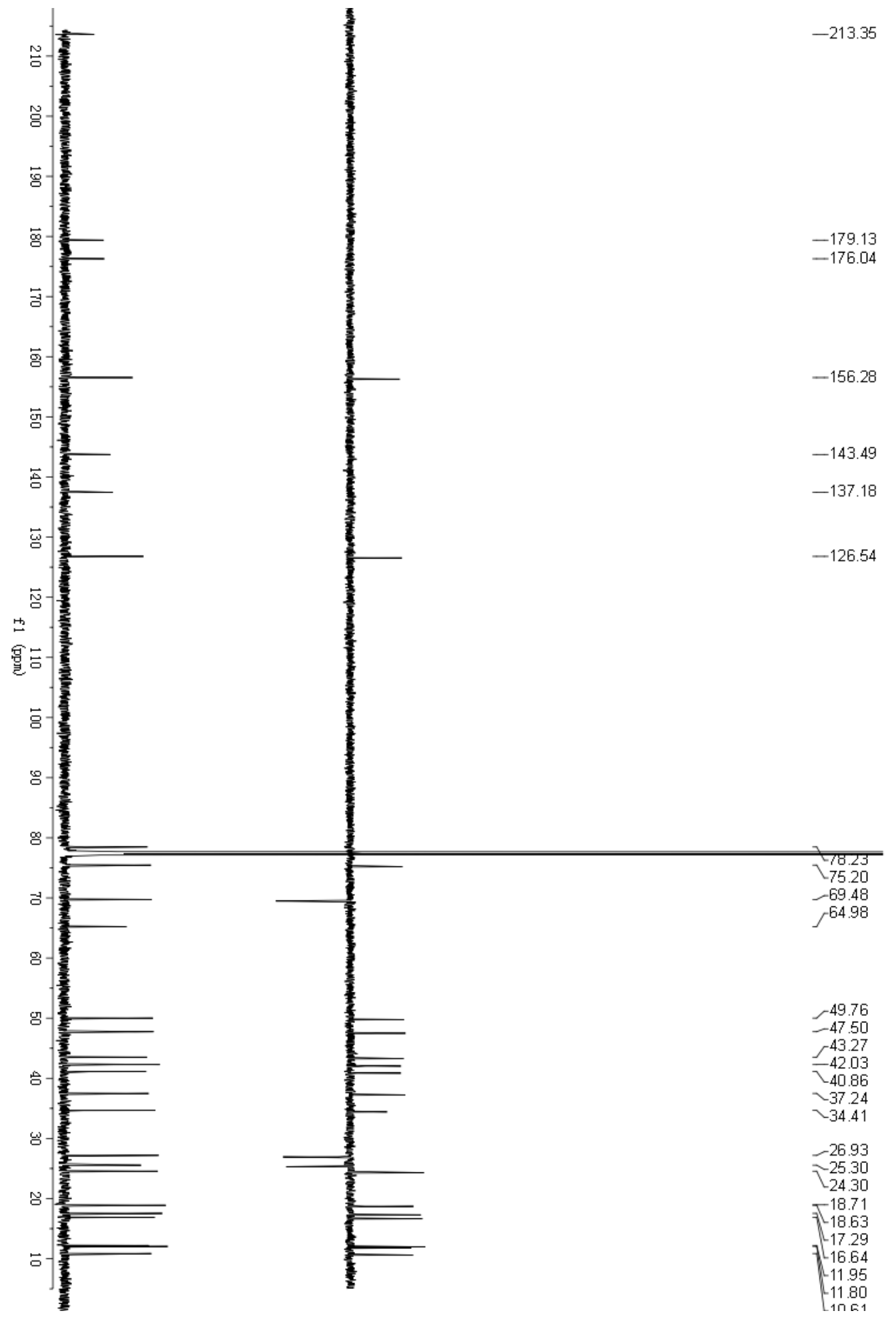


Figure S10. HSQC spectrum of compound $\mathbf{1}$ in $\mathrm{CDCl}_{3}$.

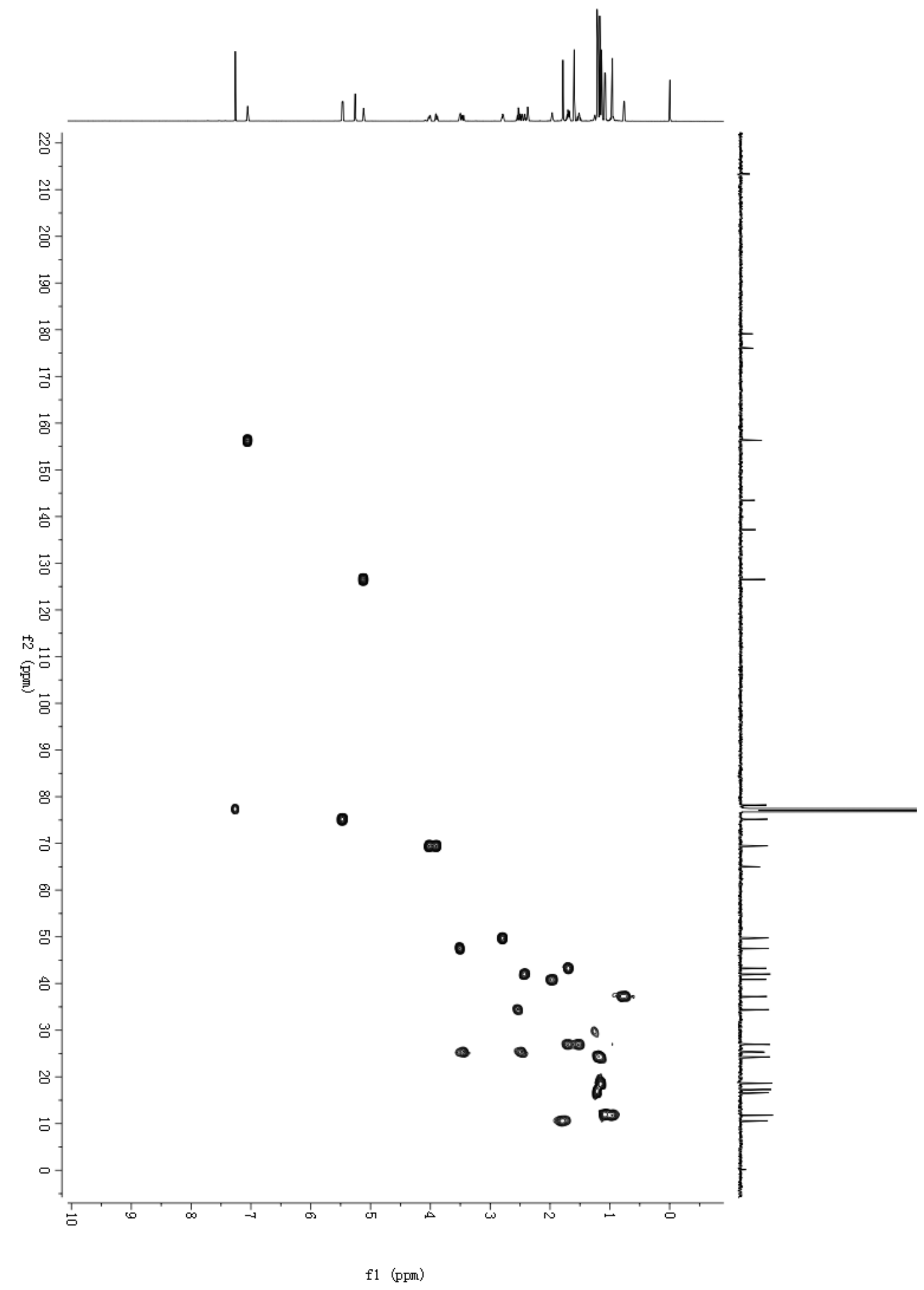


Figure S11. ${ }^{1} \mathrm{H}-{ }^{1} \mathrm{H}$ COSY spectrum of compound $\mathbf{1}$ in $\mathrm{CDCl}_{3}$.

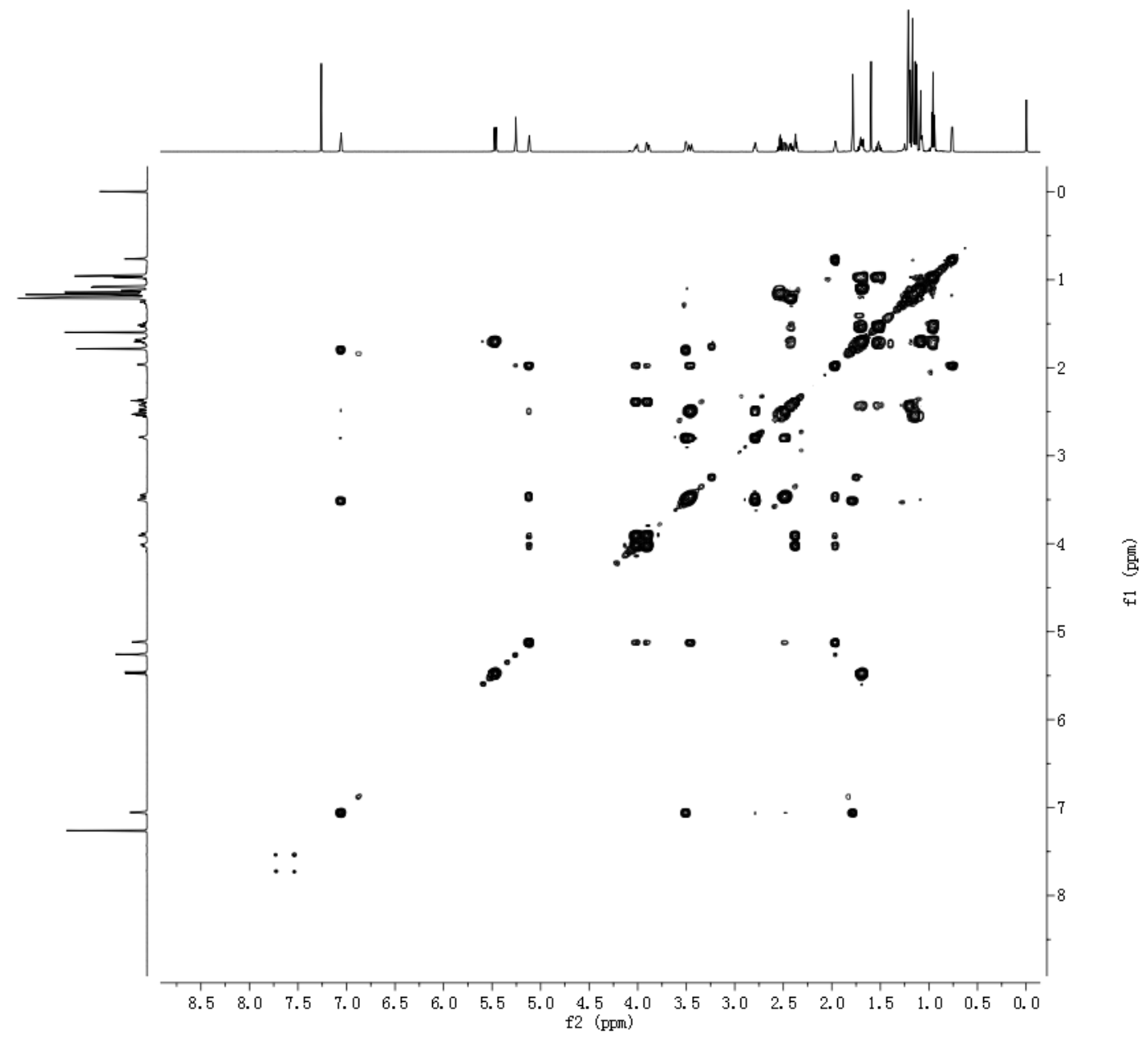


Figure S12. HMBC spectrum of compound 1 in $\mathrm{CDCl}_{3}$.

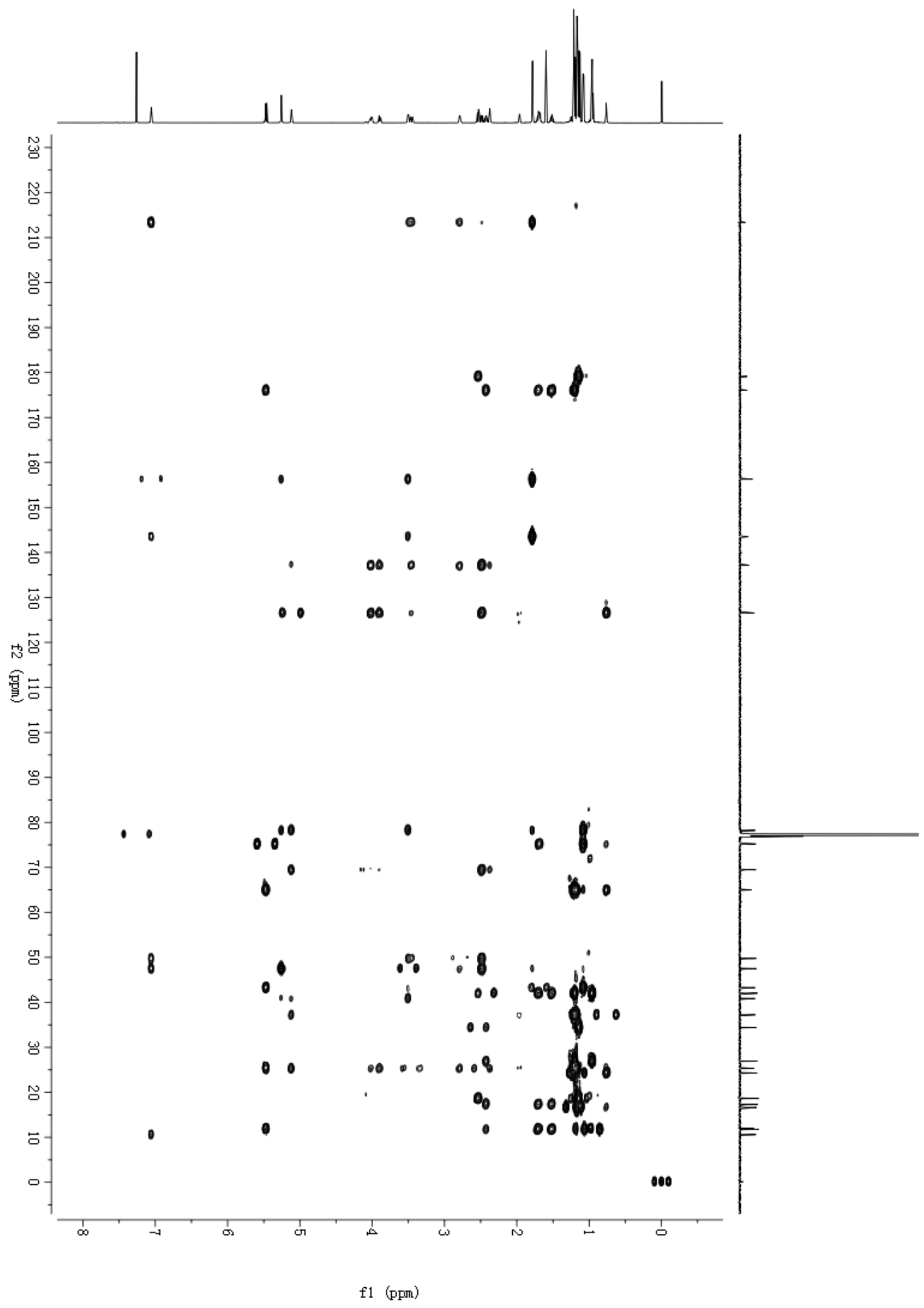


Figure S13. NOESY spectrum of compound 1 in $\mathrm{CDCl}_{3}$.

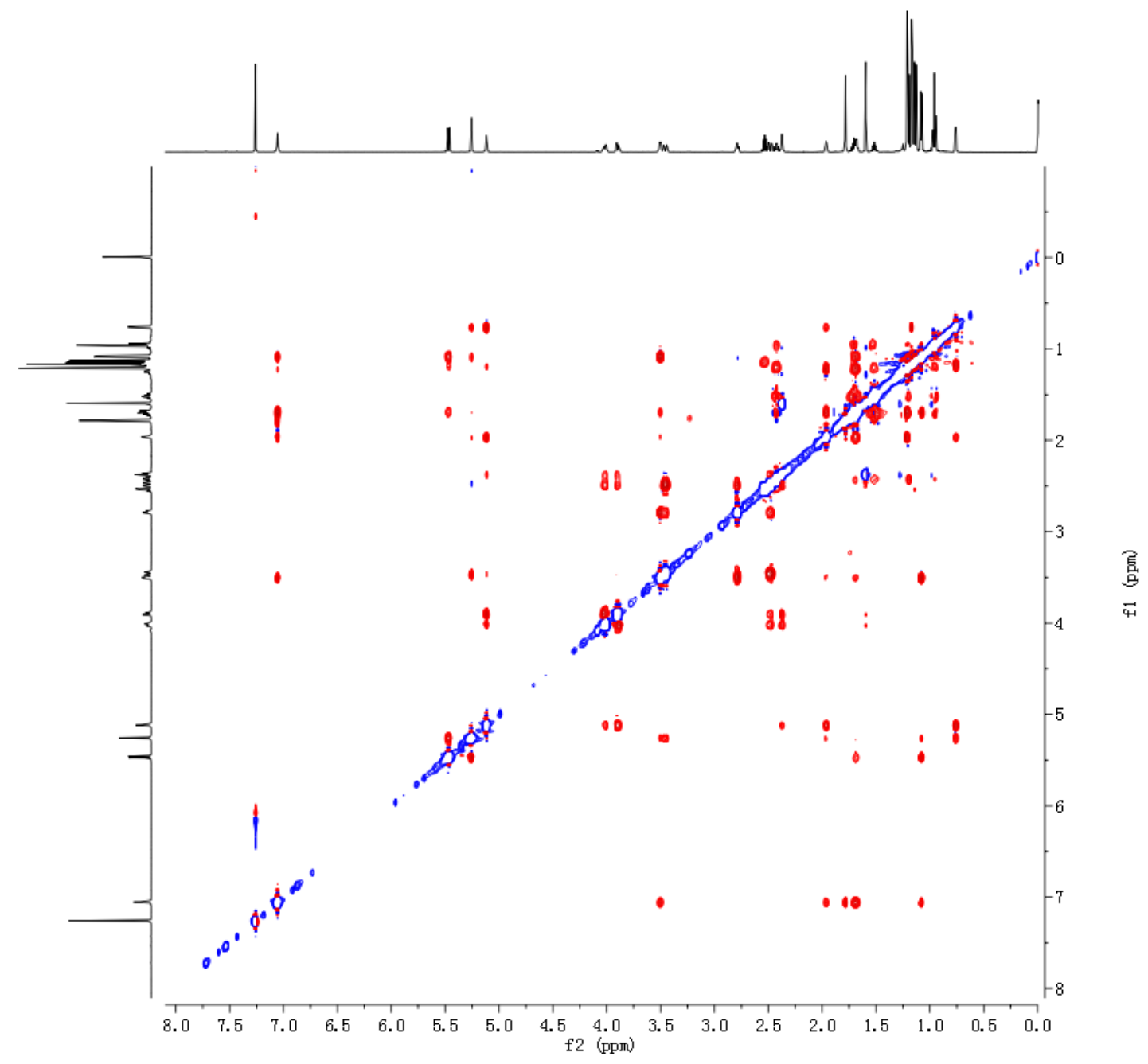


Figure S14. (+)-ESIMS spectrum of compound 1.

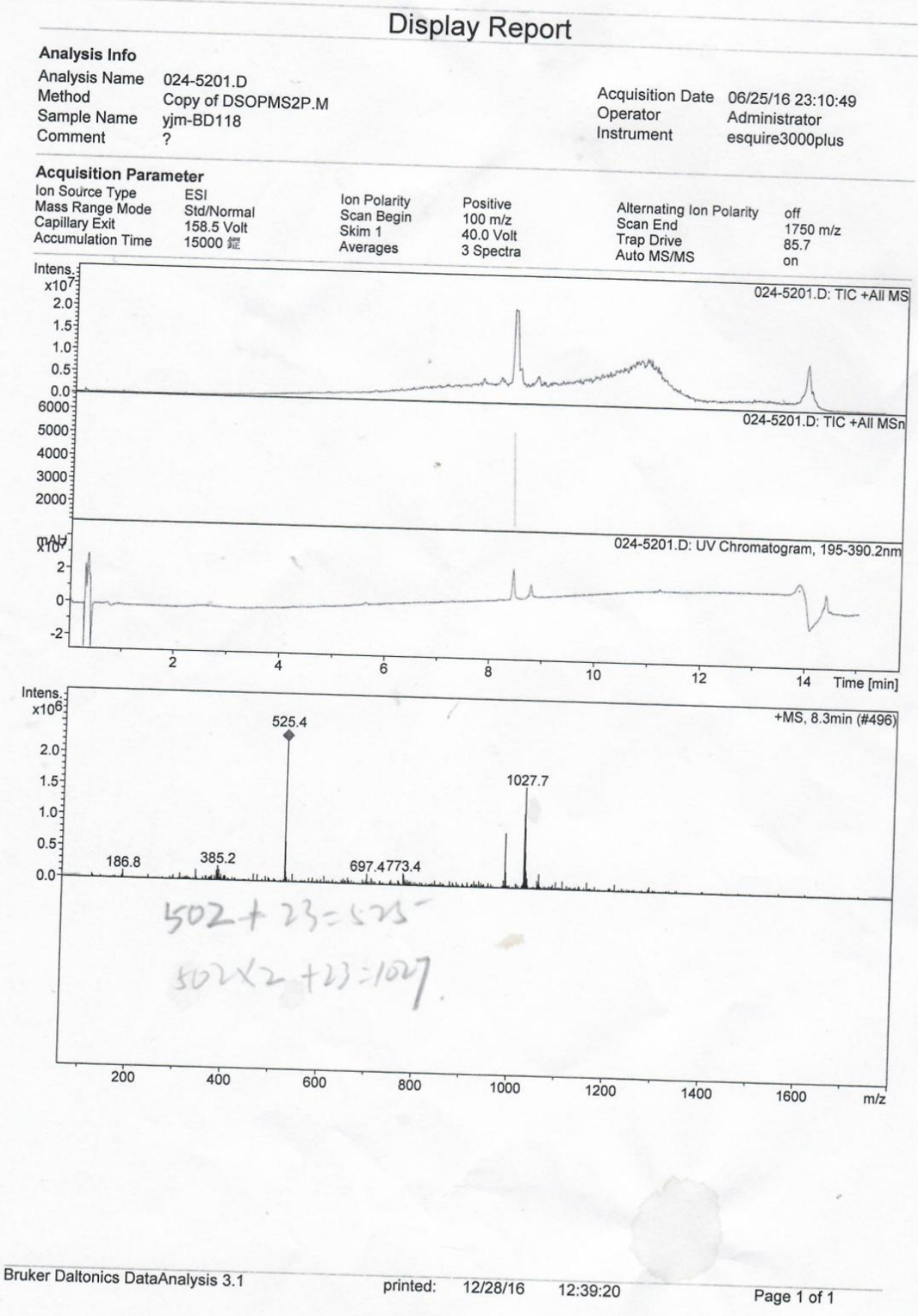


Figure S15. (+)-HRESIMS spectrum of compound 1.

Elemental Composition Report

Page 1

Single Mass Analysis

Tolerance $=3.0$ PPM / DBE: $\min =-1.5, \max =50.0$

Element prediction: Of

Number of isotope peaks used for $\mathrm{i}-\mathrm{FIT}=3$

Monoisotopic Mass, Even Electron lons

242 formula(e) evaluated with 1 results within limits (up to 50 best isotopic matches for each mass)

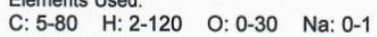

LCT PXE KE 324

30-Jun-2017

BD118 48 (1.023) $\mathrm{Cm}(41: 46: 08)$

1: TOF MS ES+

-

$1.85 \mathrm{e}+004$

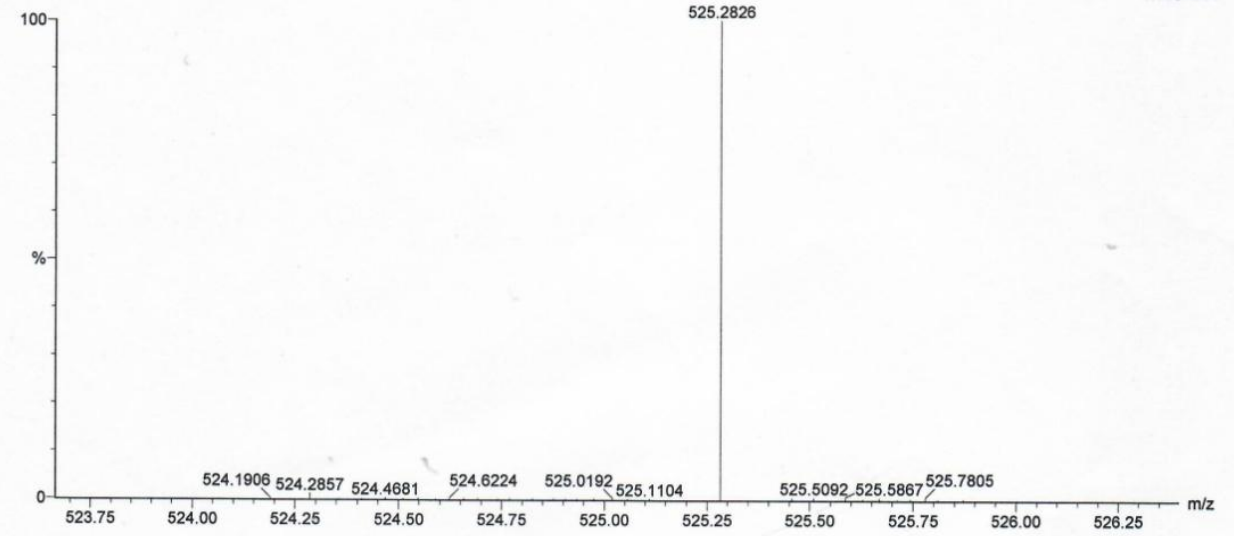

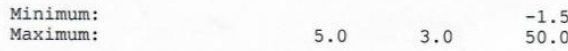

Mass Calc. Mass mDa PPM DBE i-FIT i-FIT (Norm) Formula

$\begin{array}{lllllllllll}525.2826 & 525.2828 & -0.2 & -0.4 & 8.5 & 96.5 & 0.0 & \text { C29 } & \text { H42 } & 07 & \text { Na }\end{array}$ 
Figure S16. IR spectrum of compound 1.

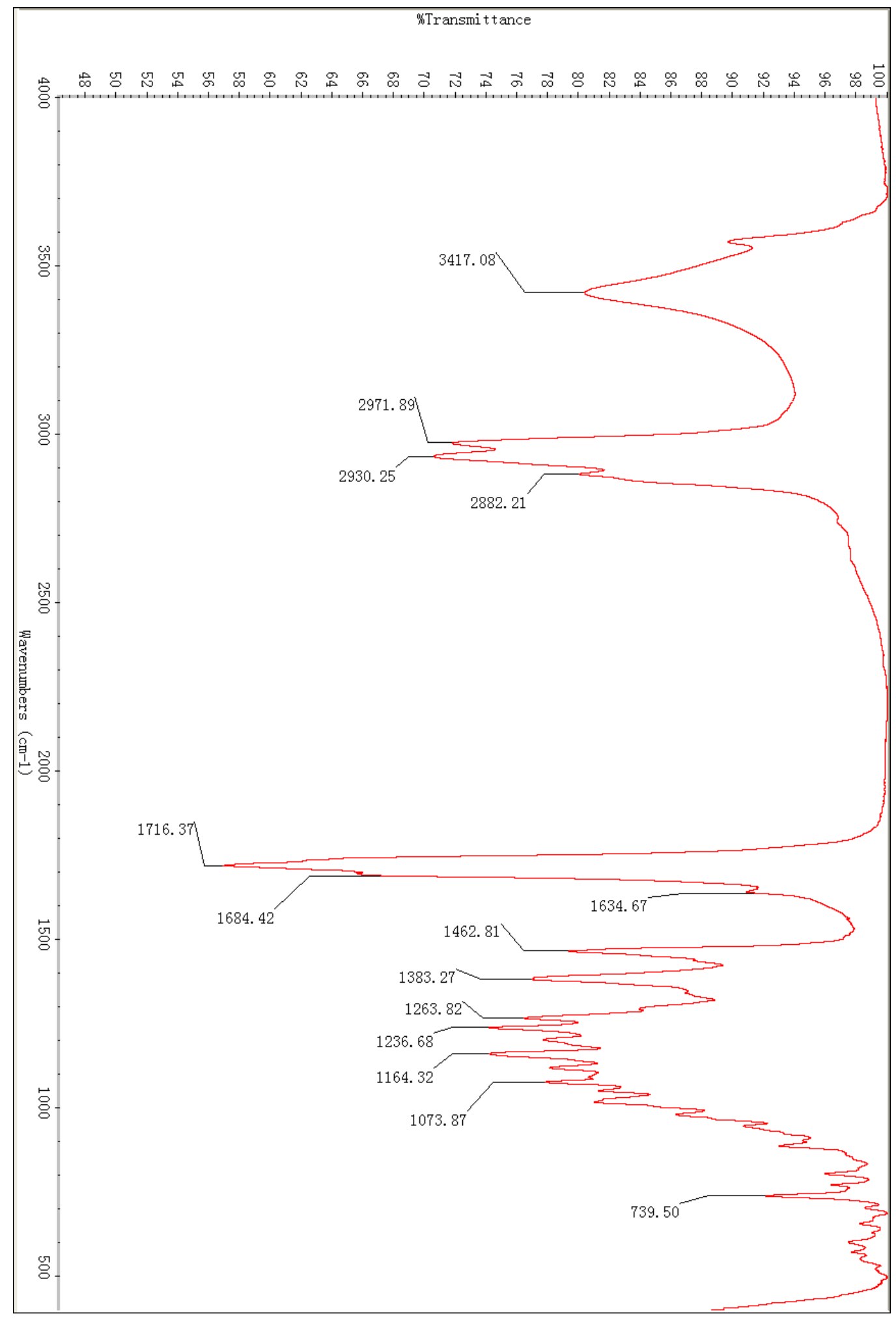


Figure S17. ${ }^{1} \mathrm{H}$ NMR spectrum of compound $\mathbf{2}$ in $\mathrm{CDCl}_{3}$.
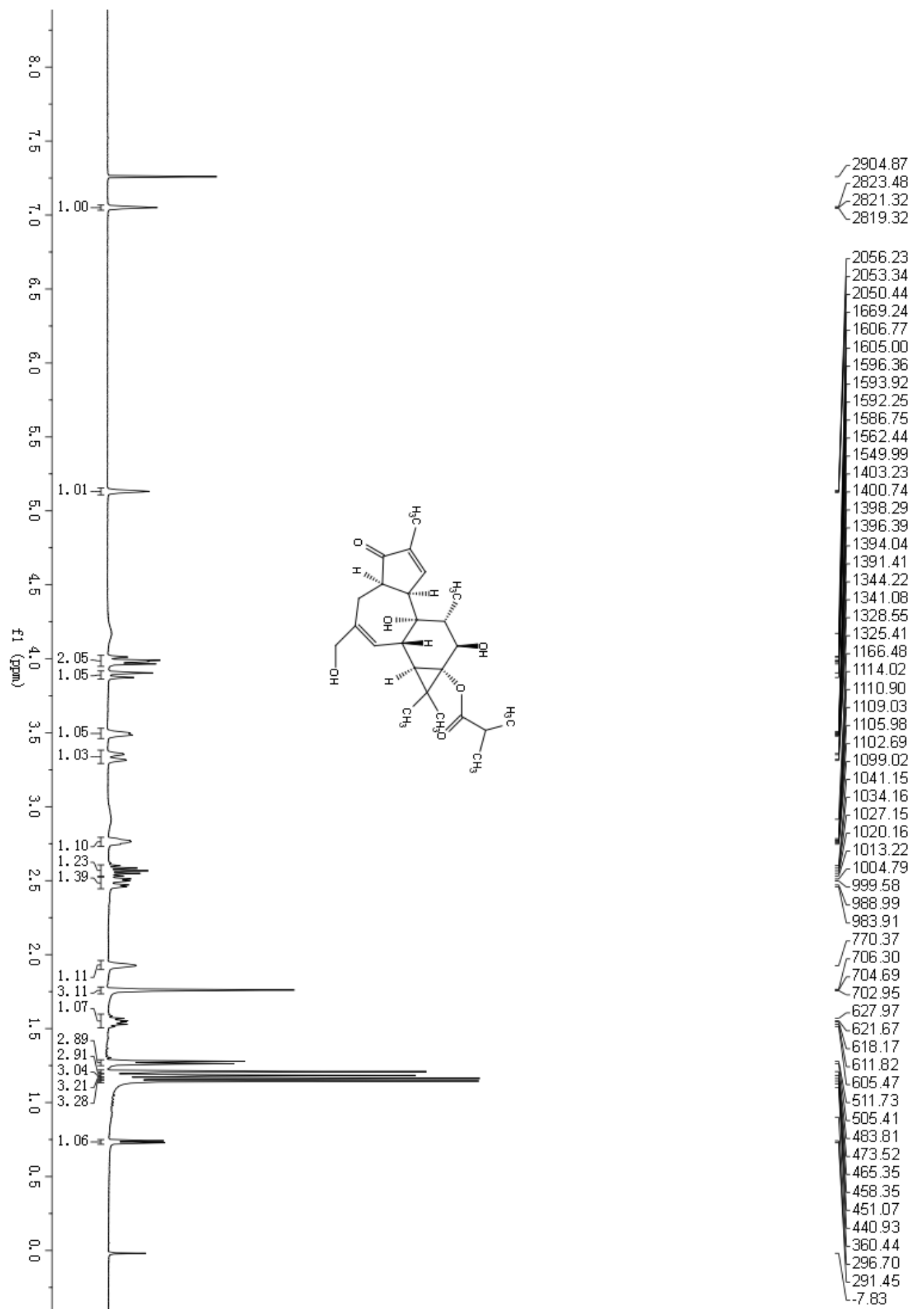
Figure S18. ${ }^{13} \mathrm{C}$ NMR spectrum of compound 2 in $\mathrm{CDCl}_{3}$.

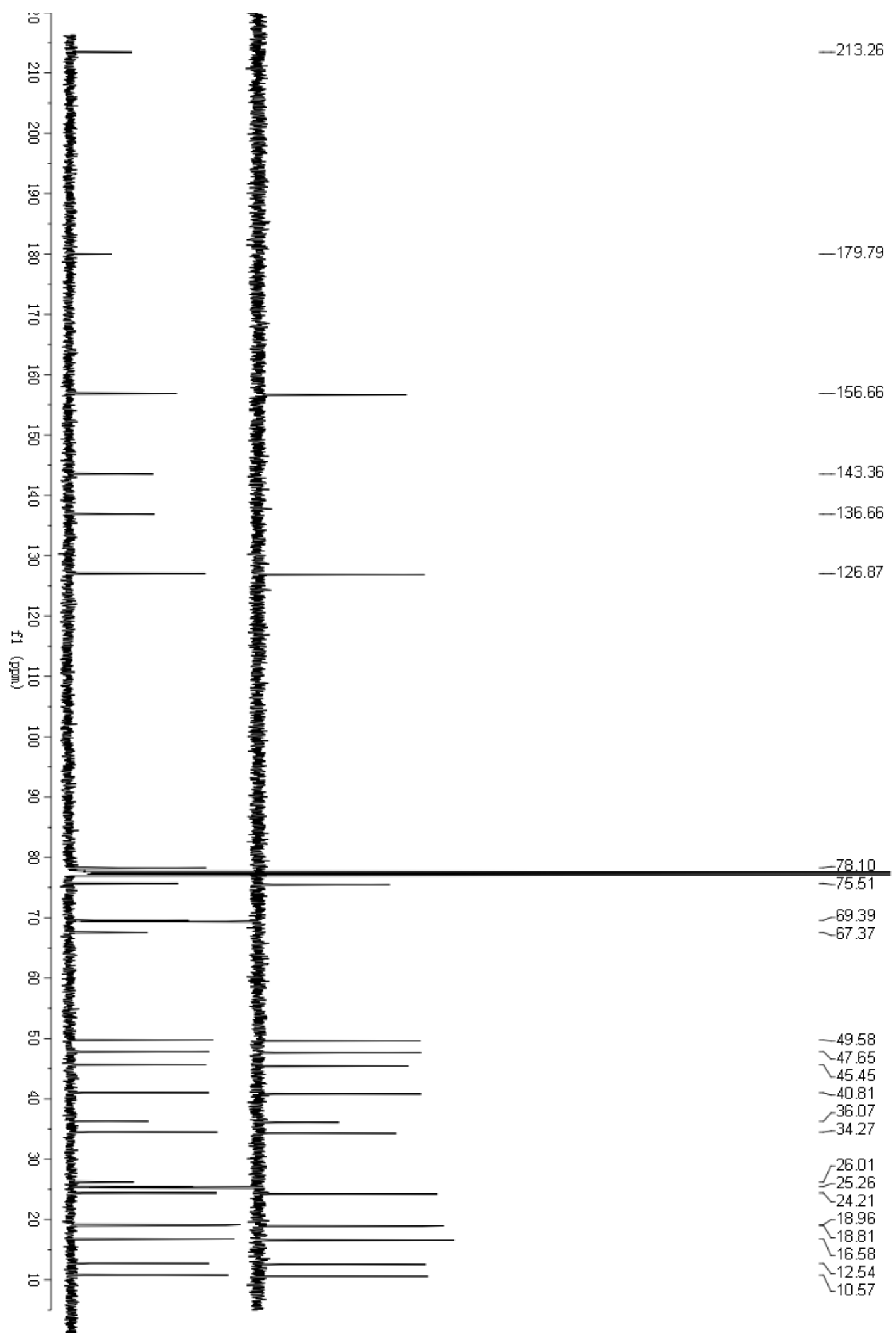


Figure S19. HSQC spectrum of compound 2 in $\mathrm{CDCl}_{3}$.

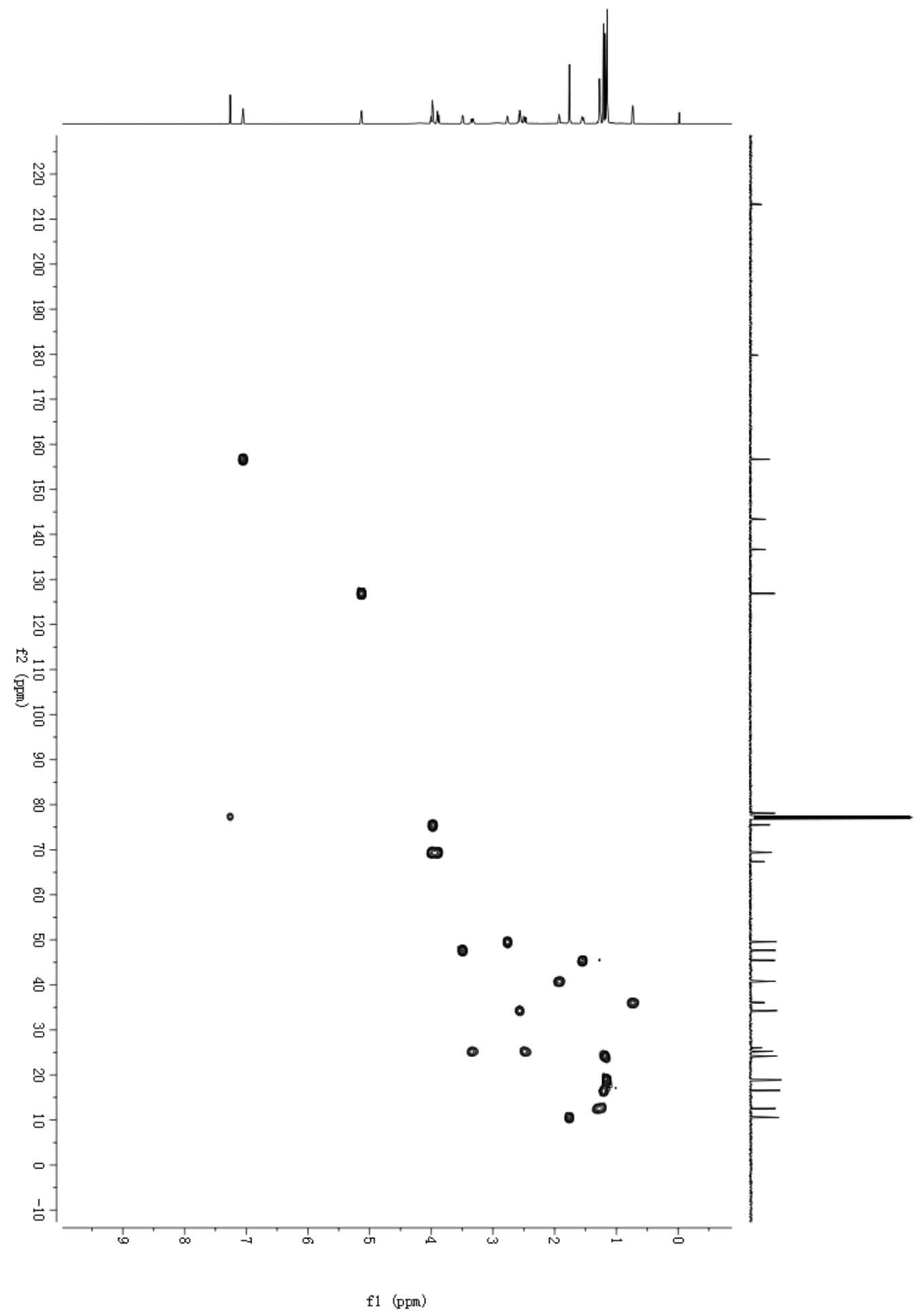


Figure S20. ${ }^{1} \mathrm{H}-{ }^{1} \mathrm{H}$ COSY spectrum of compound 2 in $\mathrm{CDCl}_{3}$.

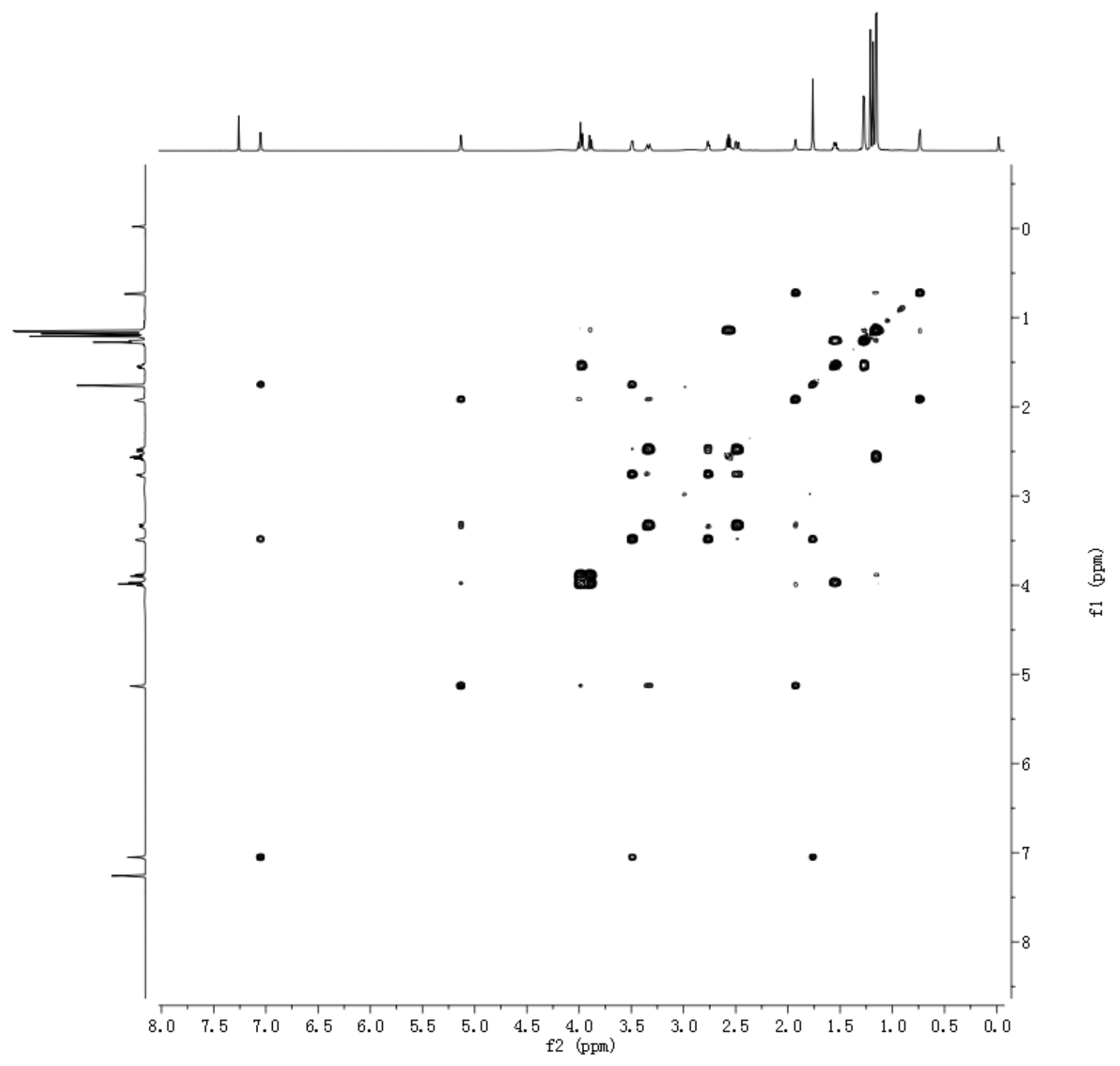


Figure S21. $\mathrm{HMBC}$ spectrum of compound 2 in $\mathrm{CDCl}_{3}$.

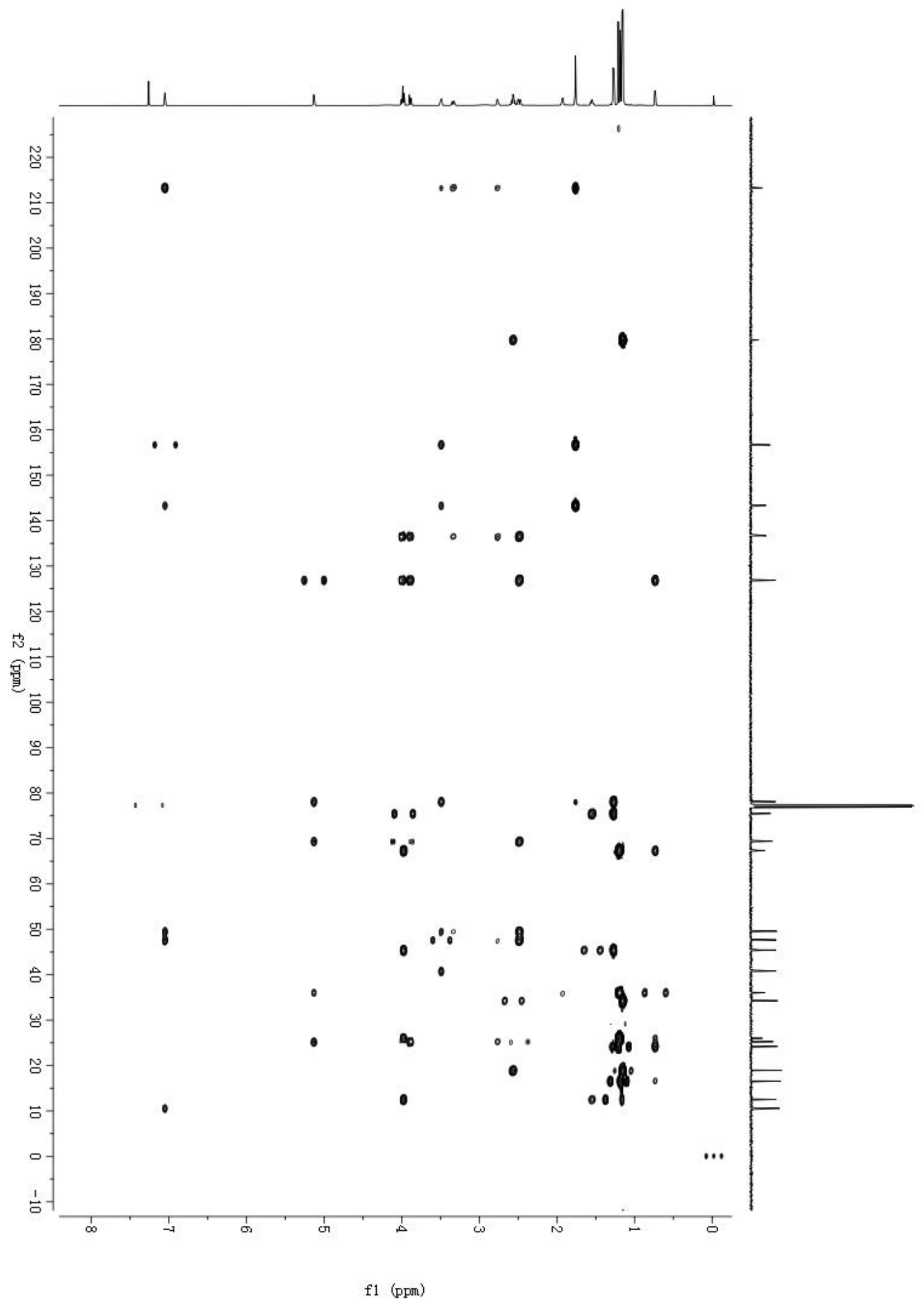


Figure S22. NOESY spectrum of compound 2 in $\mathrm{CDCl}_{3}$.

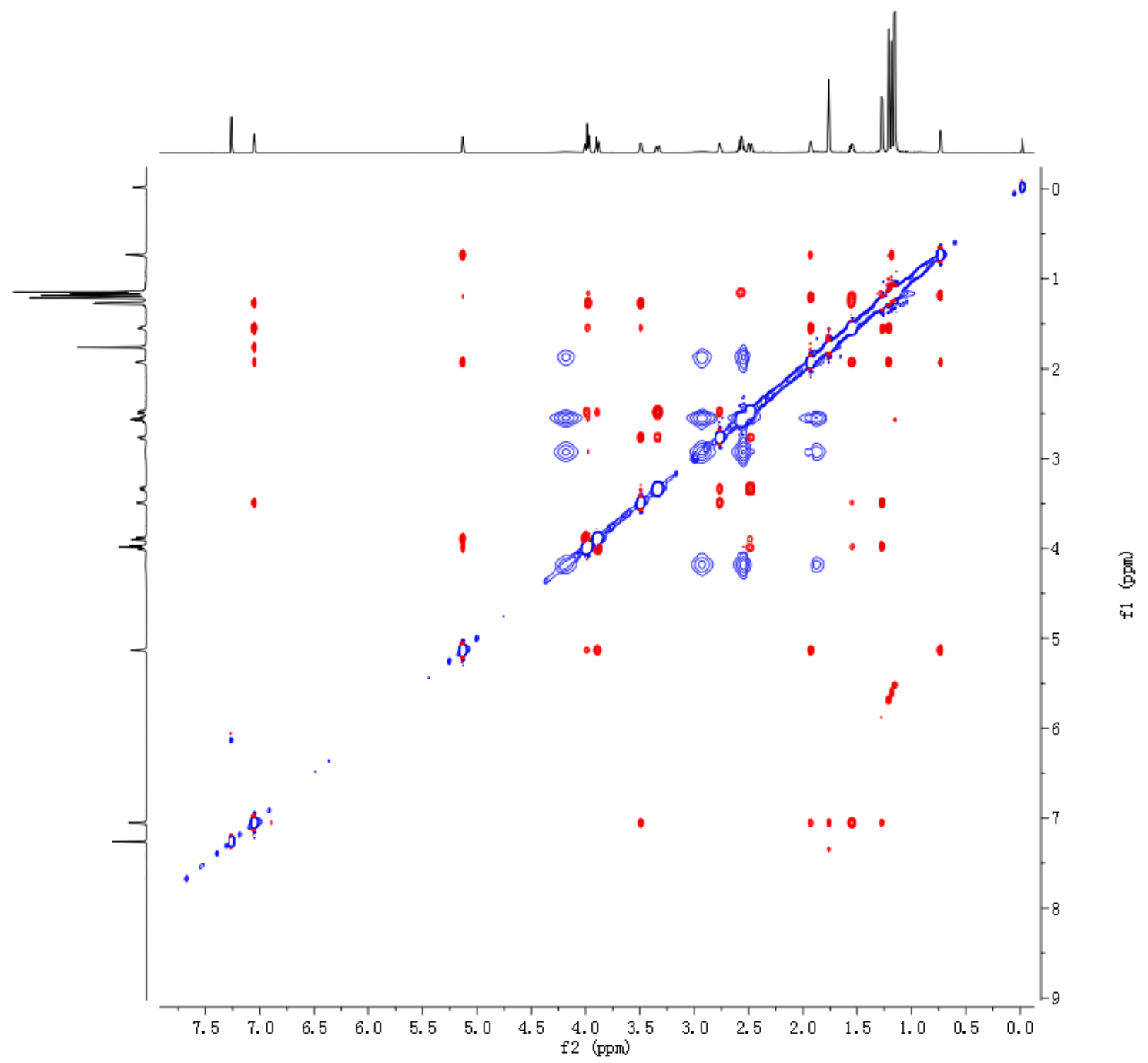


Figure S23. (+)-ESIMS spectrum of compound 2.

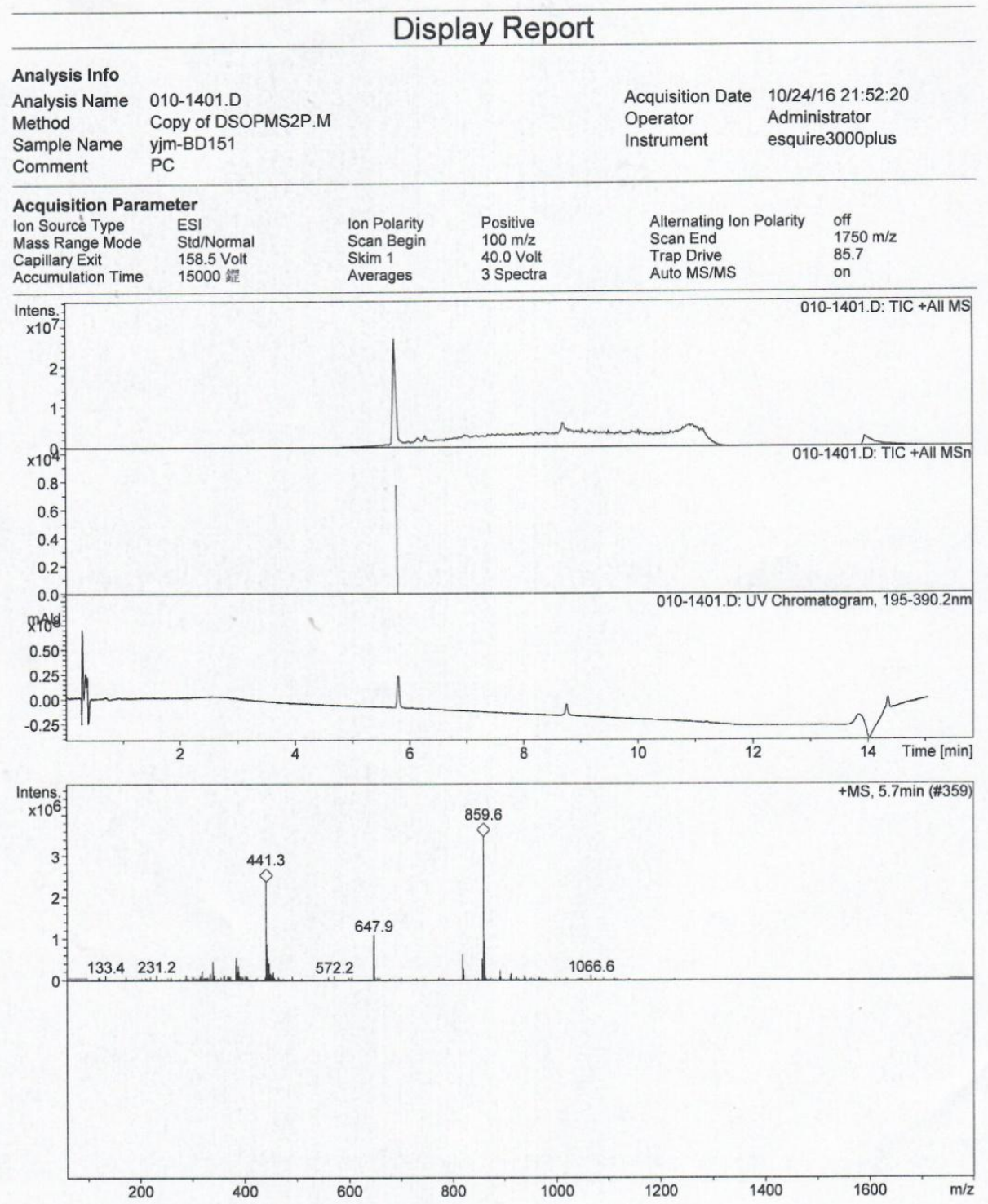

Bruker Daltonics DataAnalysis 3.1

printed: $\quad 08 / 08 / 18 \quad 18: 51: 25$

Page 1 of 1 
Figure S24. (+)-HRESIMS spectrum of compound 2.

Elemental Composition Report

Page 1

Single Mass Analysis

Tolerance $=0.4$ PPM / DBE: $\min =-1.5, \max =50.0$

Element prediction: Off

Number of isotope peaks used for $\mathrm{i}-\mathrm{FIT}=$

Monoisotopic Mass, Even Electron Ions

178 formula(e) evaluated with 1 results within limits (up to 50 best isotopic matches for each mass)

Elements Used:

$\begin{array}{llll}\text { C: } 5-80 & \text { H: } 2-120 & \text { O: } 0-30 & \mathrm{Na}: 0-1\end{array}$

LCT PXE KE324

30-Jun-2017

BD151 $52(1.146) \mathrm{Cm}(46: 53)$

1: TOF MS ES+

\section{4}

$1.07 \mathrm{e}+004$

100<smiles>C1CCC2CCCC2C1</smiles>

$+$

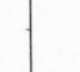

$\%-$
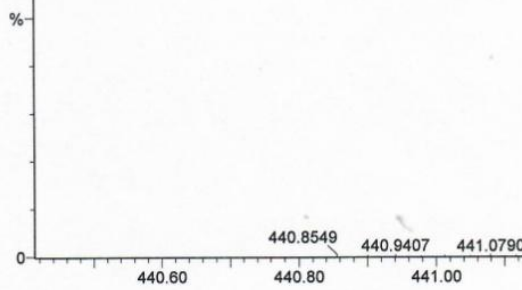

$41.4086 \quad 441.5214 \quad 441.6134$

inimum: $5.0-1.5$

Mass Calc. Mass mDa PPM DBE i-FIT i-FIT (Norm) Formula

$\begin{array}{lllllllllll}441.2254 & 441.2253 & 0.1 & 0.2 & 7.5 & 77.1 & 0.0 & \text { C24 } & \text { H34 } & \text { O6 } & \text { Na }\end{array}$ 
Figure S25. IR spectrum of compound 2.

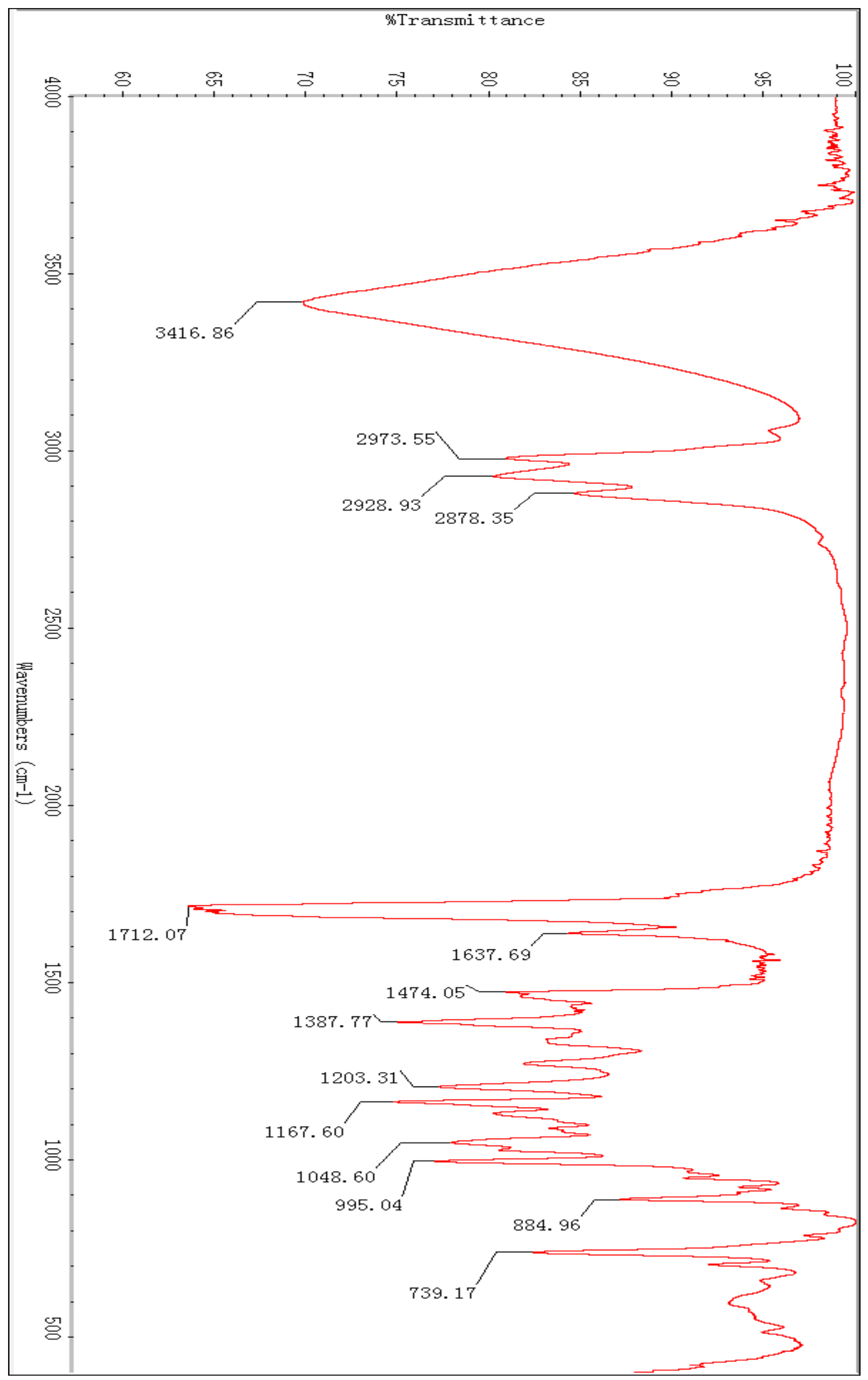


Figure S26. ${ }^{1} \mathrm{H}$ NMR spectrum of compound $\mathbf{3}$ in $\mathrm{CDCl}_{3}$.

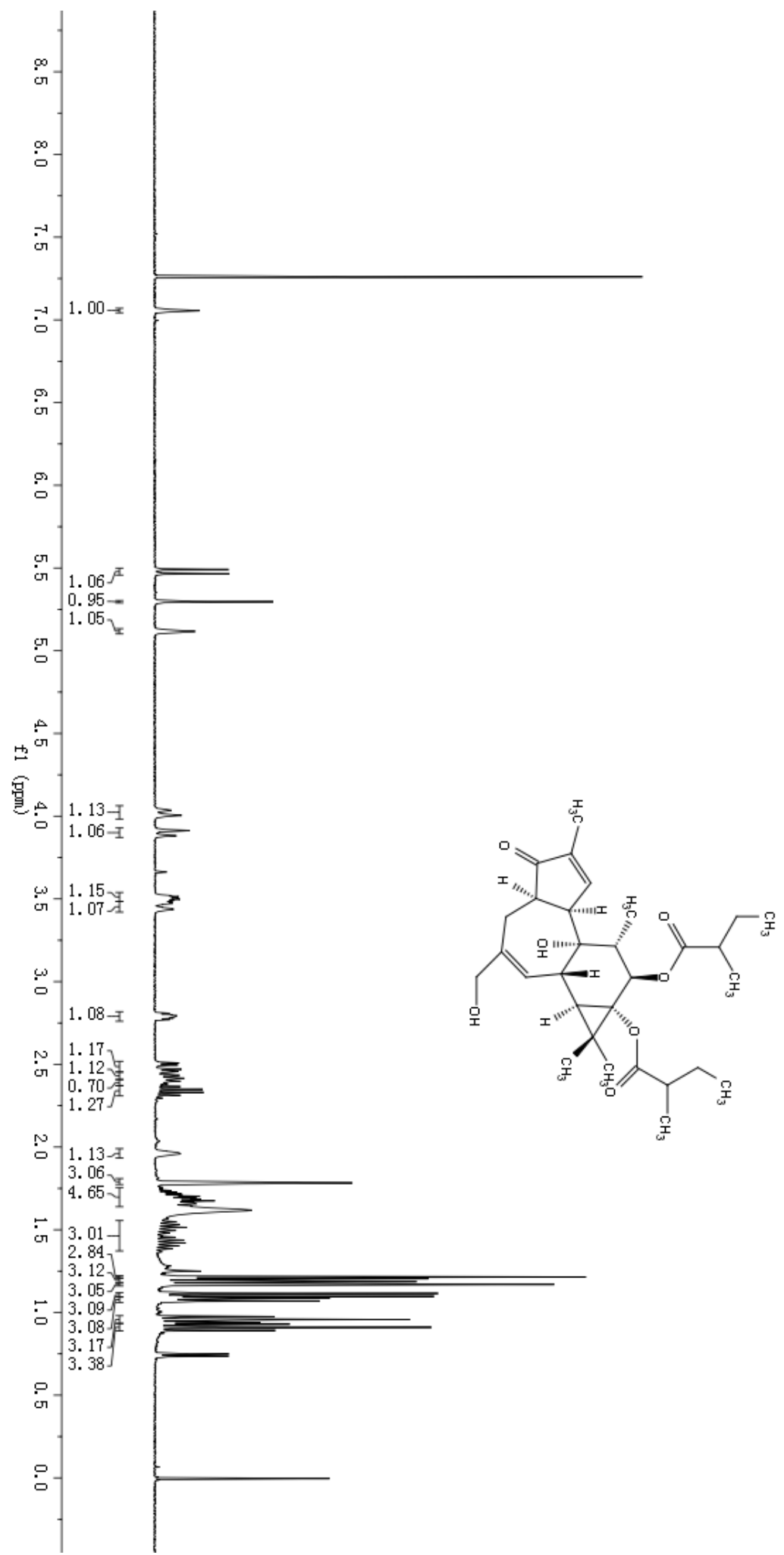


Figure S27. ${ }^{13} \mathrm{C}$ NMR spectrum of compound 3 in $\mathrm{CDCl}_{3}$.

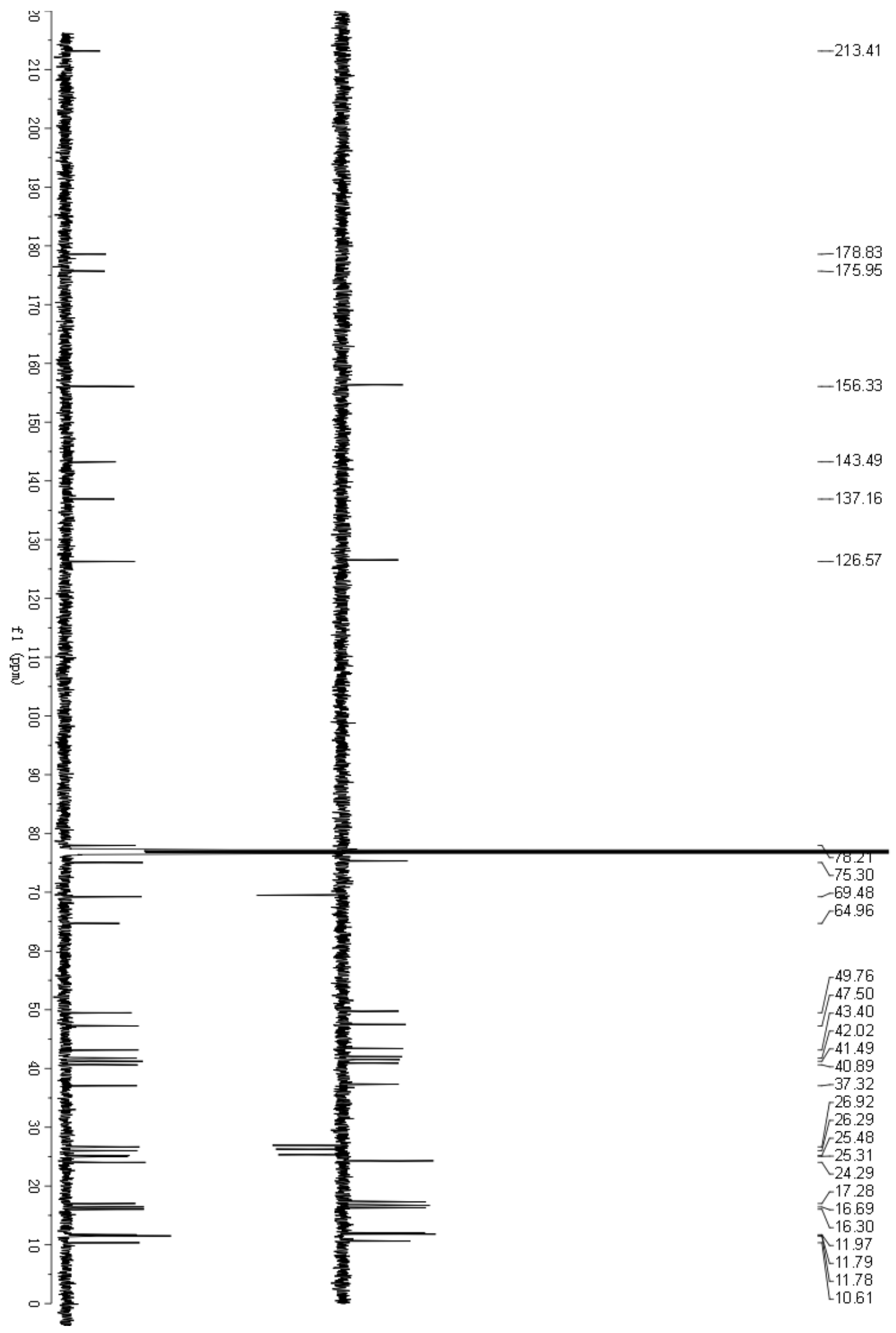


Figure S28. HSQC spectrum of compound $\mathbf{3}$ in $\mathrm{CDCl}_{3}$.

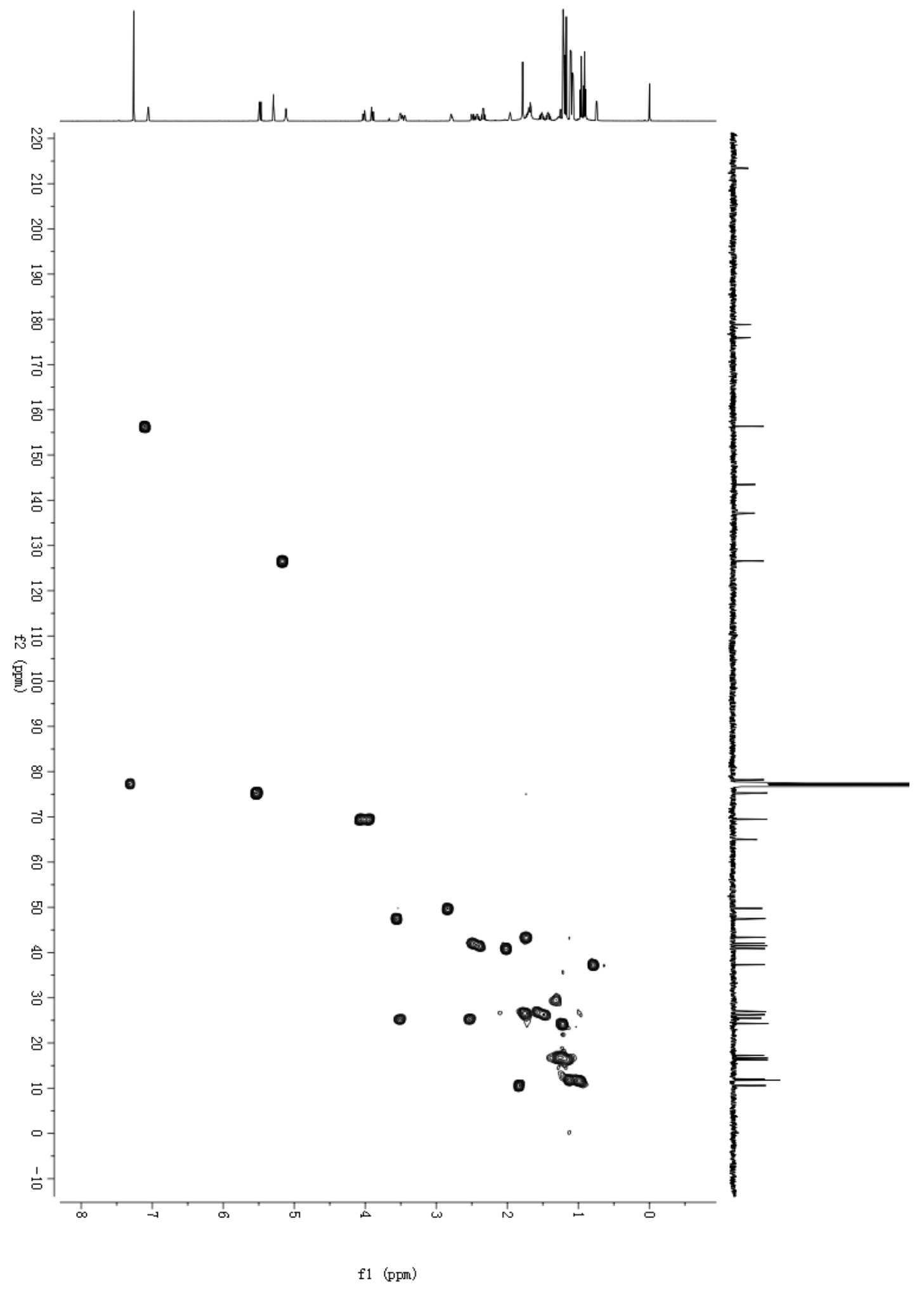


Figure S29. ${ }^{1} \mathrm{H}-{ }^{1} \mathrm{H}$ COSY spectrum of compound 3 in $\mathrm{CDCl}_{3}$.

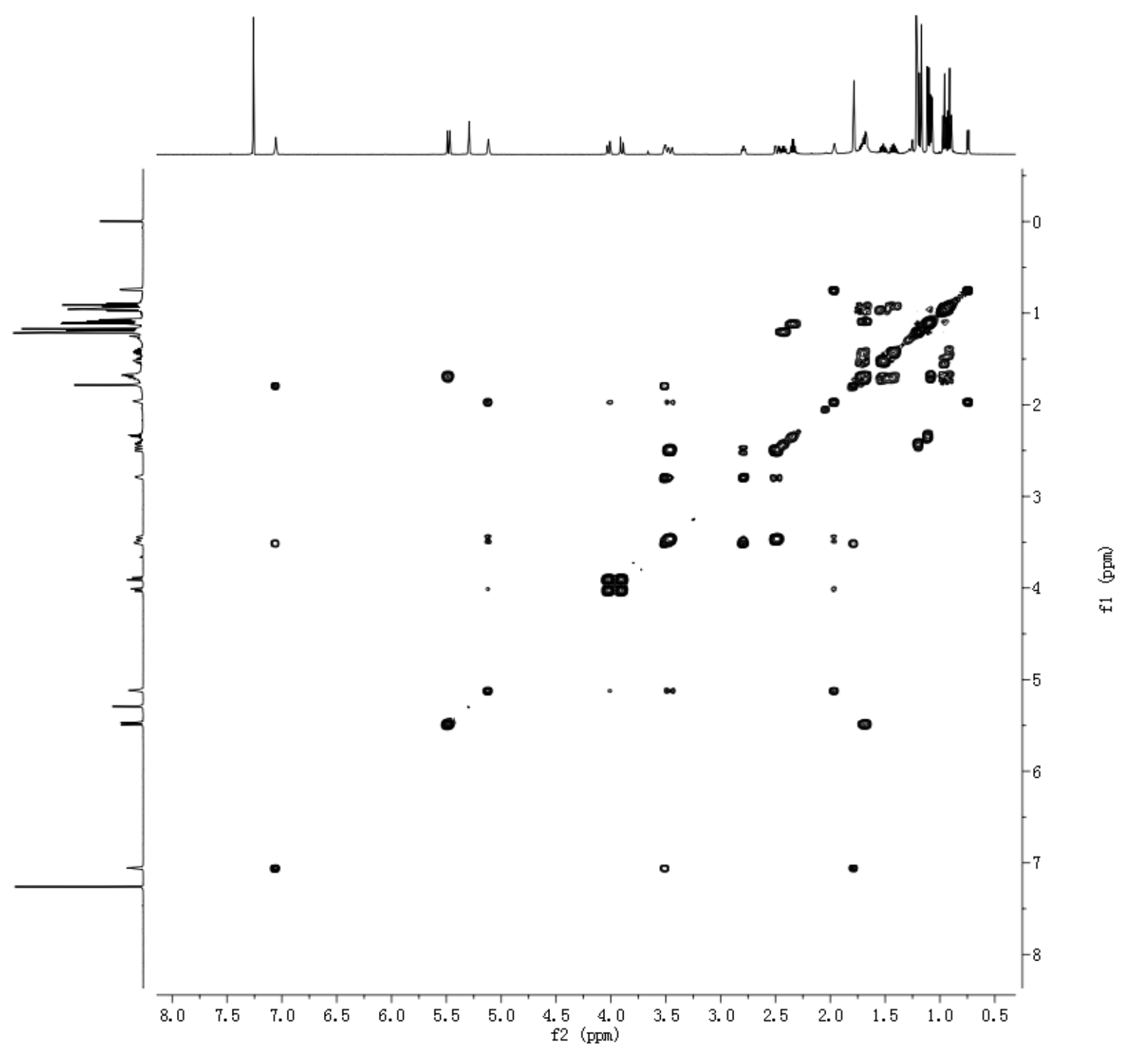


Figure S30. $\mathrm{HMBC}$ spectrum of compound $\mathbf{3}$ in $\mathrm{CDCl}_{3}$.

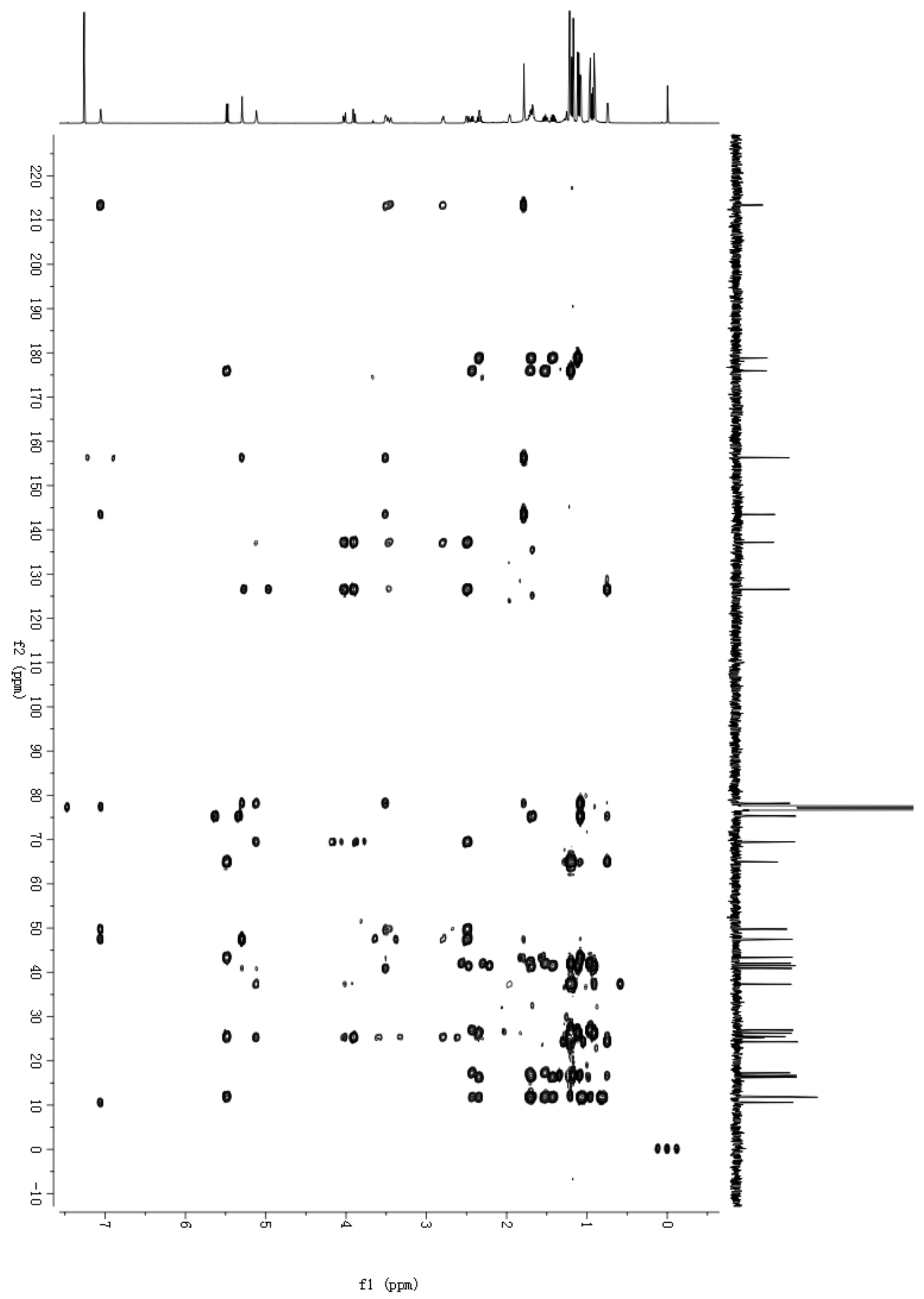


Figure S31. NOESY spectrum of compound 3 in $\mathrm{CDCl}_{3}$.

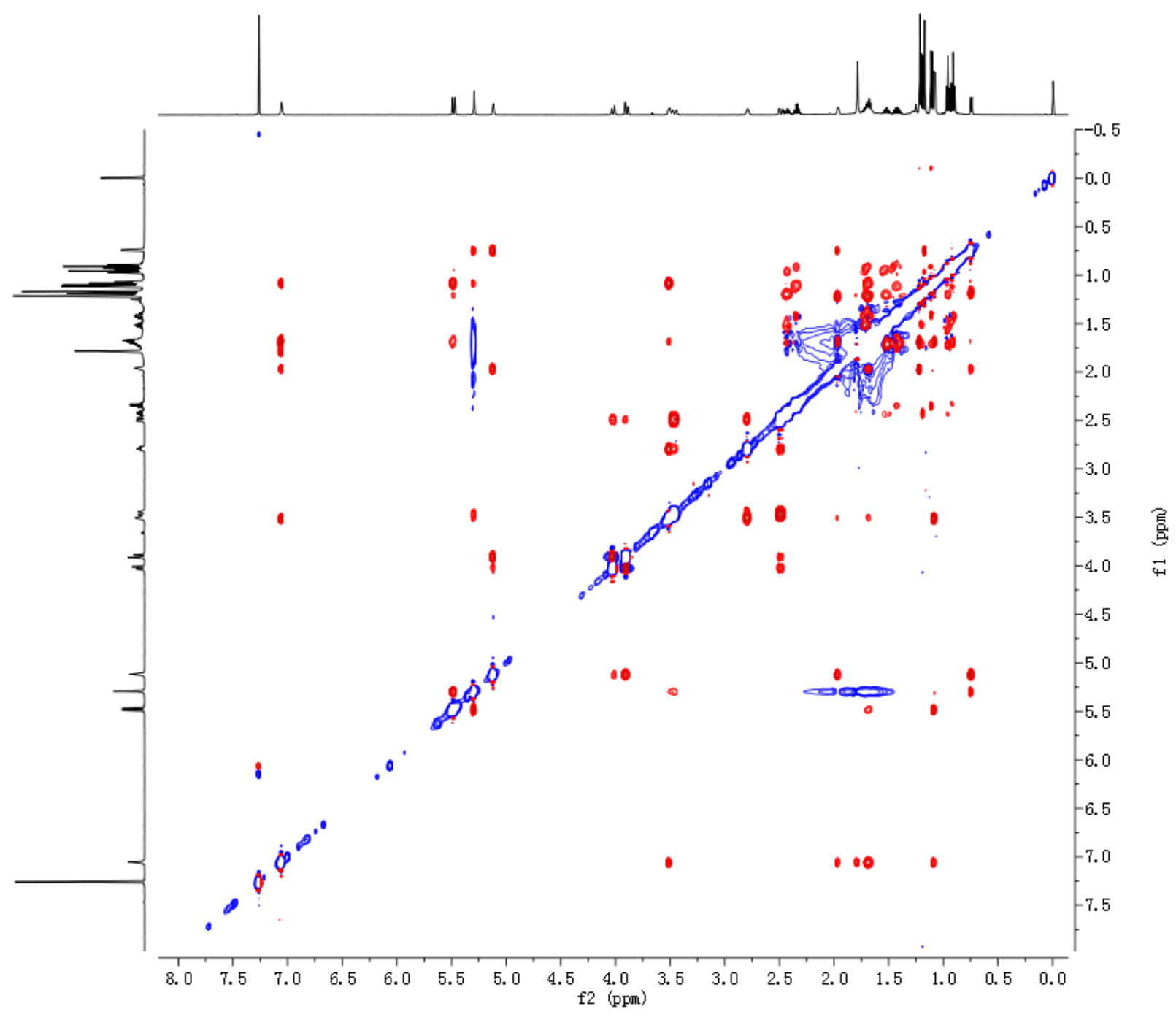


Figure S32. (+)-ESIMS spectrum of compound 3.

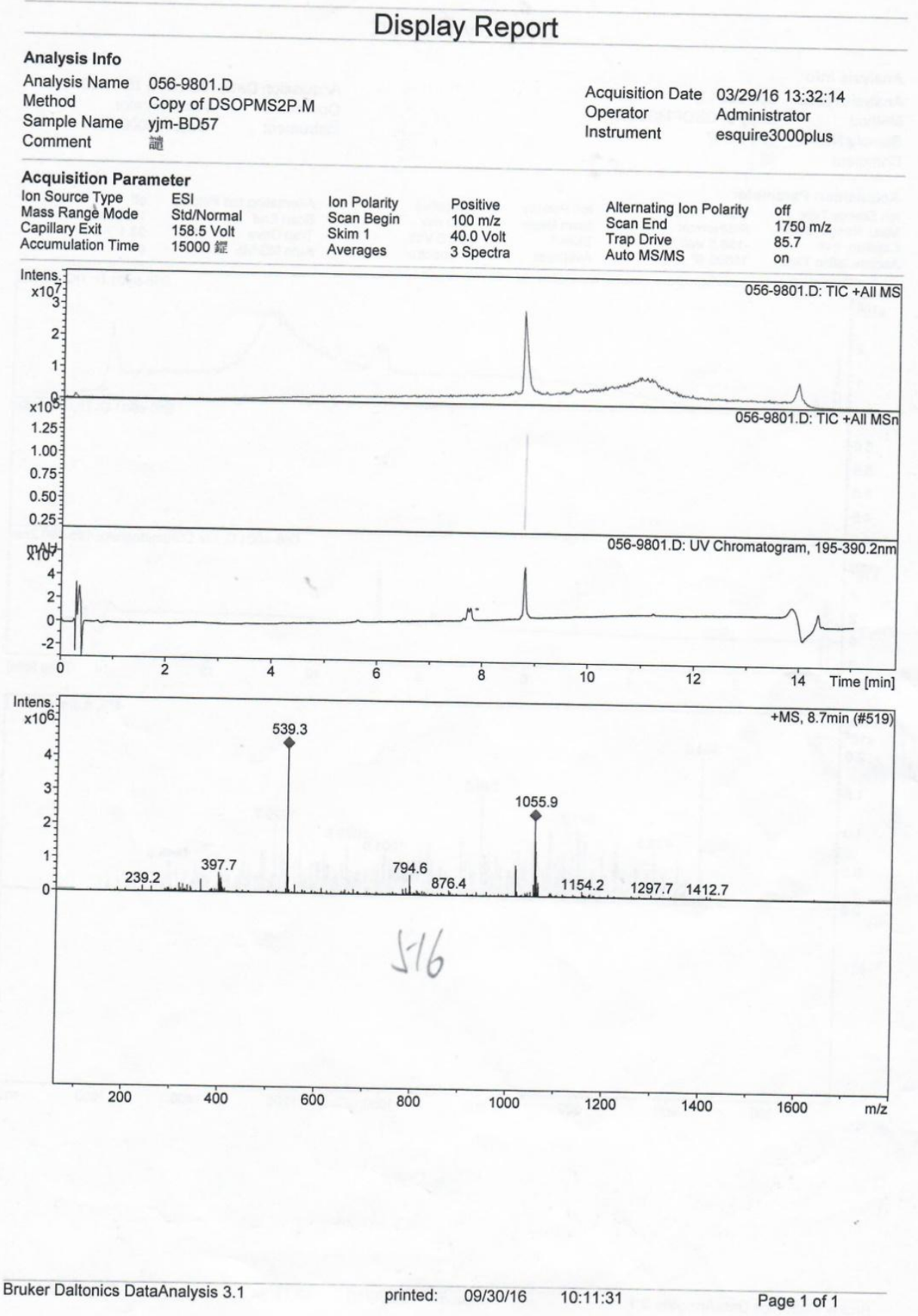


Figure S33. (+)-HRESIMS spectrum of compound 3.

Elemental Composition Report

Single Mass Analysis

Tolerance $=3.0$ PPM / DBE: $\min =-1.5, \max =50.0$

Element prediction: Off

Number of isotope peaks used for $\mathrm{i}-\mathrm{FIT}=3$

Monoisotopic Mass, Even Electron Ions

253 formula(e) evaluated with 1 results within limits (up to 50 best isotopic matches for each mass)

Elements Used:

$\mathrm{H}: 2-120$ O: 0-30 Na: 0-

LCT PXE KE 324

30-Jun-2017

$15: 37: 45$
$3 D 5721(0.423) \mathrm{Cm}(20: 21)$

1: TOF MS ES+

$3.03 \mathrm{e}+003$

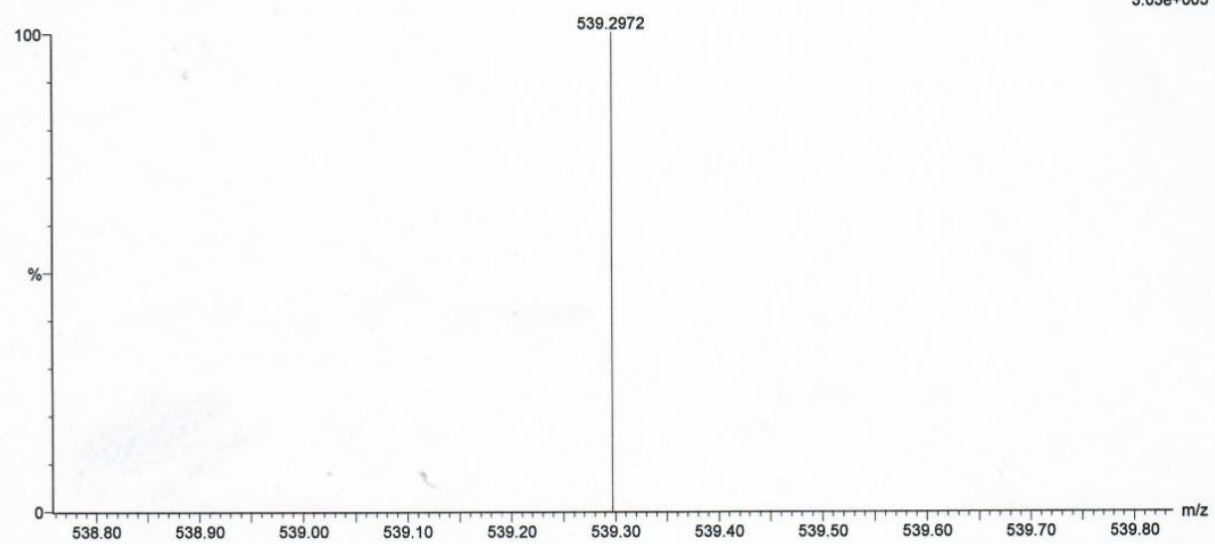

Minimum: -1.5

$\begin{array}{llll} & 5.0 & 3.0 & 50.0\end{array}$

Mass Calc. Mass mDa PPM DBE i-FIT i-FIT (Norm) Formula

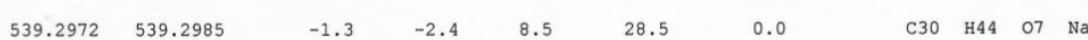


Figure S34. IR spectrum of compound 3 .

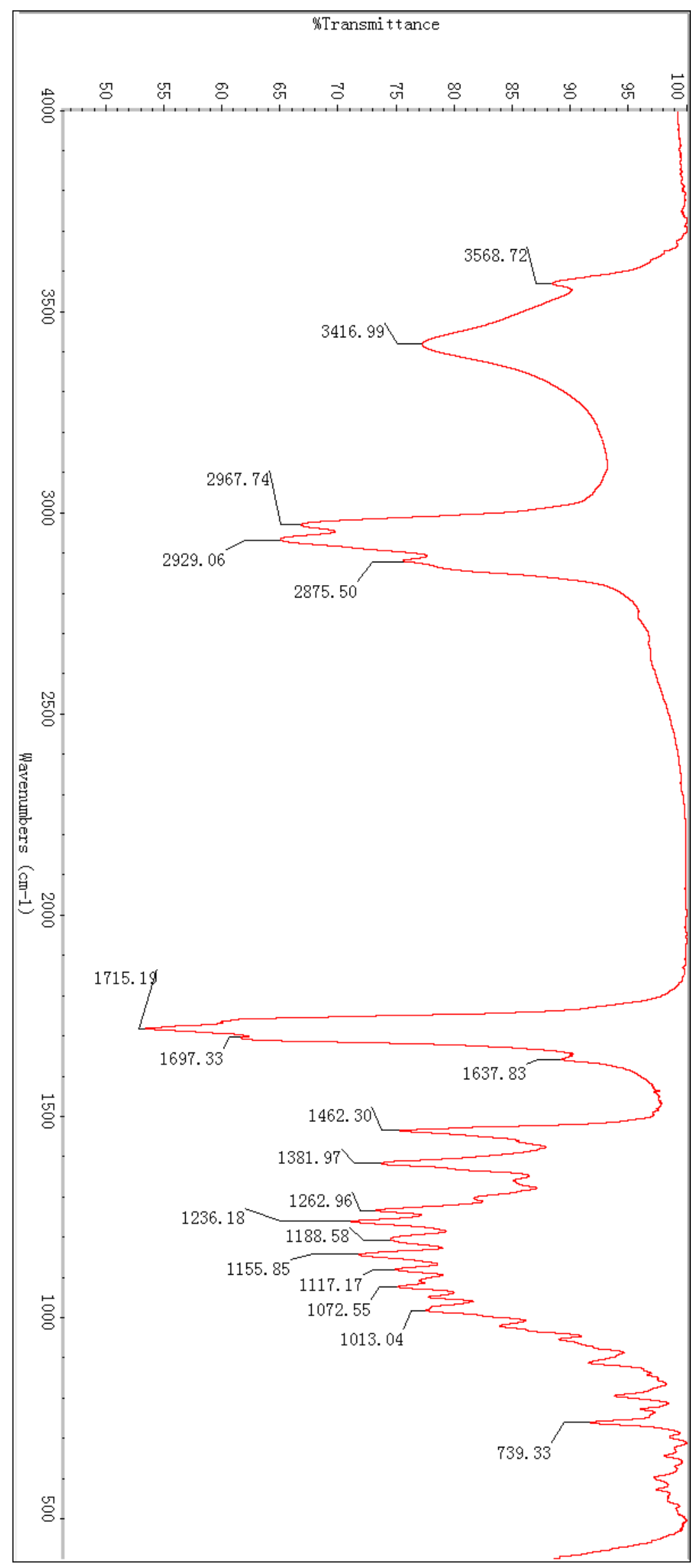


Figure S35. ${ }^{1} \mathrm{H}$ NMR spectrum of compound 4 in $\mathrm{CDCl}_{3}$.

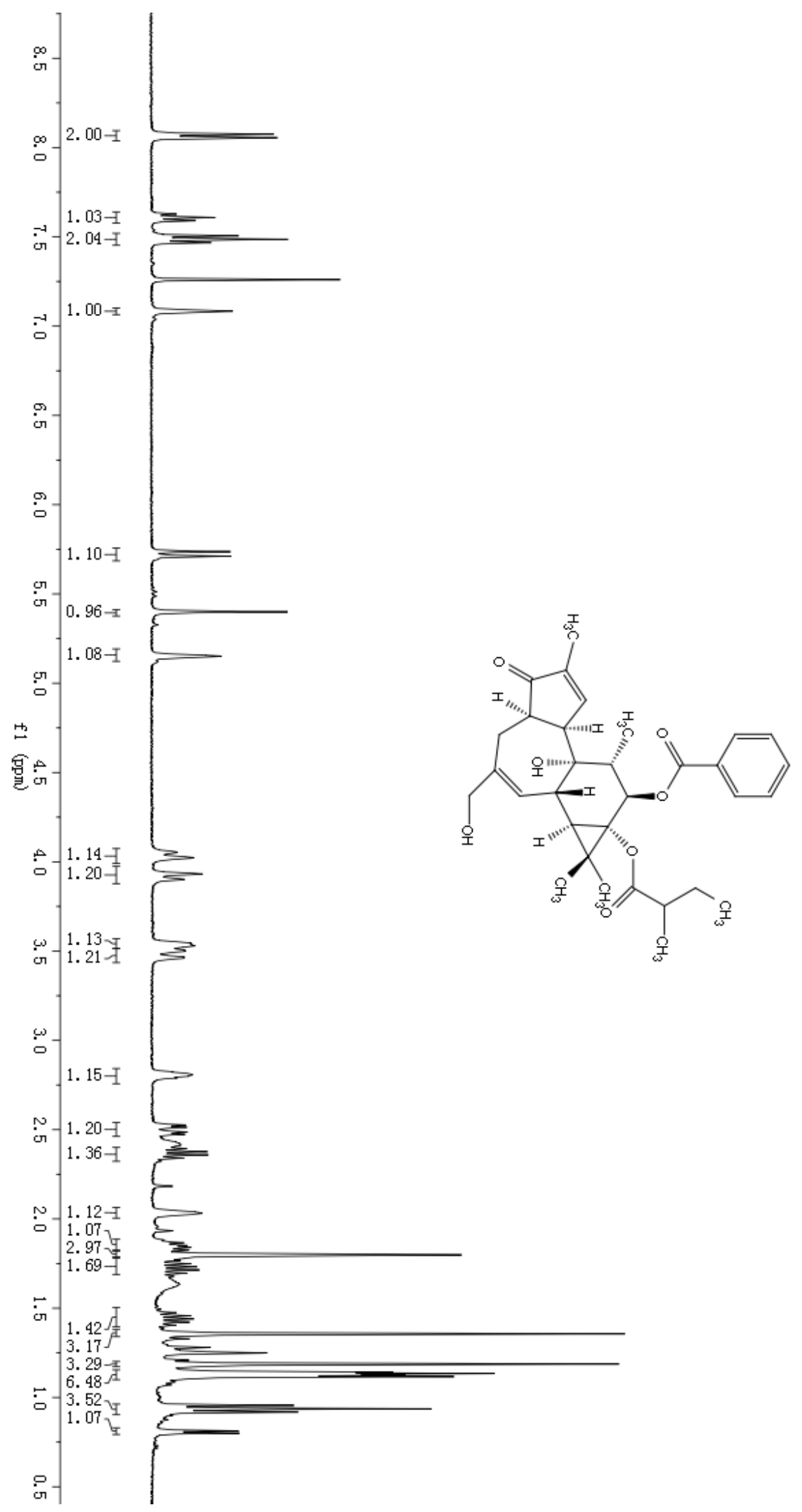

654.12

583.22

57621

$-569.15$

547.04

542.57

$-531.64$

512.28

506.60

$-500.14$

$-483.89$

475.00

470.47

457.07

$-453.83$

$-450.52$

$-446.79$

$-441.96$

$-382.23$

$-374.81$

367.41

$-325.31$

325.31
320.27 
Figure S36. ${ }^{13} \mathrm{C}$ NMR spectrum of compound 4 in $\mathrm{CDCl}_{3}$.

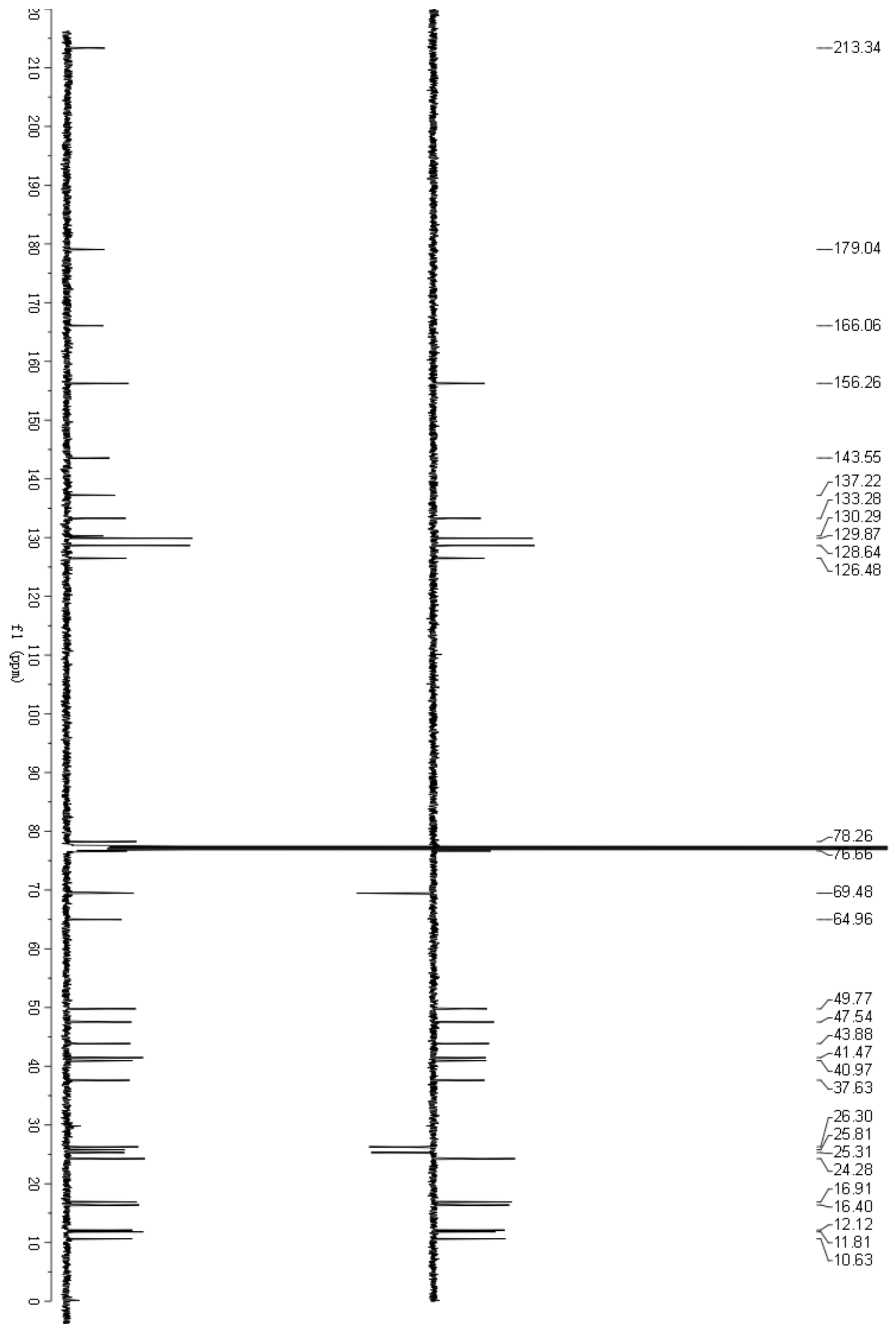


Figure S37. HSQC spectrum of compound 4 in $\mathrm{CDCl}_{3}$.

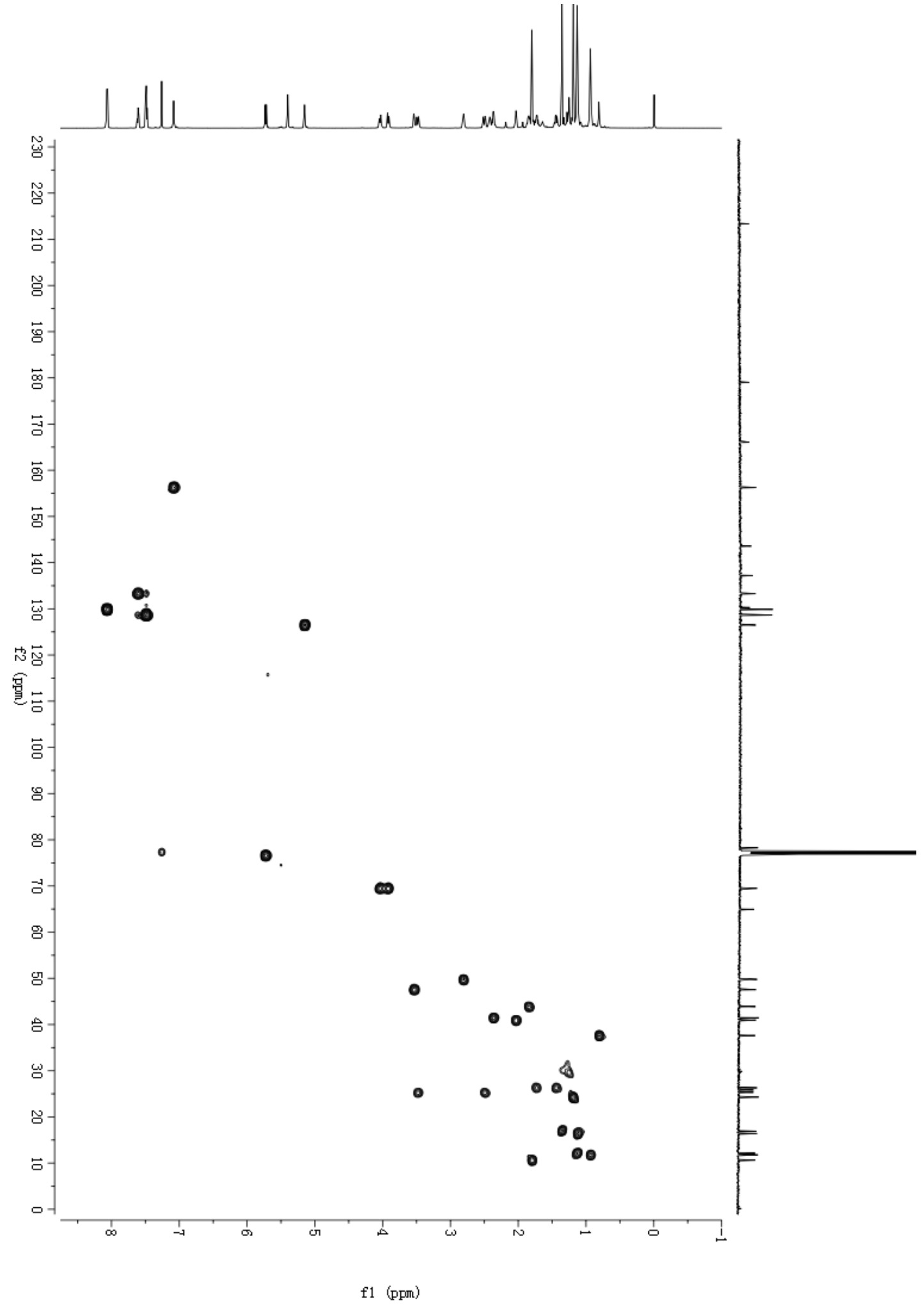


Figure S38. ${ }^{1} \mathrm{H}-{ }^{1} \mathrm{H}$ COSY spectrum of compound 4 in $\mathrm{CDCl}_{3}$.

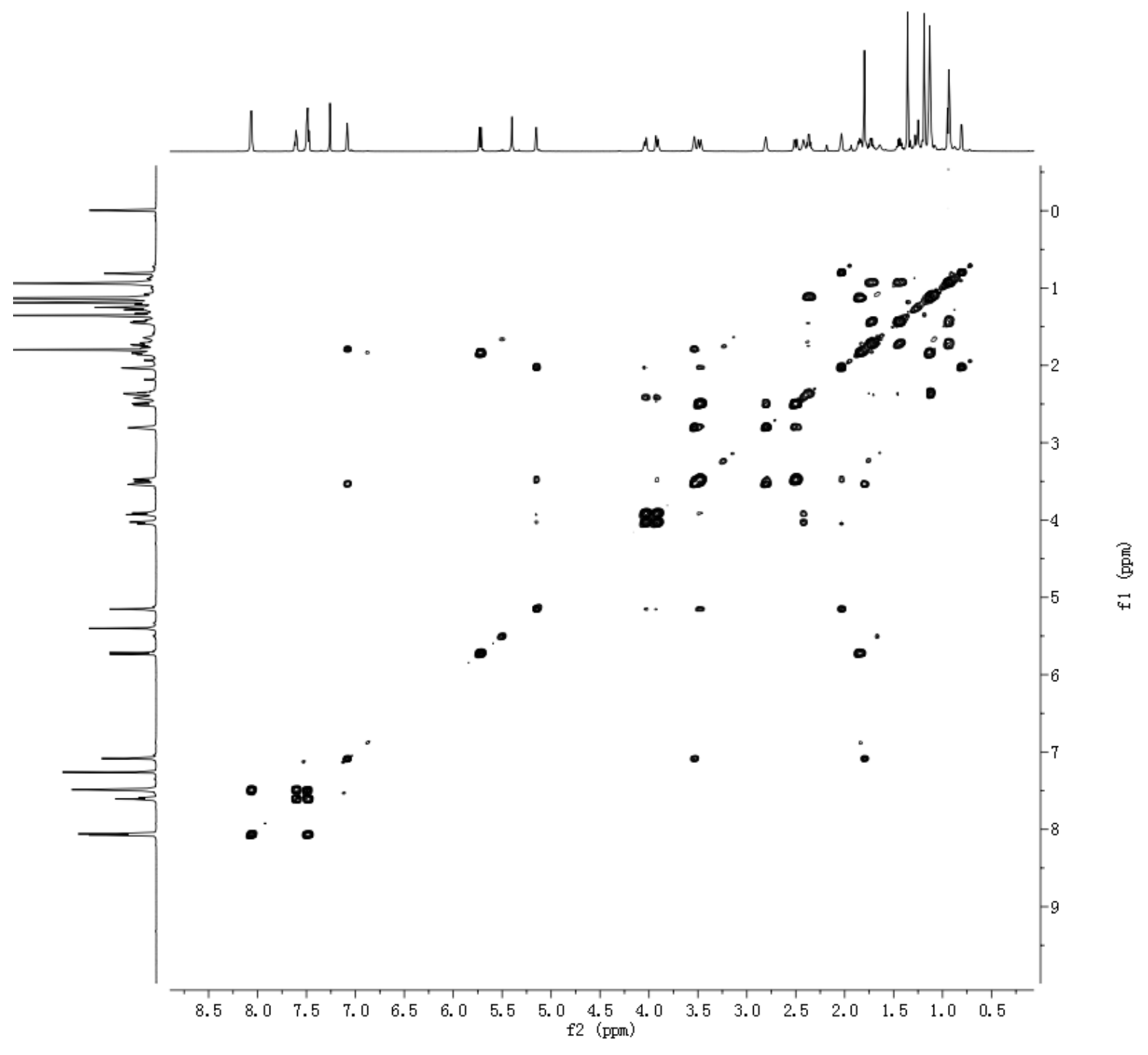


Figure S39. $\mathrm{HMBC}$ spectrum of compound 4 in $\mathrm{CDCl}_{3}$.

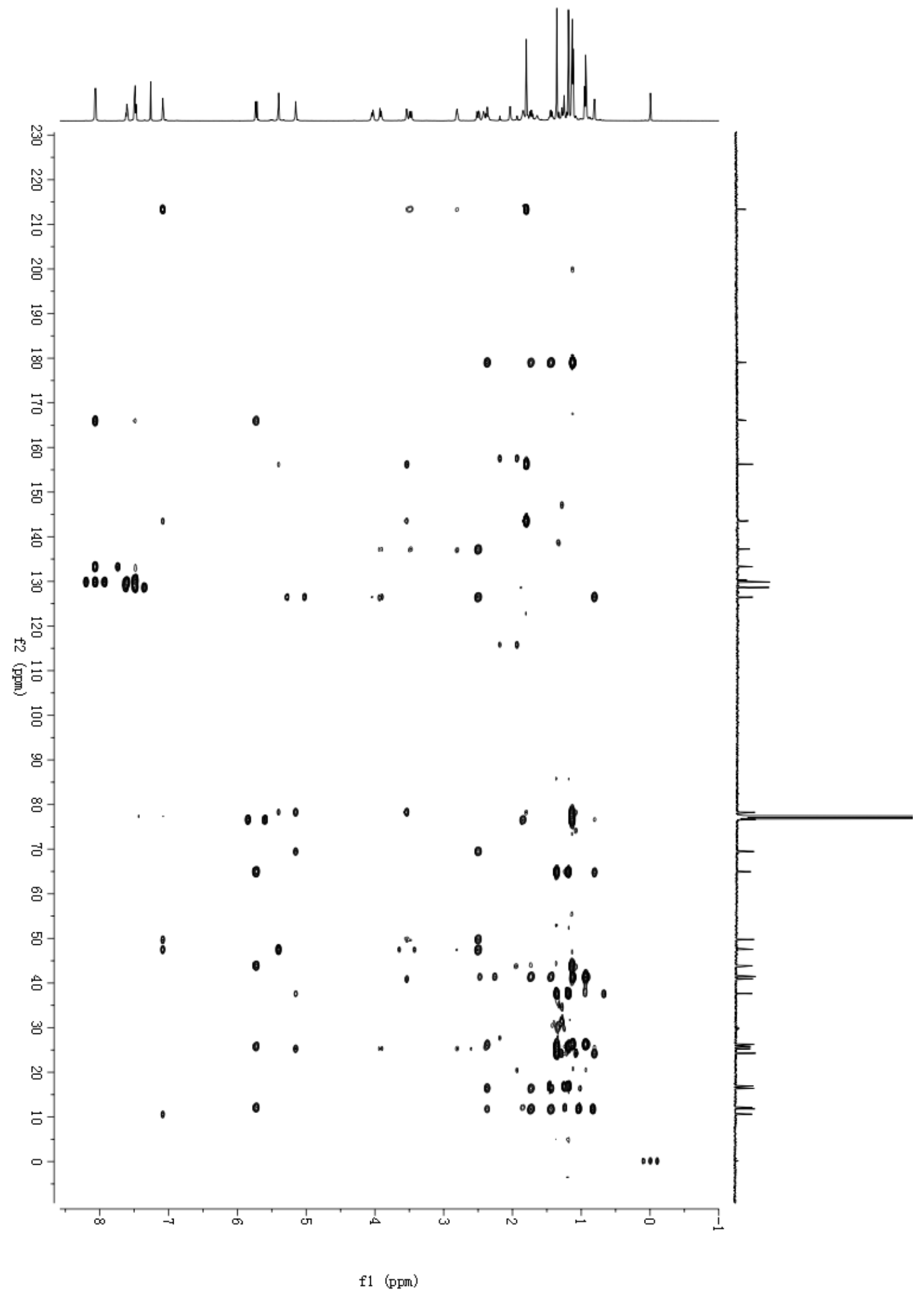


Figure S40. NOESY spectrum of compound 4 in $\mathrm{CDCl}_{3}$.

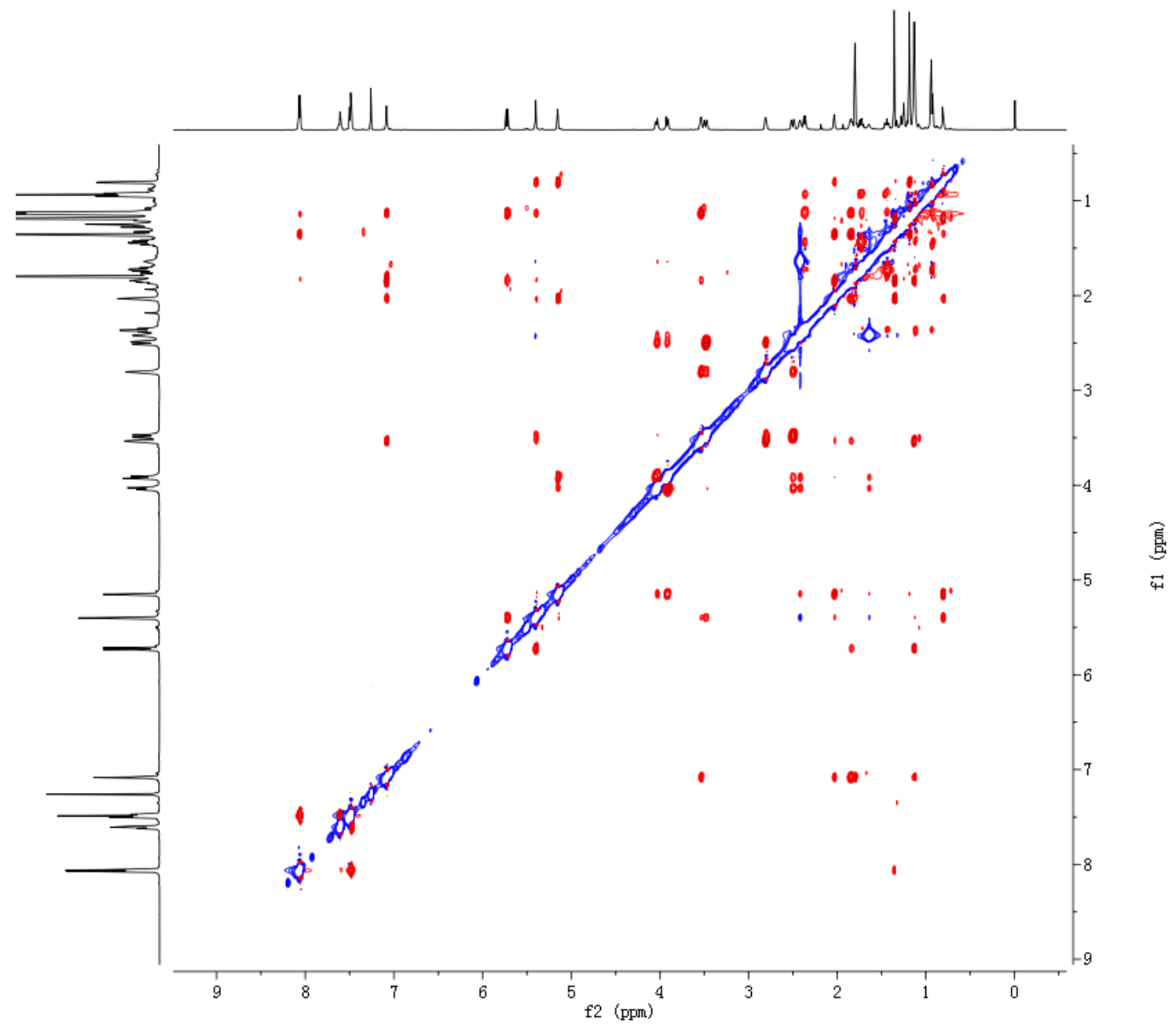


Figure S41. (+)-ESIMS spectrum of compound 4.

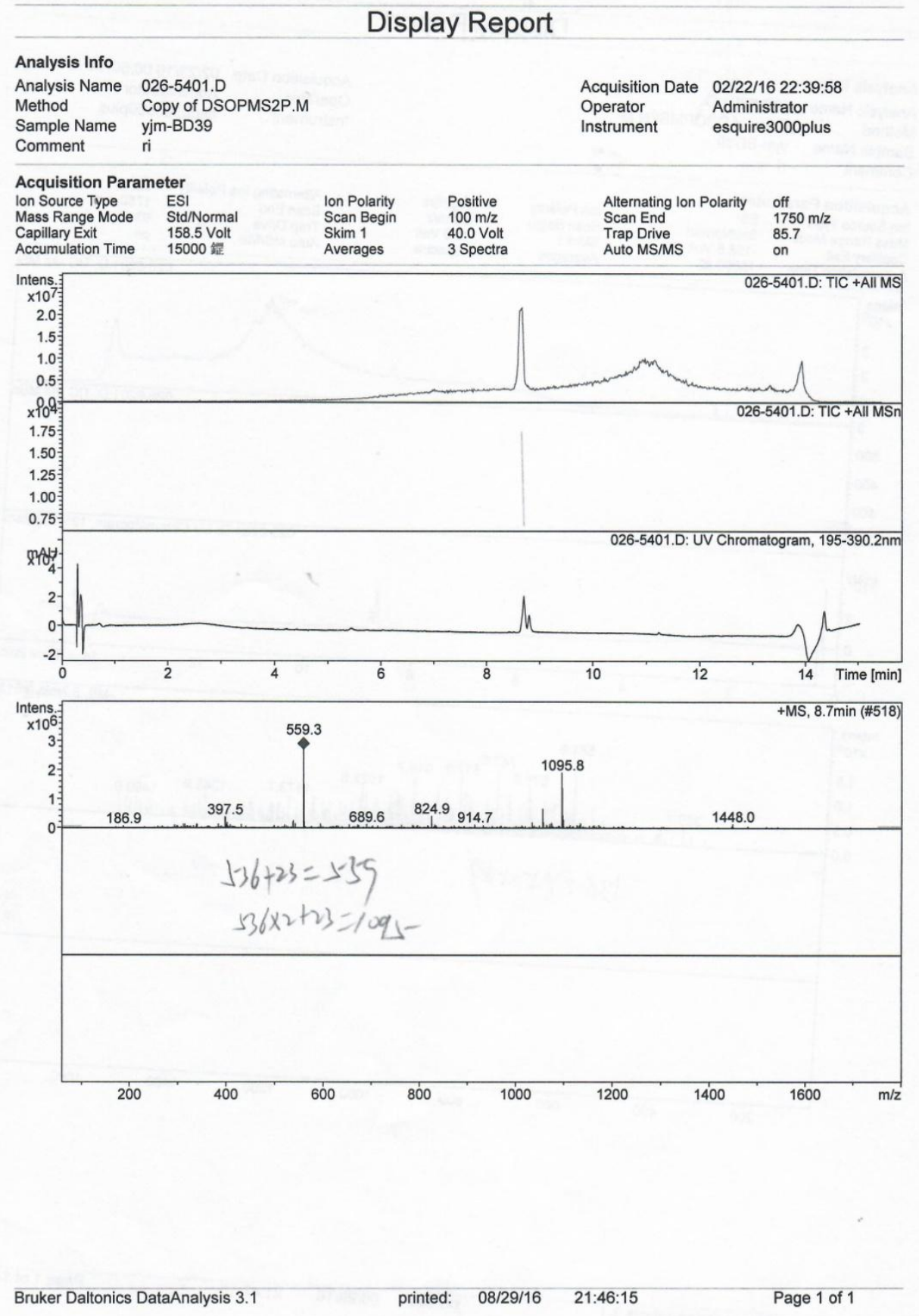


Figure S42. (-)-ESIMS spectrum of compound 4.

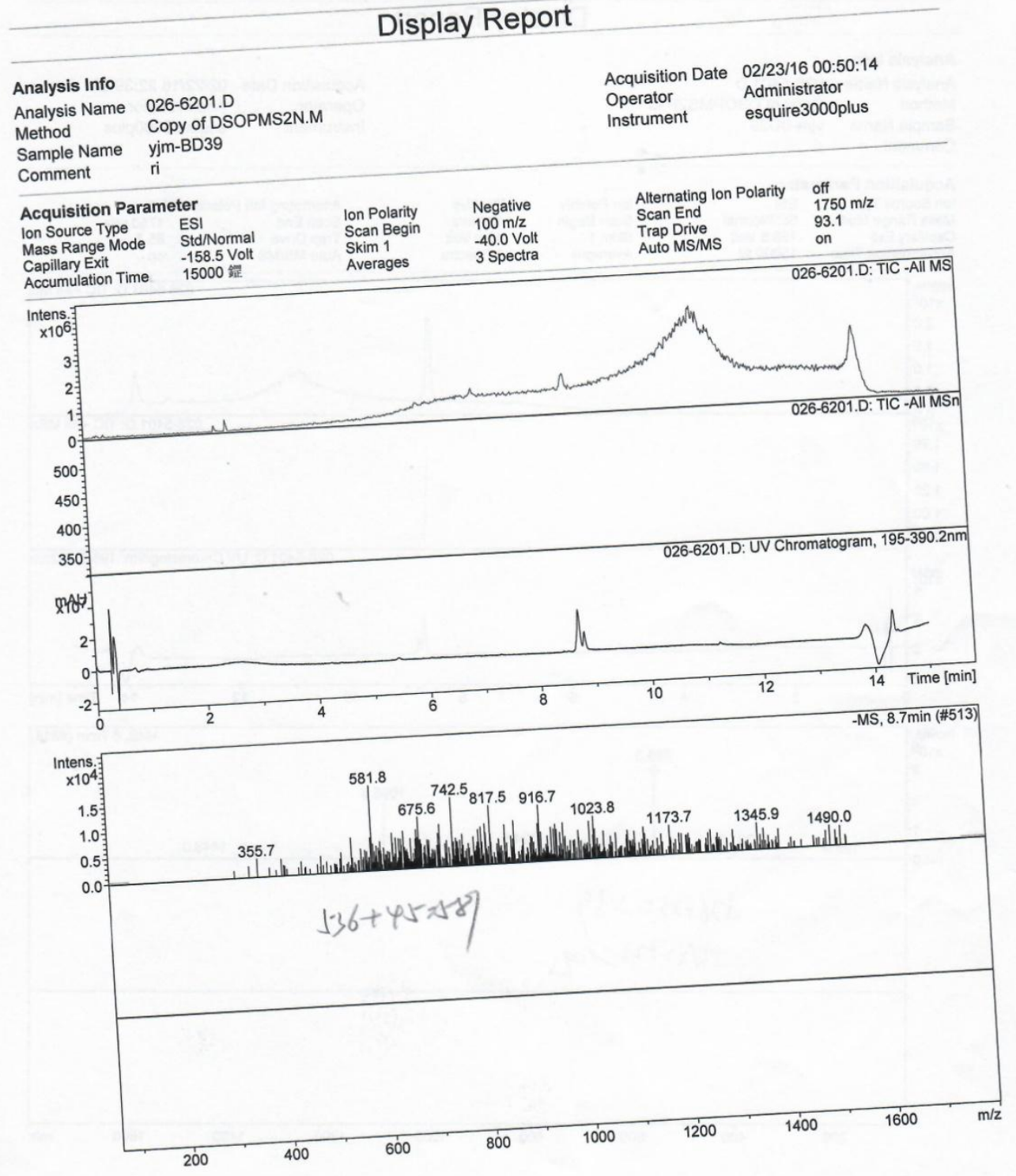

$\begin{array}{llll} & & \text { Page } 1 \text { of } 1\end{array}$


Figure S43. (+)-HRESIMS spectrum of compound 4.

Elemental Composition Report

Page 1

Single Mass Analysis

Tolerance $=3.0$ PPM / DBE: $\min =-1.5, \max =50.0$

Element prediction: Of

Number of isotope peaks used for $\mathrm{i}-\mathrm{FIT}=3$

Monoisotopic Mass, Even Electron lons

269 formula(e) evaluated with 1 results within limits (up to 50 best isotopic matches for each mass)

Elements Used:

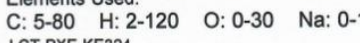

LCT PXE KE324

03-Jul-2017

$10: 18: 12$
$8 \mathrm{D} 3969(1.483) \mathrm{Cm}(68: 69)$

1: TOF MS ES+

$4.31 \mathrm{e}+003$

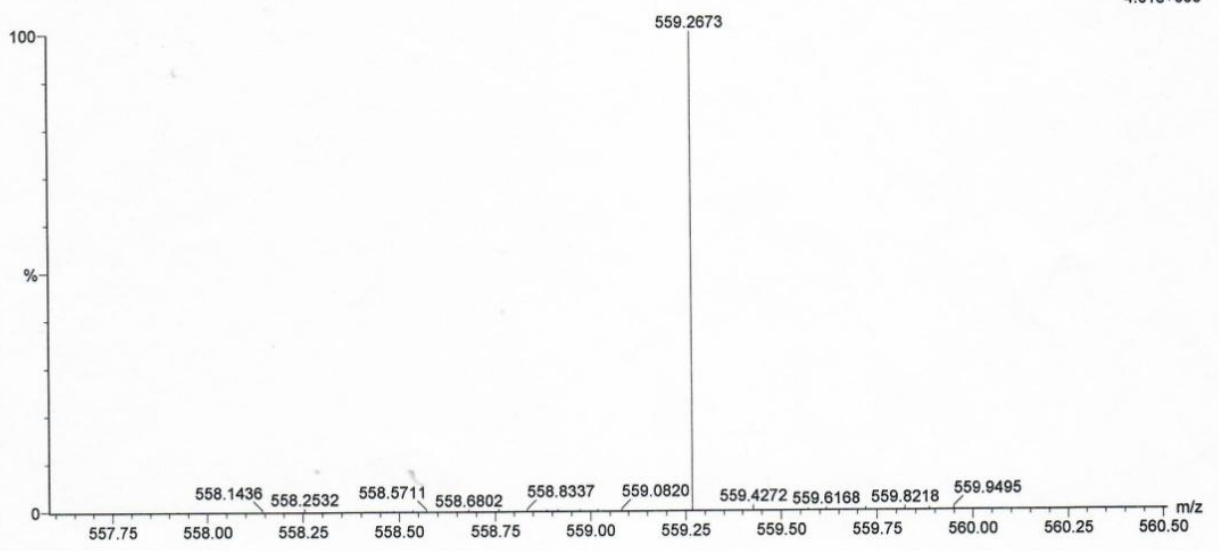

$\begin{array}{llll}\text { Minimum: } & & & -1.5 \\ \text { Maximum: } & 5.0 & 3.0 & 50.0\end{array}$

Mass Calc. Mass mDa PPM DBE i-FIT i-FIT (Norm) Formula

$\begin{array}{lllllllllll}559.2673 & 559.2672 & 0.1 & 0.2 & 12.5 & 67.7 & 0.0 & \text { C32 } & \text { H40 } & \text { 07 } & \text { Na }\end{array}$


Figure S44. IR spectrum of compound 4.

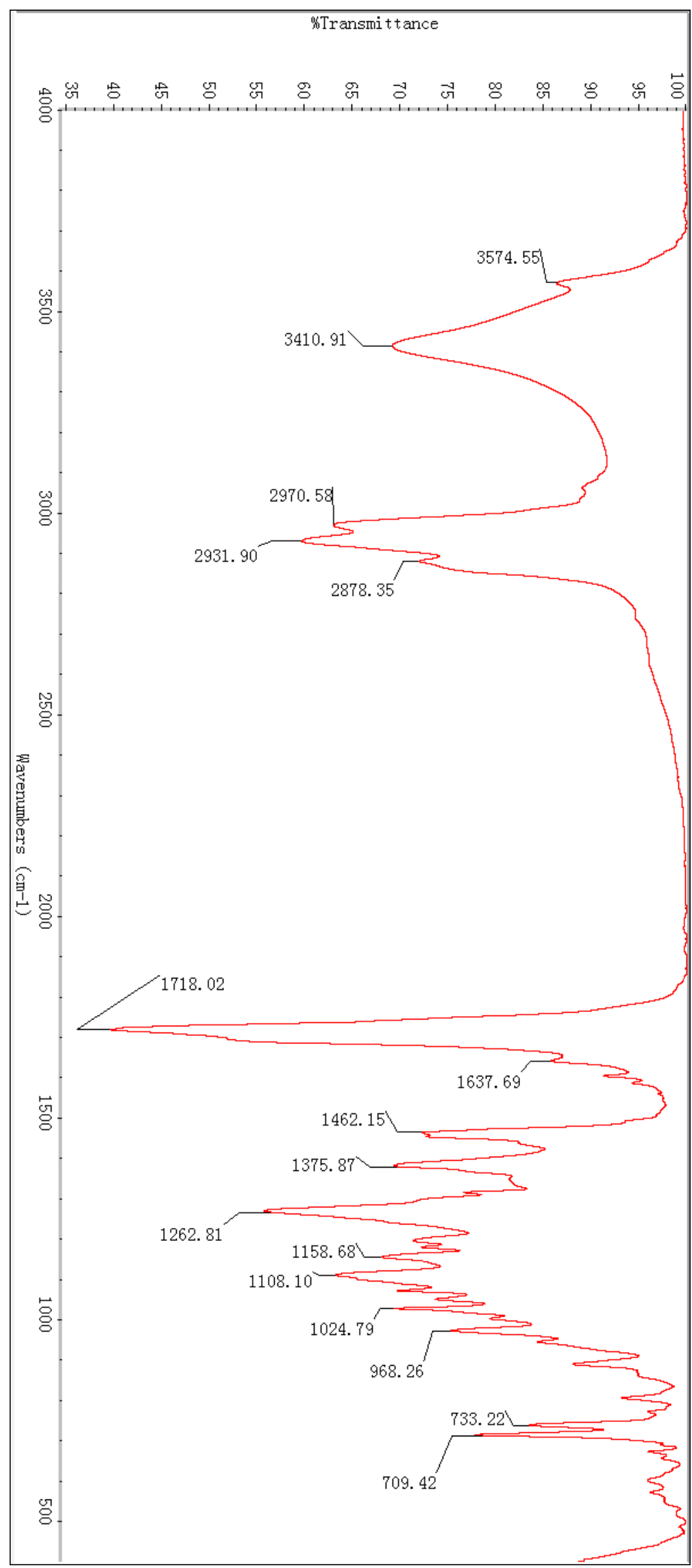


Figure S45. ${ }^{1} \mathrm{H}$ NMR spectrum of compound 5 in $\mathrm{CDCl}_{3}$.

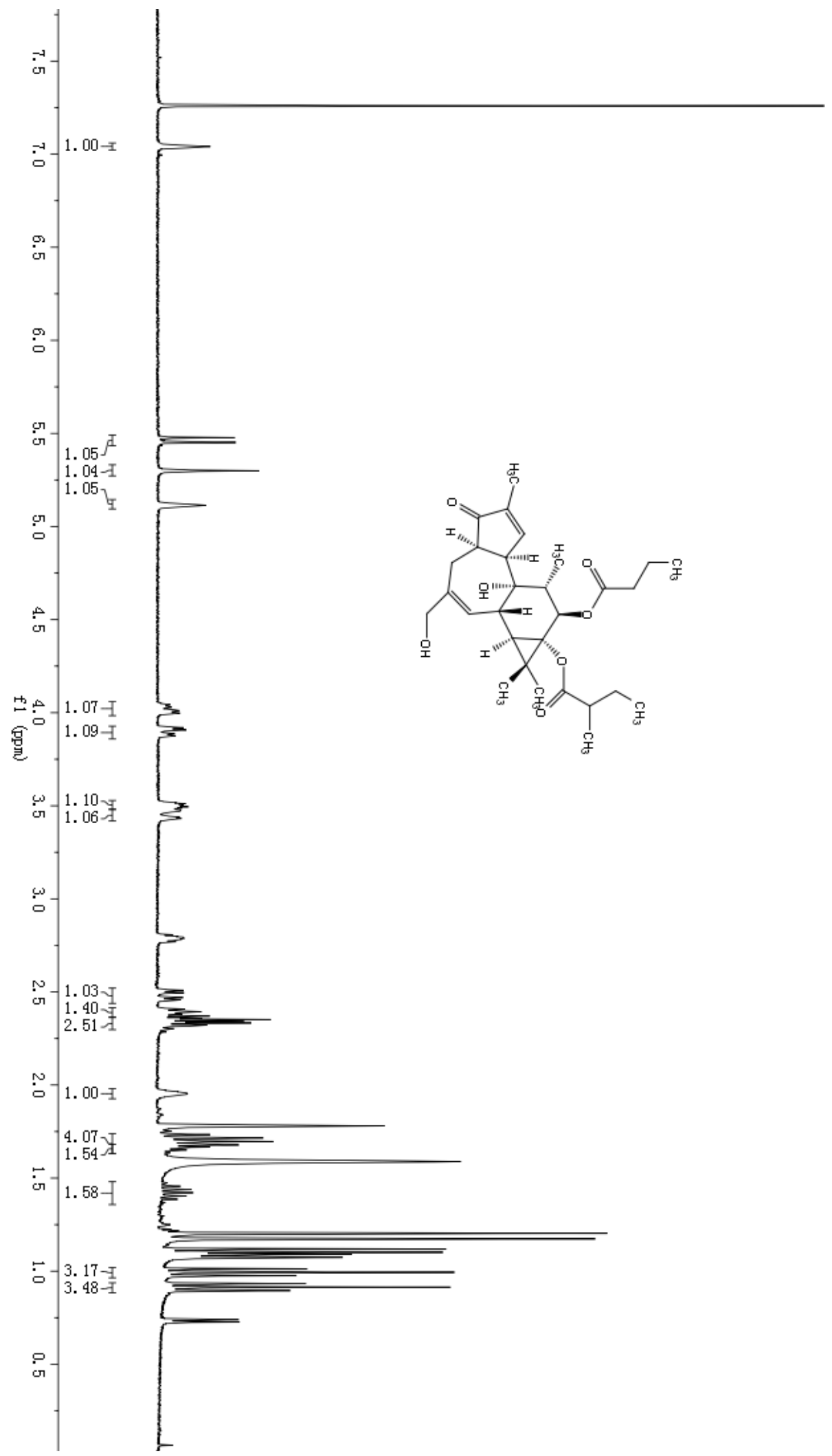

$<_{2817.68}^{2817.97}$

2191.81

2181.45

2120.54

2045.90

1617.68

$-1612.23$

$-1605.18$

1599.63

1567.96

1563.27

$-1555.64$

1550.86

1407.37

$-1404.95$

1402.58

$-1400.47$

$-1398.17$

1395.48

1389.59

1376.05

1372.97

1003.80

998.69

988.21

983.11

963.48

958.04

956.10

954.38

952.58

948.44

$-947.34$

94101

936.52

933.71

781.83

$-686.26$

$-678.88$

$-671.49$

$-582.92$

$-575.76$

$-568.76$

561.79

$-447.78$

$-446.02$

$-440.73$

438.63

$-436.26$

$-434.45$

429.86

$-426.90$

$-405.23$

$-397.82$

$-390.43$

$-373.29$

$-365.86$

-358.40 
Figure S46. ${ }^{13} \mathrm{C}$ NMR spectrum of compound 5 in $\mathrm{CDCl}_{3}$.

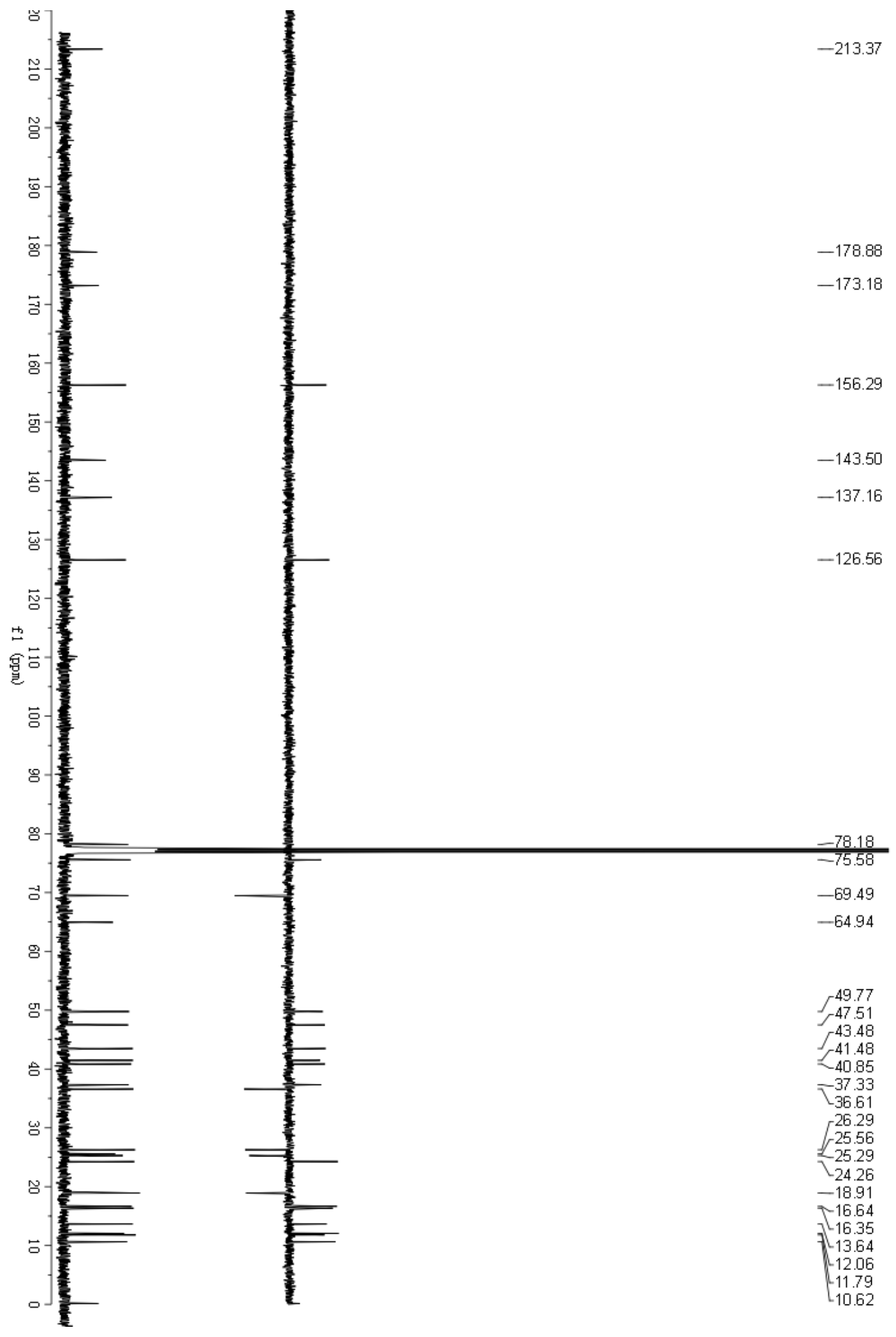


Figure S47. HSQC spectrum of compound 5 in $\mathrm{CDCl}_{3}$.

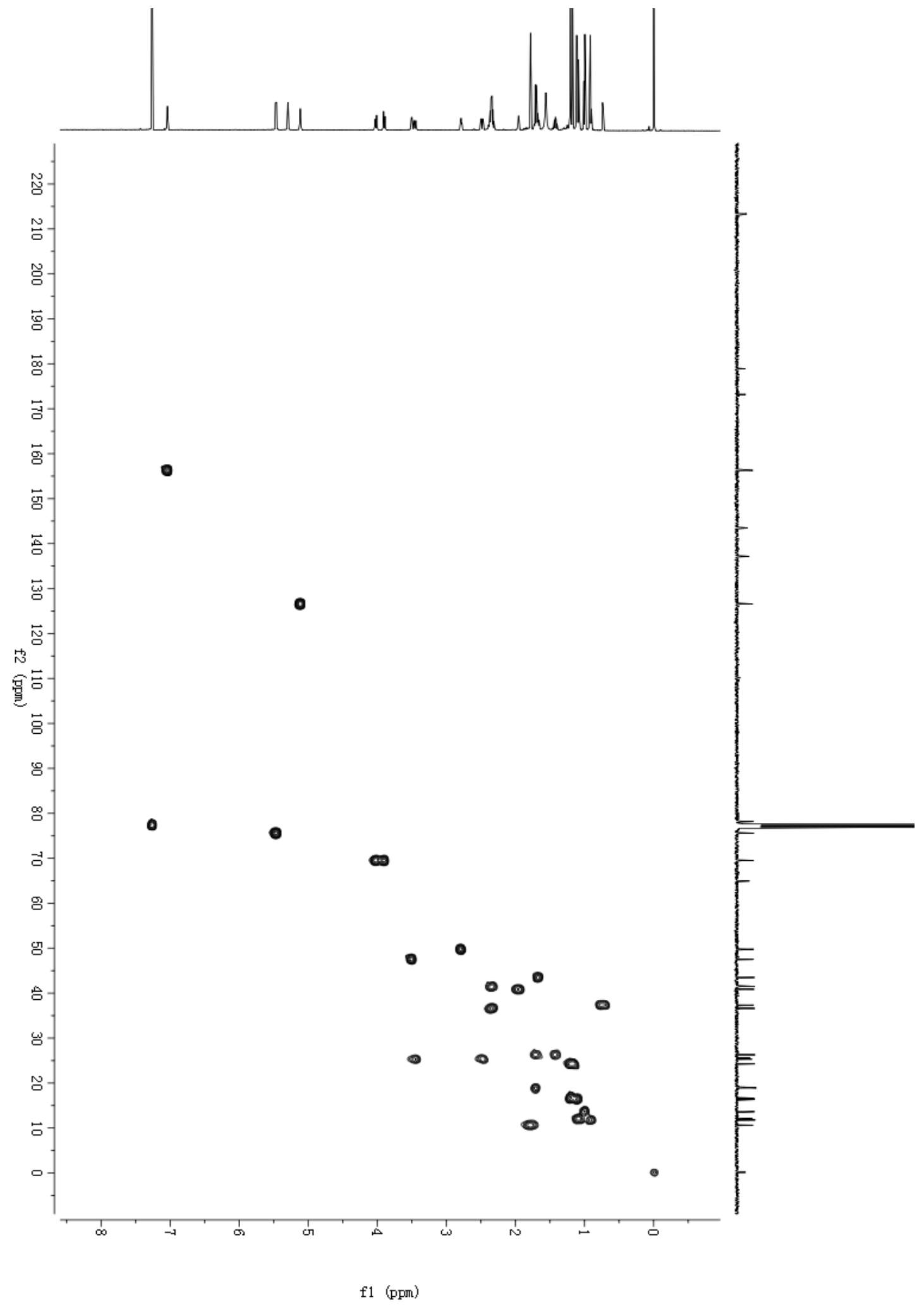


Figure S48. ${ }^{1} \mathrm{H}-{ }^{1} \mathrm{H}$ COSY spectrum of compound 5 in $\mathrm{CDCl}_{3}$.

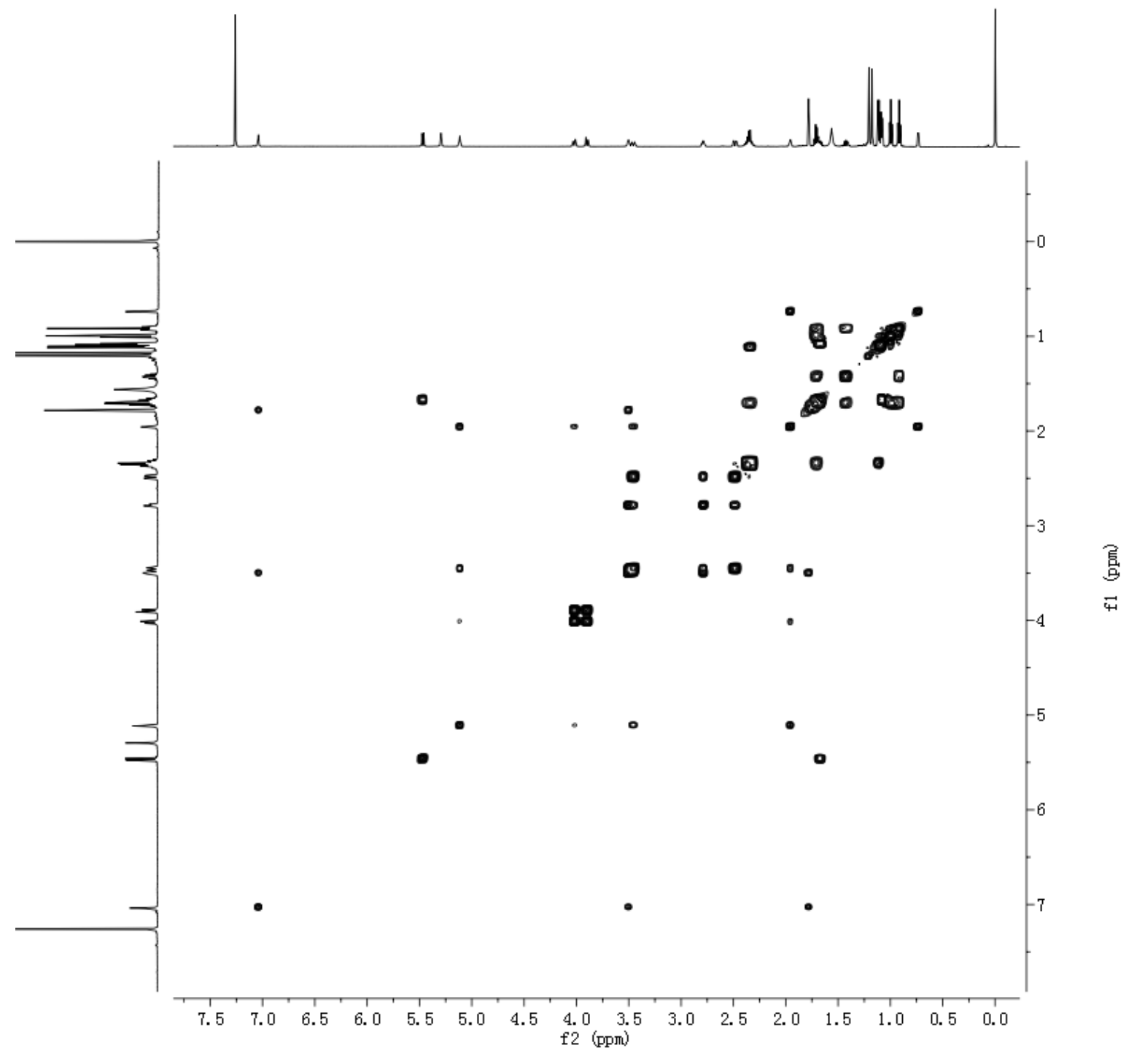


Figure S49. $\mathrm{HMBC}$ spectrum of compound 5 in $\mathrm{CDCl}_{3}$.

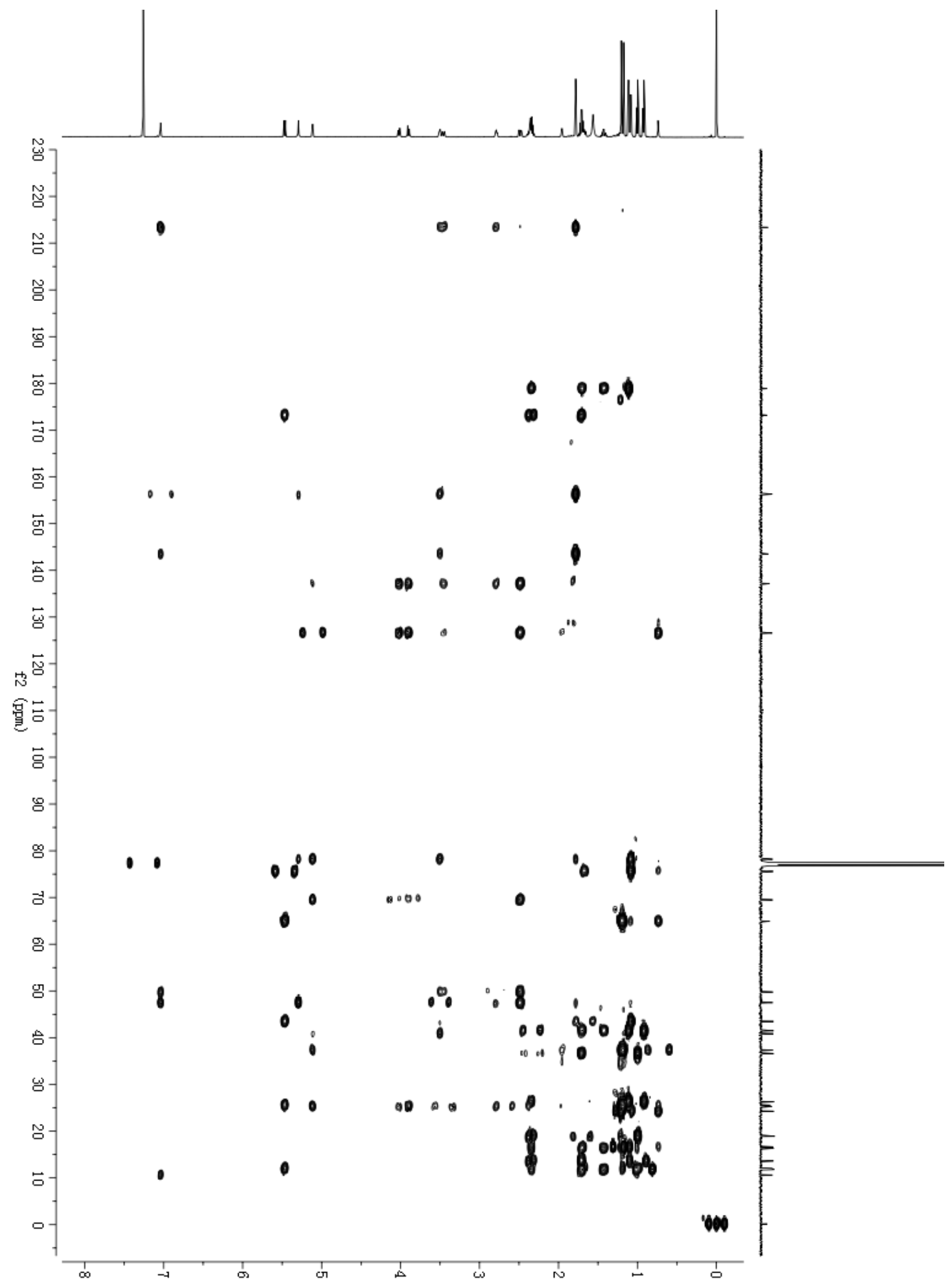

f1 (ppm) 
Figure S50. NOESY spectrum of compound $\mathbf{5}$ in $\mathrm{CDCl}_{3}$.

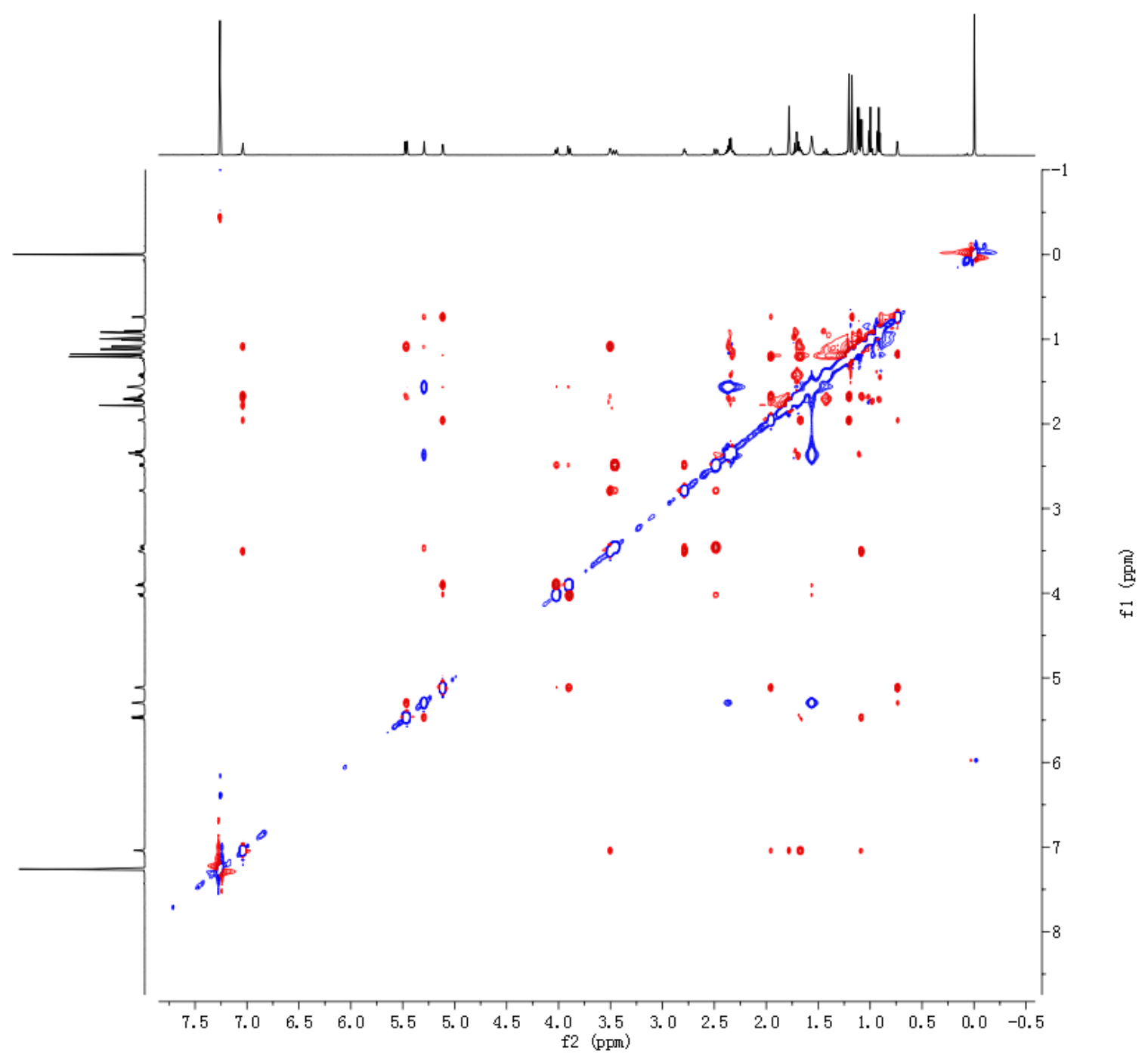


Figure S51. (+)-ESIMS spectrum of compound 5.

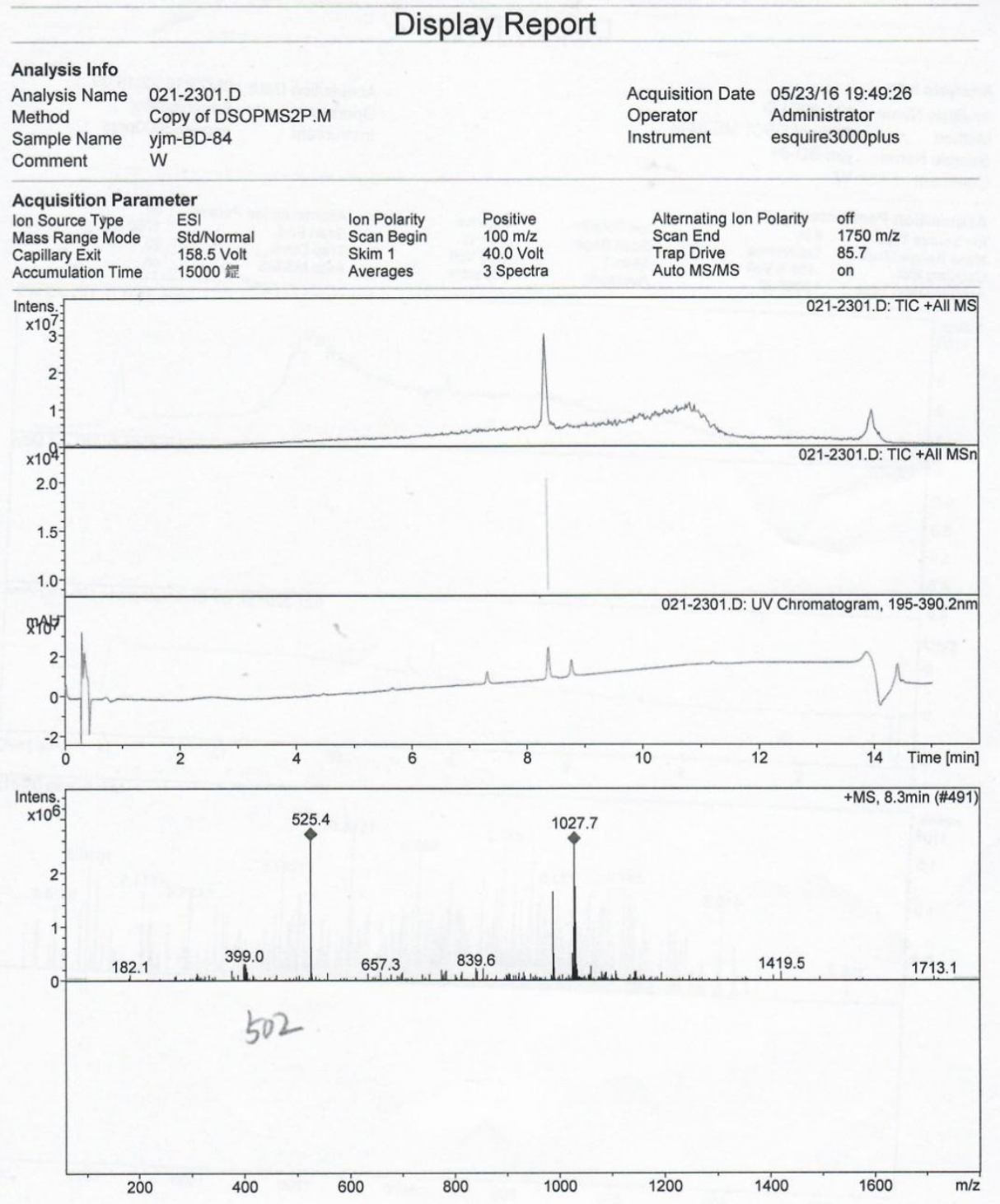


Figure S52. (+)-HRESIMS spectrum of compound 5.

Single Mass Analysis

Tolerance $=1.0$ PPM I DBE: $\min =-1.5, \max =50.0$

Element prediction: Off

Number of isotope peaks used for i-FIT $=3$

Monoisotopic Mass, Even Electron lons

242 formula(e) evaluated with 1 results within limits (up to 50 best isotopic matches for each mass)

Elements Used:

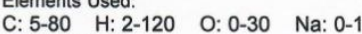

LCT PXE KE 324

29-Jun-2017

$18: 34: 23$
BD84 $34(0.725) \mathrm{Cm}(34: 40)$

1: TOF MS ES+

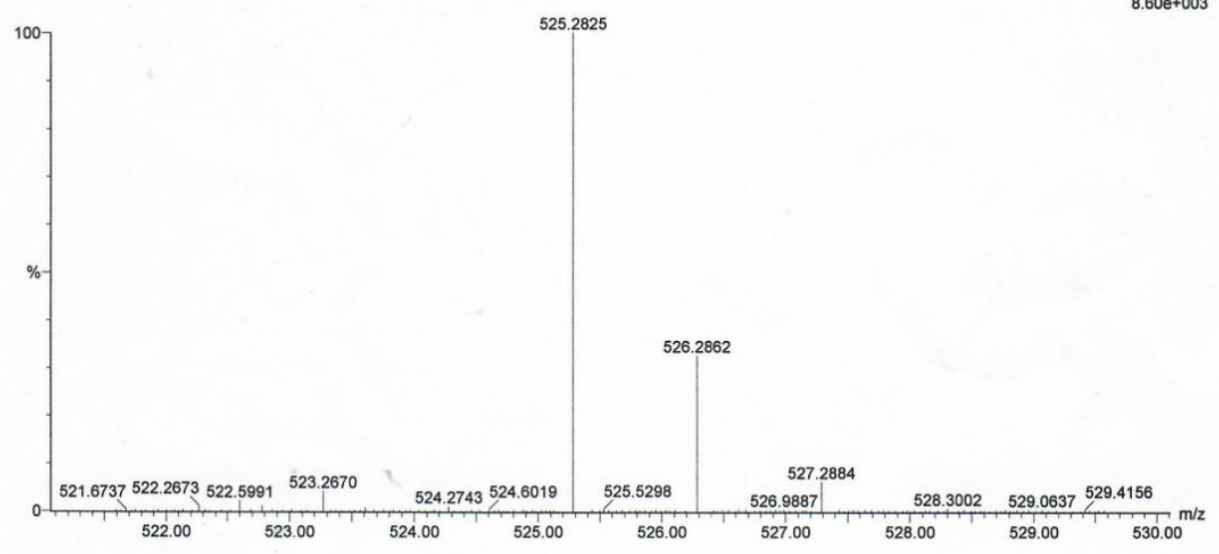

Minimum:

Mass Calc. Mass mDa PPM DBE i-FIT i-FIT (Norm) Formula

$\begin{array}{lllllllllll}525.2825 & 525.2828 & -0.3 & -0.6 & 8.5 & 239.1 & 0.0 & \text { C29 } & \text { H42 } & 07 & \text { Na }\end{array}$ 
Figure S53. IR spectrum of compound 5.

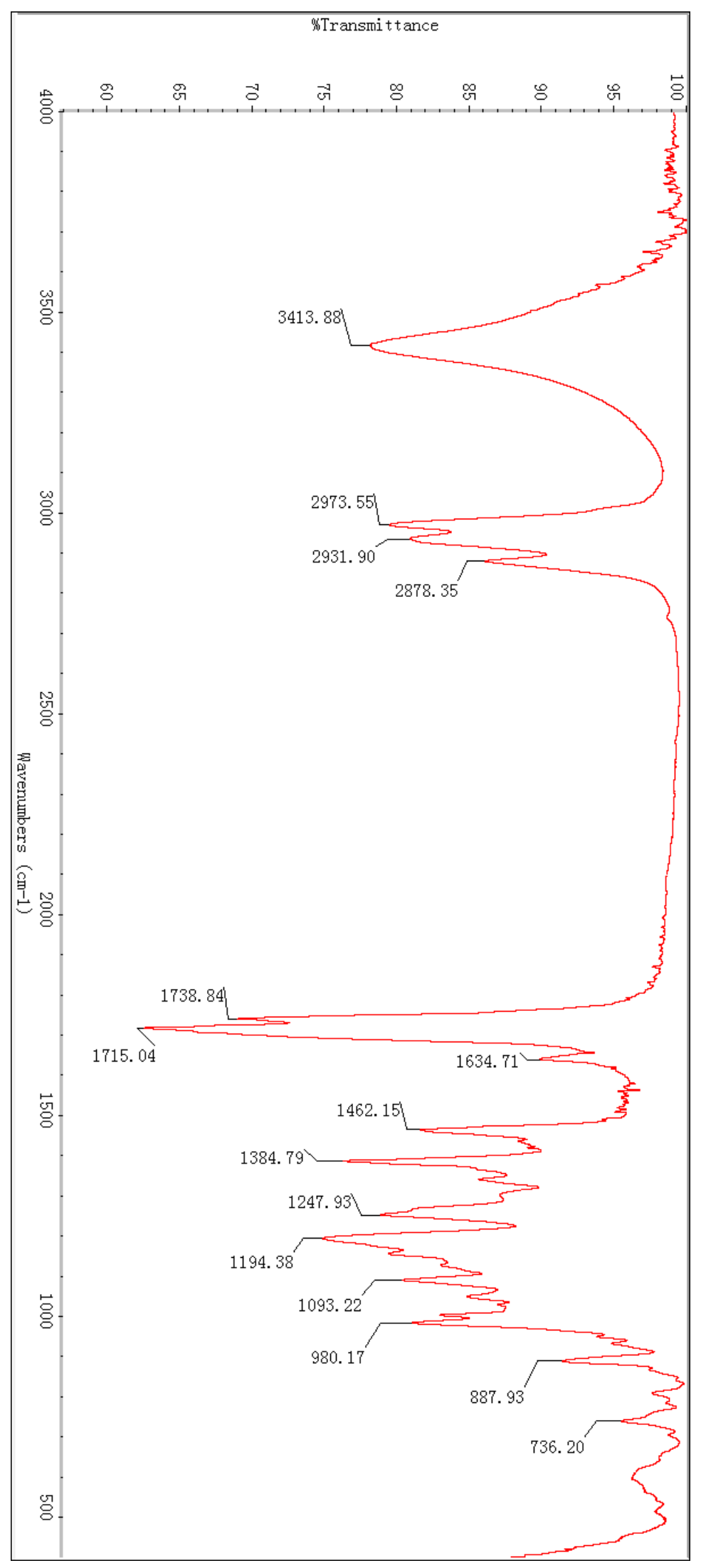


Figure S54. ${ }^{1} \mathrm{H}$ NMR spectrum of compound 6 in $\mathrm{CDCl}_{3}$.

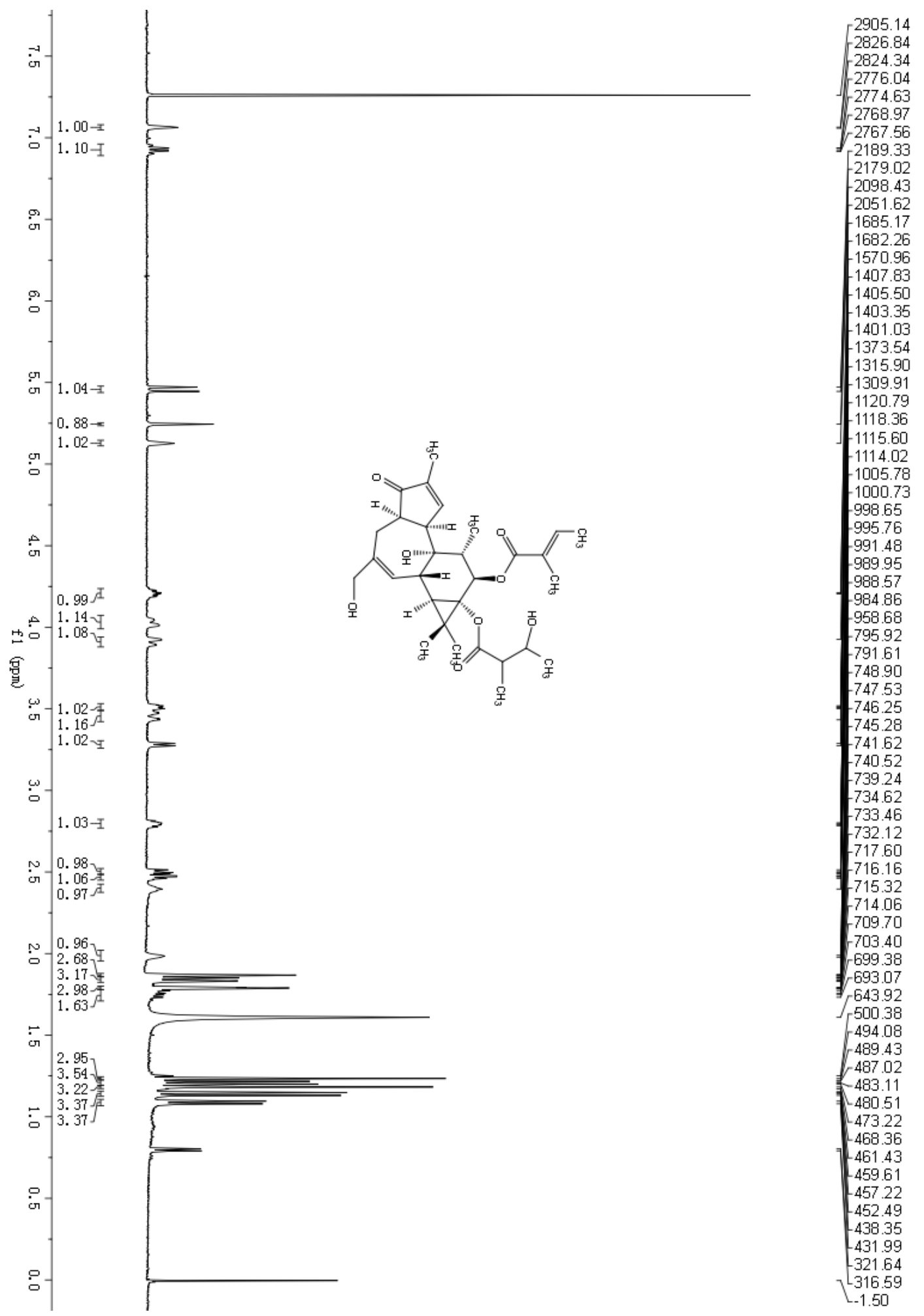


Figure S55. ${ }^{13} \mathrm{C}$ NMR spectrum of compound 6 in $\mathrm{CDCl}_{3}$.

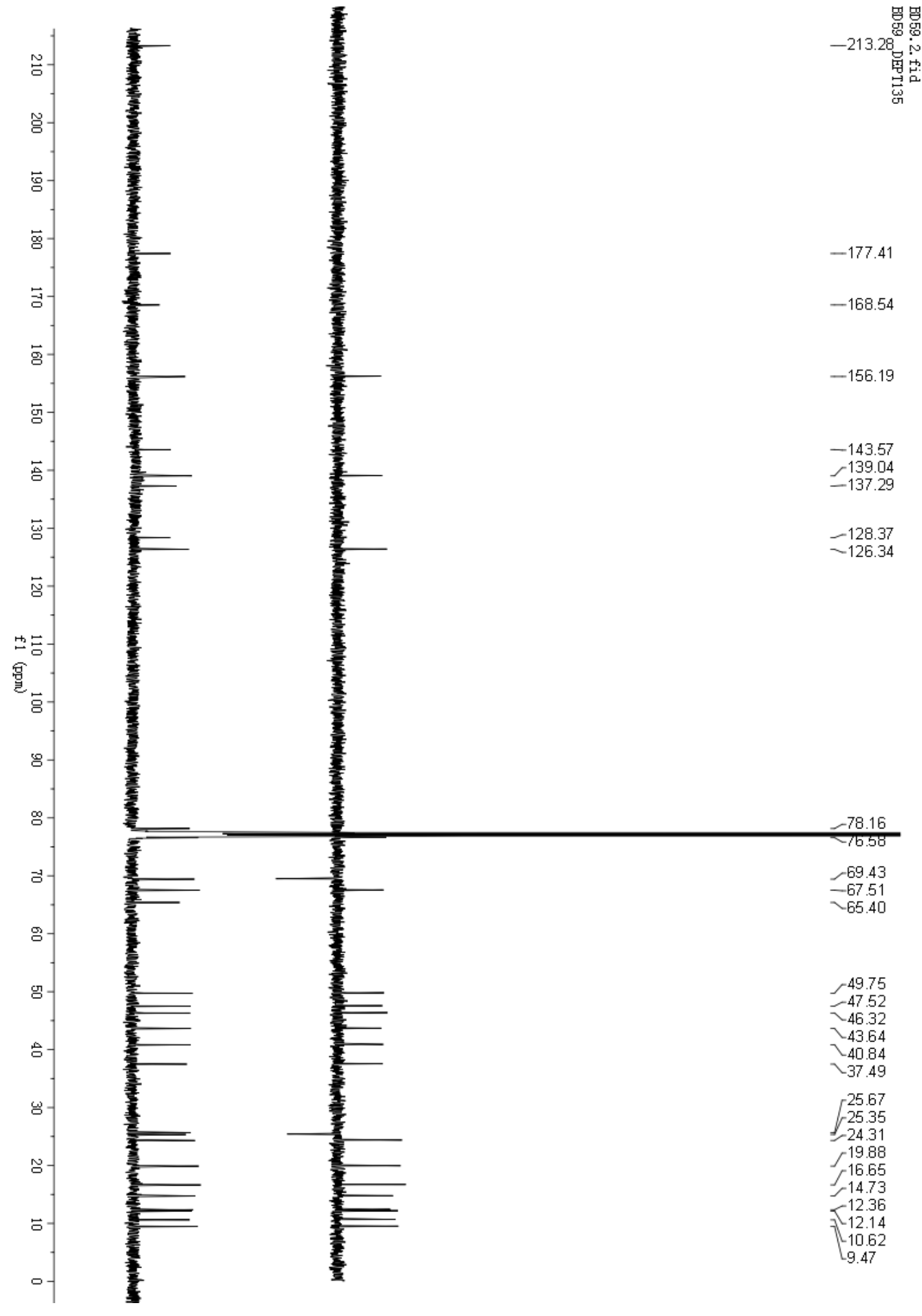


Figure S56. HSQC spectrum of compound 6 in $\mathrm{CDCl}_{3}$.

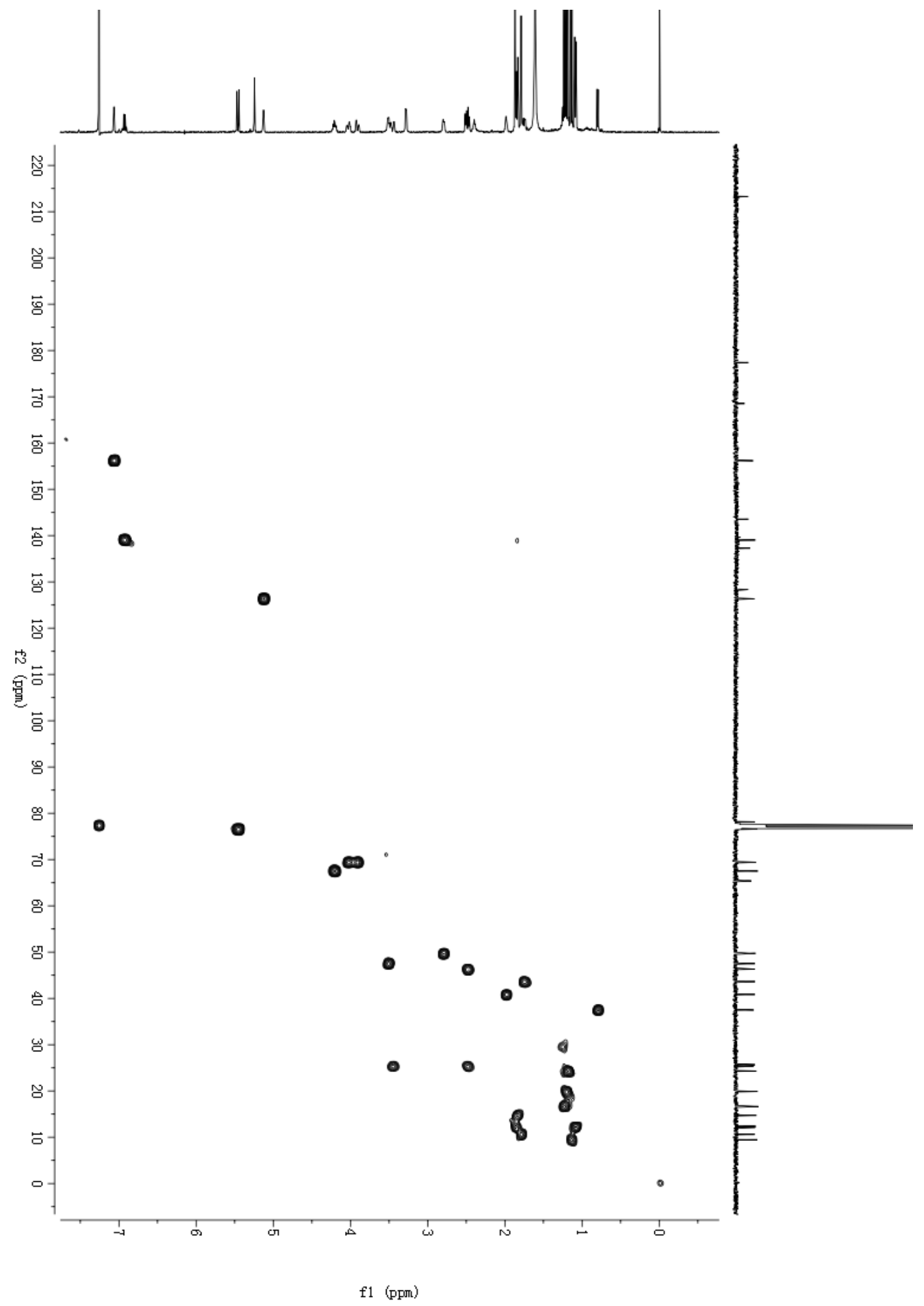


Figure S57. ${ }^{1} \mathrm{H}-{ }^{1} \mathrm{H}$ COSY spectrum of compound 6 in $\mathrm{CDCl}_{3}$.

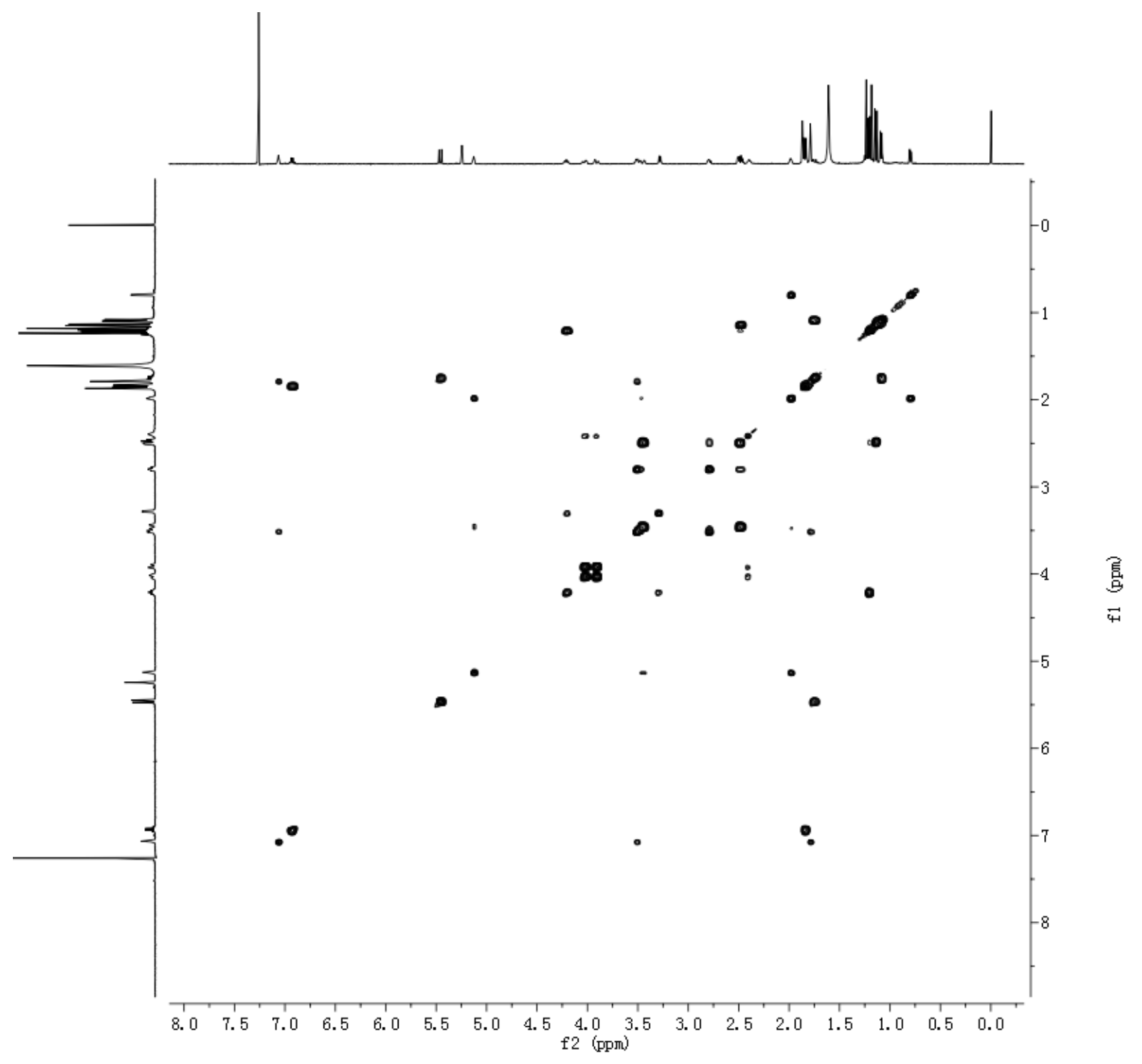


Figure S58. $\mathrm{HMBC}$ spectrum of compound $\mathbf{6}$ in $\mathrm{CDCl}_{3}$.

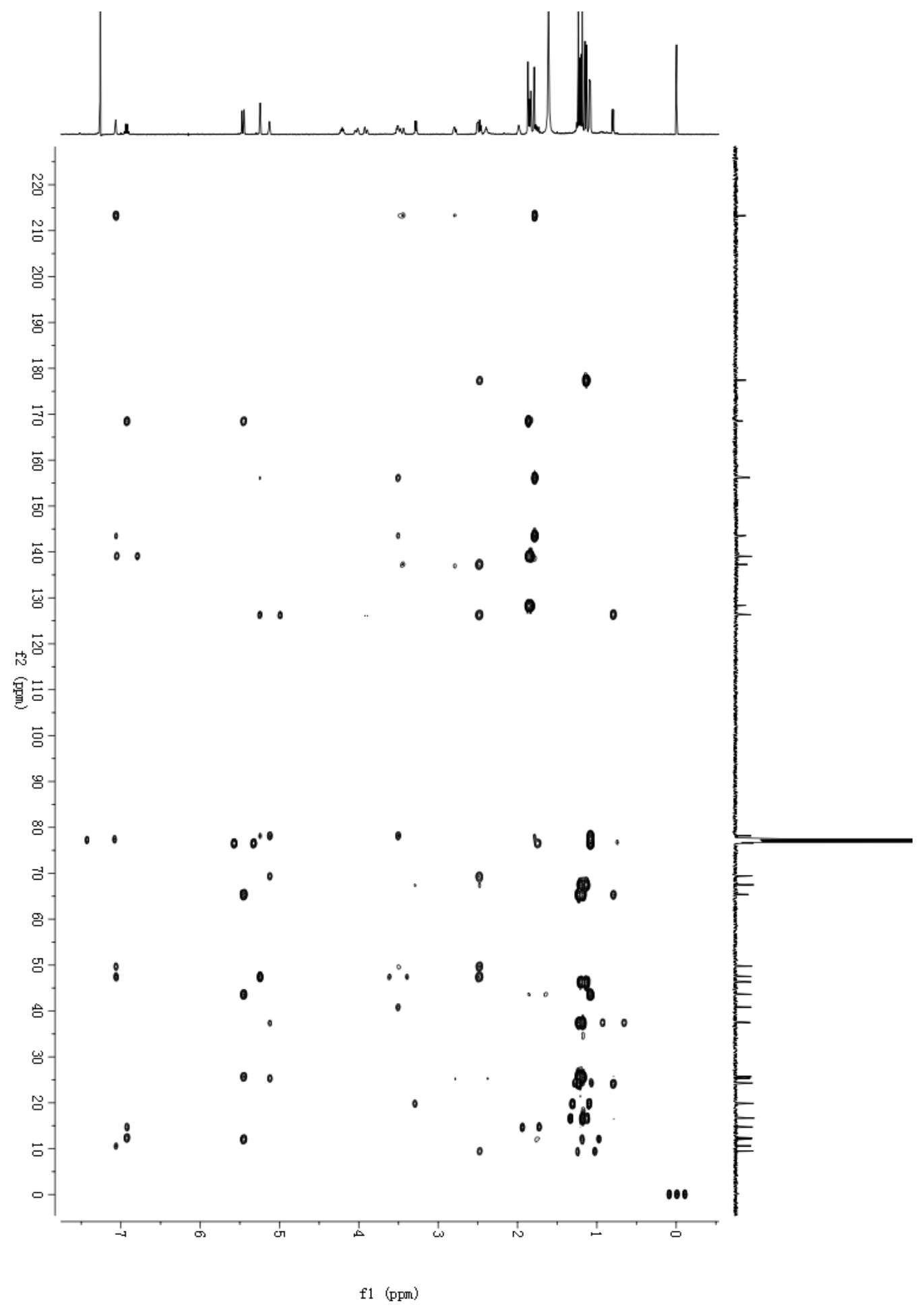


Figure S59. NOESY spectrum of compound $\mathbf{6}$ in $\mathrm{CDCl}_{3}$.

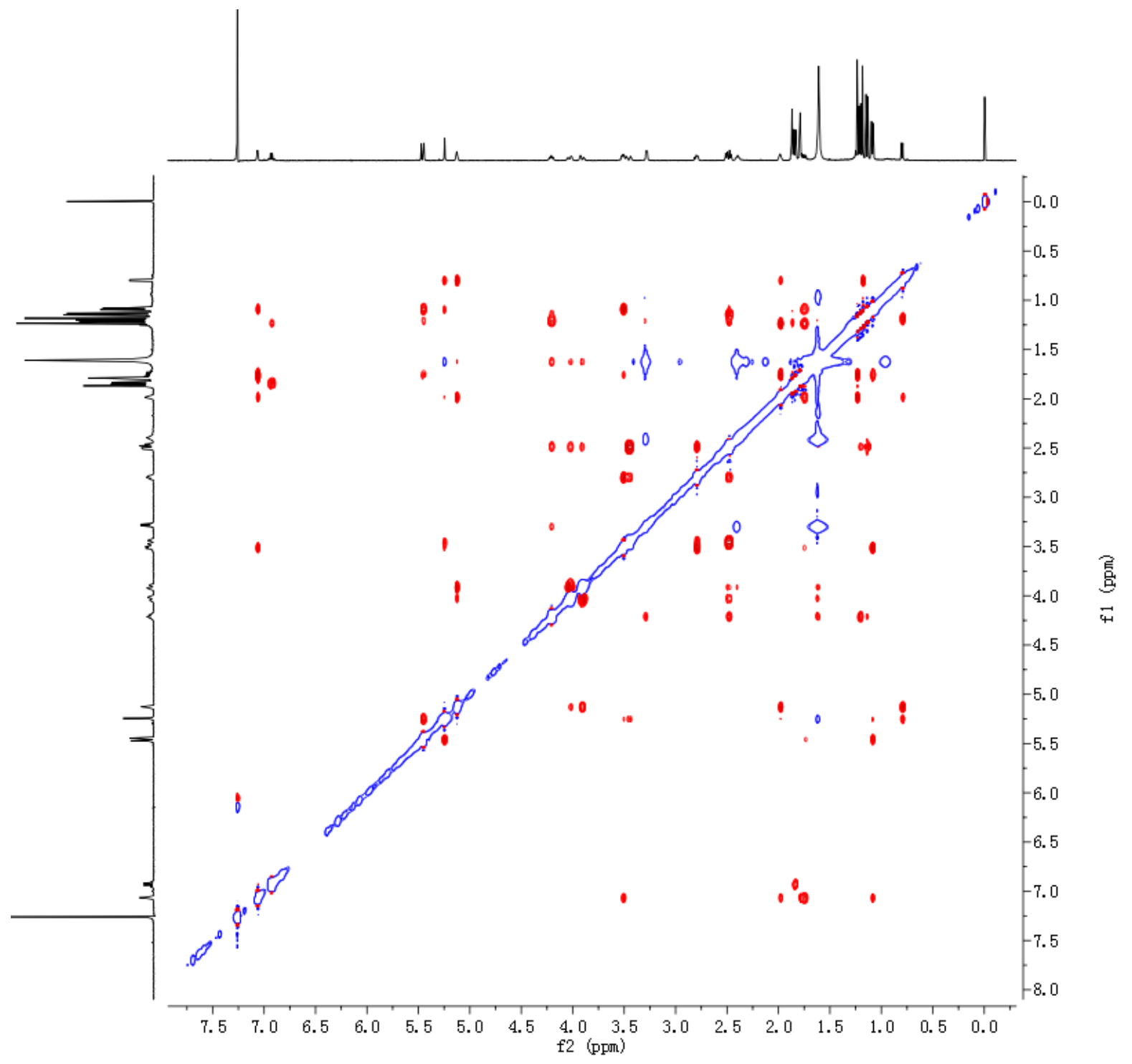


Figure S60. (+)-ESIMS spectrum of compound 6.

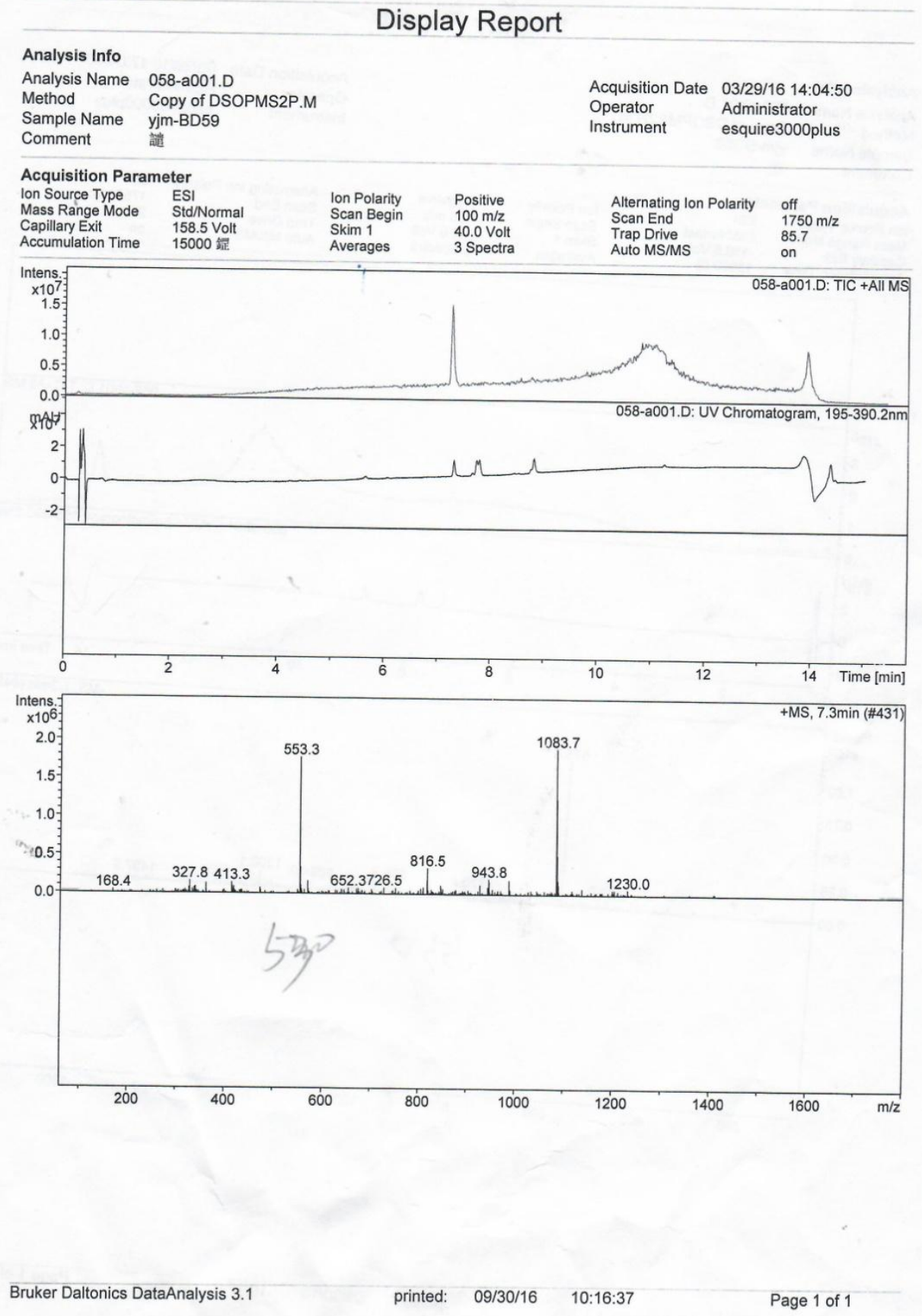


Figure S61. (-)-ESIMS spectrum of compound 6.

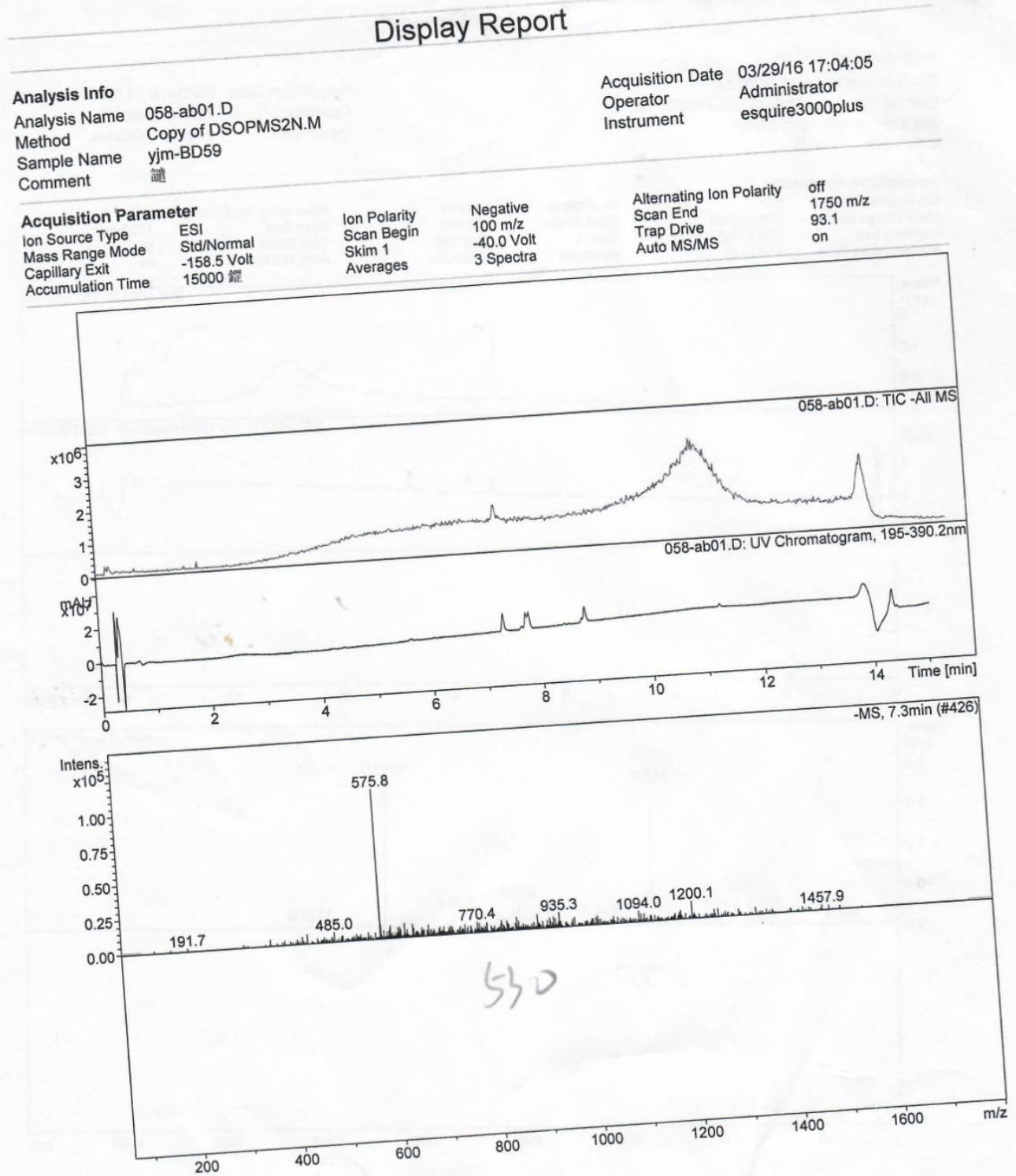

$\begin{array}{llll} & & & \text { Page } 1 \text { of } 1\end{array}$


Figure S62. (+)-HRESIMS spectrum of compound 6.

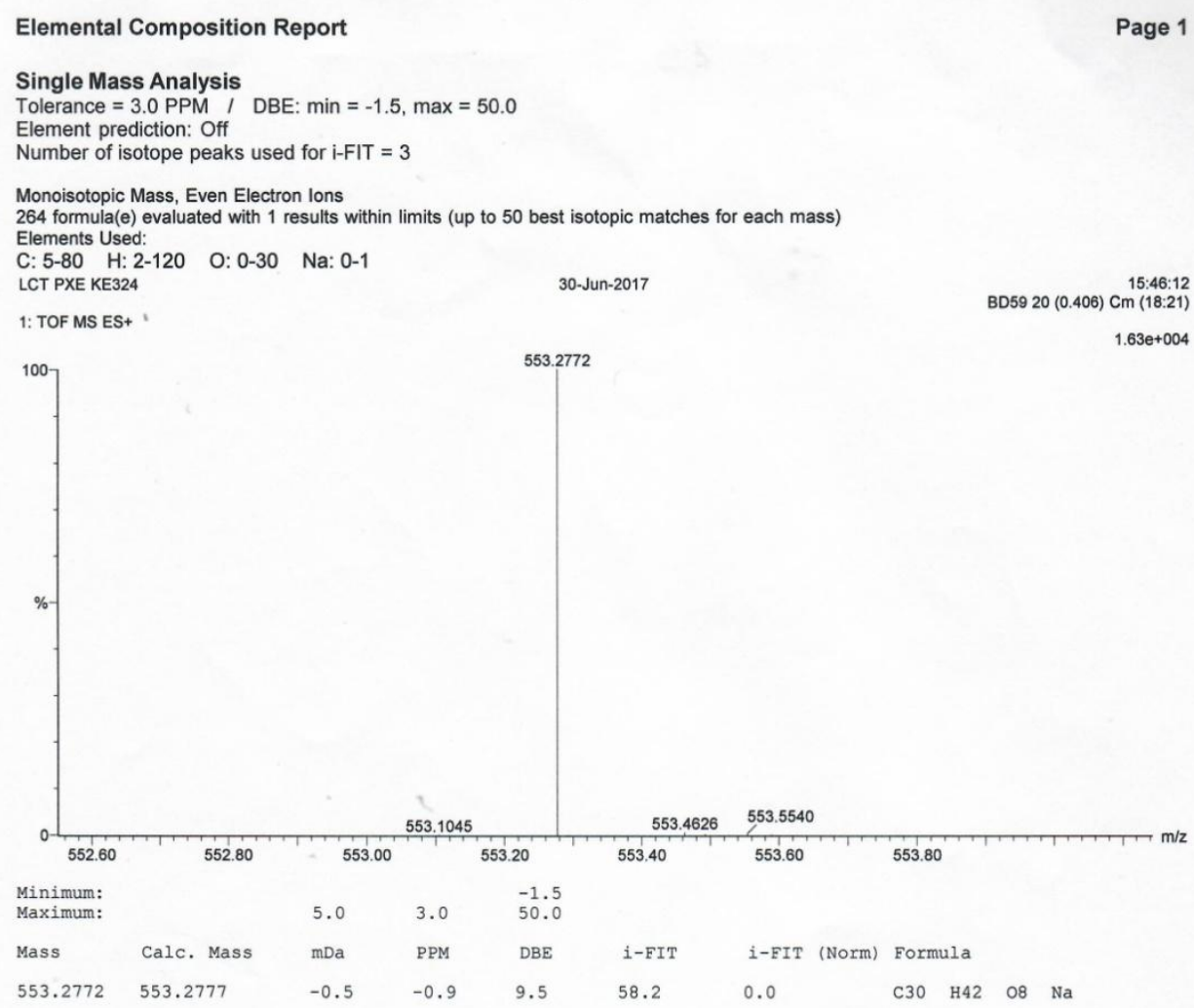


Figure S63. IR spectrum of compound 6.

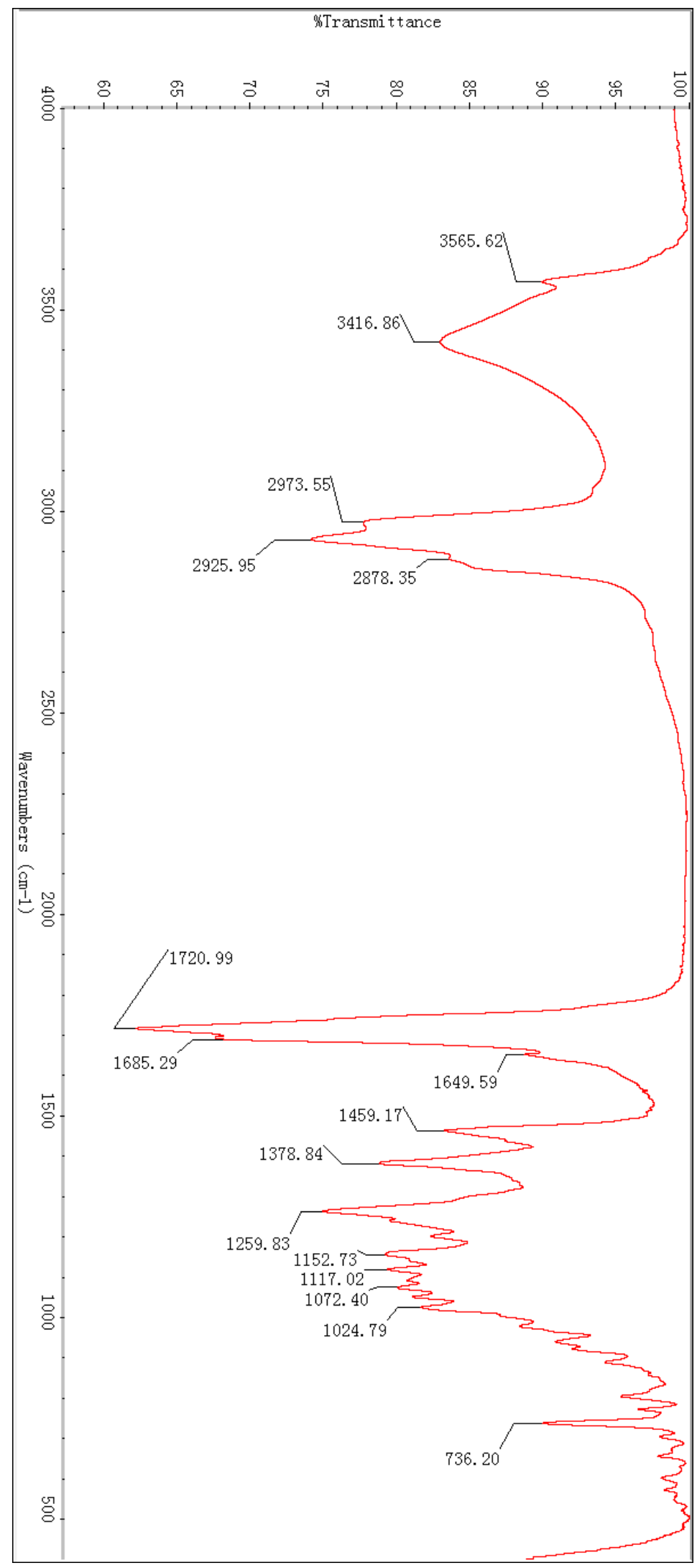


Figure S64. ${ }^{1} \mathrm{H}$ NMR spectrum of compound 7 in $\mathrm{CDCl}_{3}$.

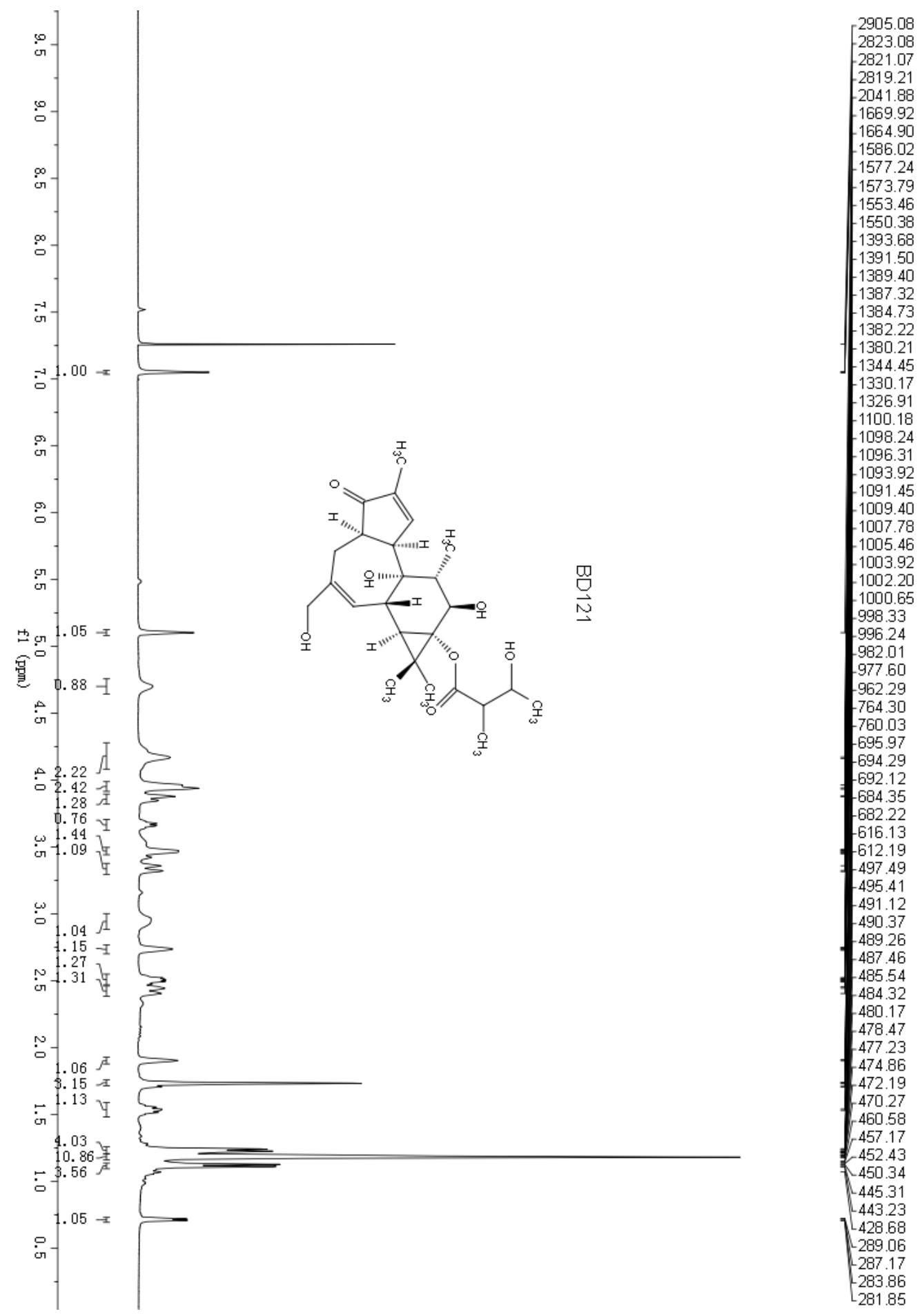


Figure S65. ${ }^{13} \mathrm{C}$ NMR spectrum of compound 7 in $\mathrm{CDCl}_{3}$.
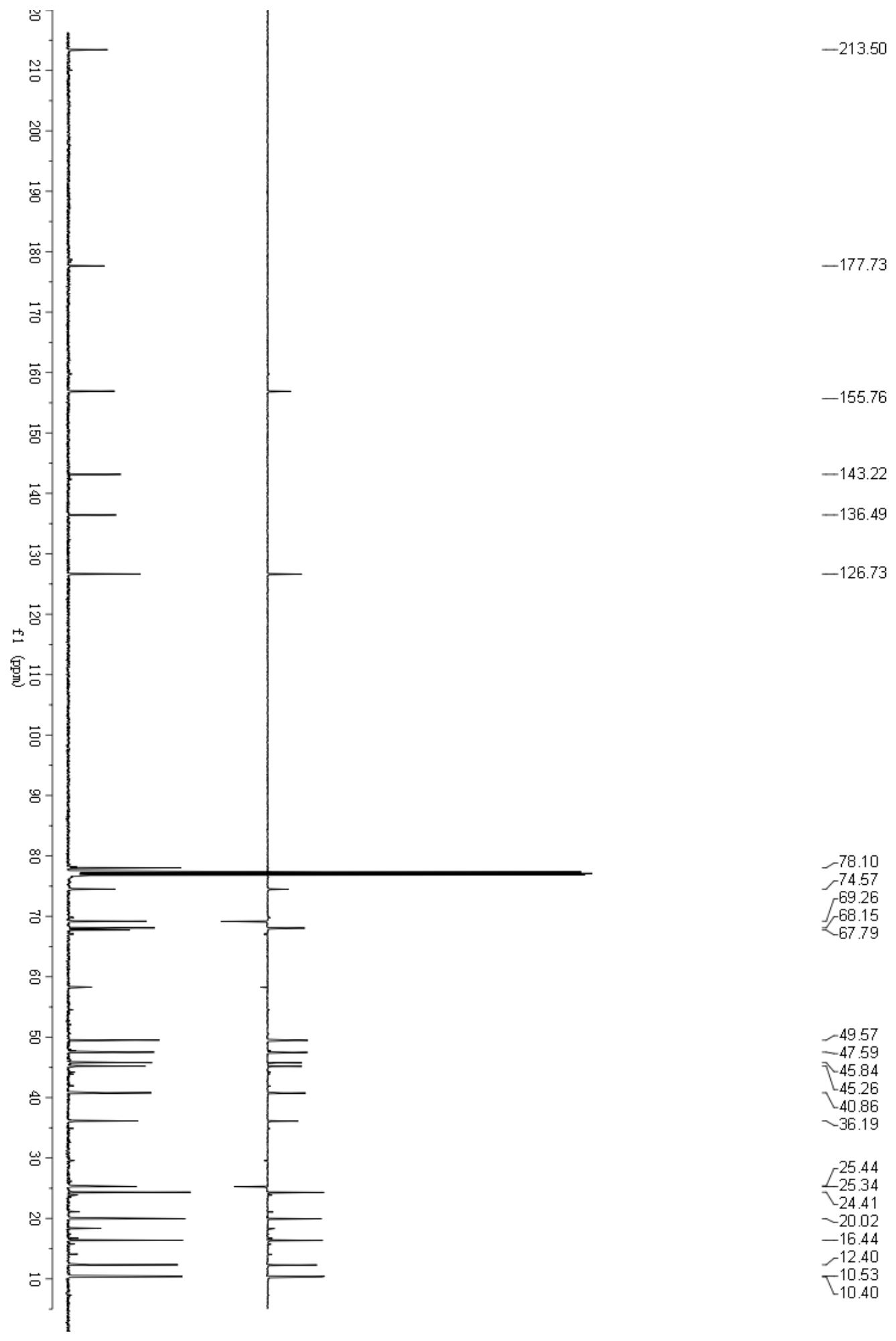

-78.10
-74.57

69.26

$-68.15$

6779

$-49.57$

$-45.84$

-45.26
40.86

-40.86
-36.19

25.44

$-25.34$

$-20.02$

$-16.44$

$-12.40$

$\tau_{10.40}$ 
Figure S66. HSQC spectrum of compound 7 in $\mathrm{CDCl}_{3}$.

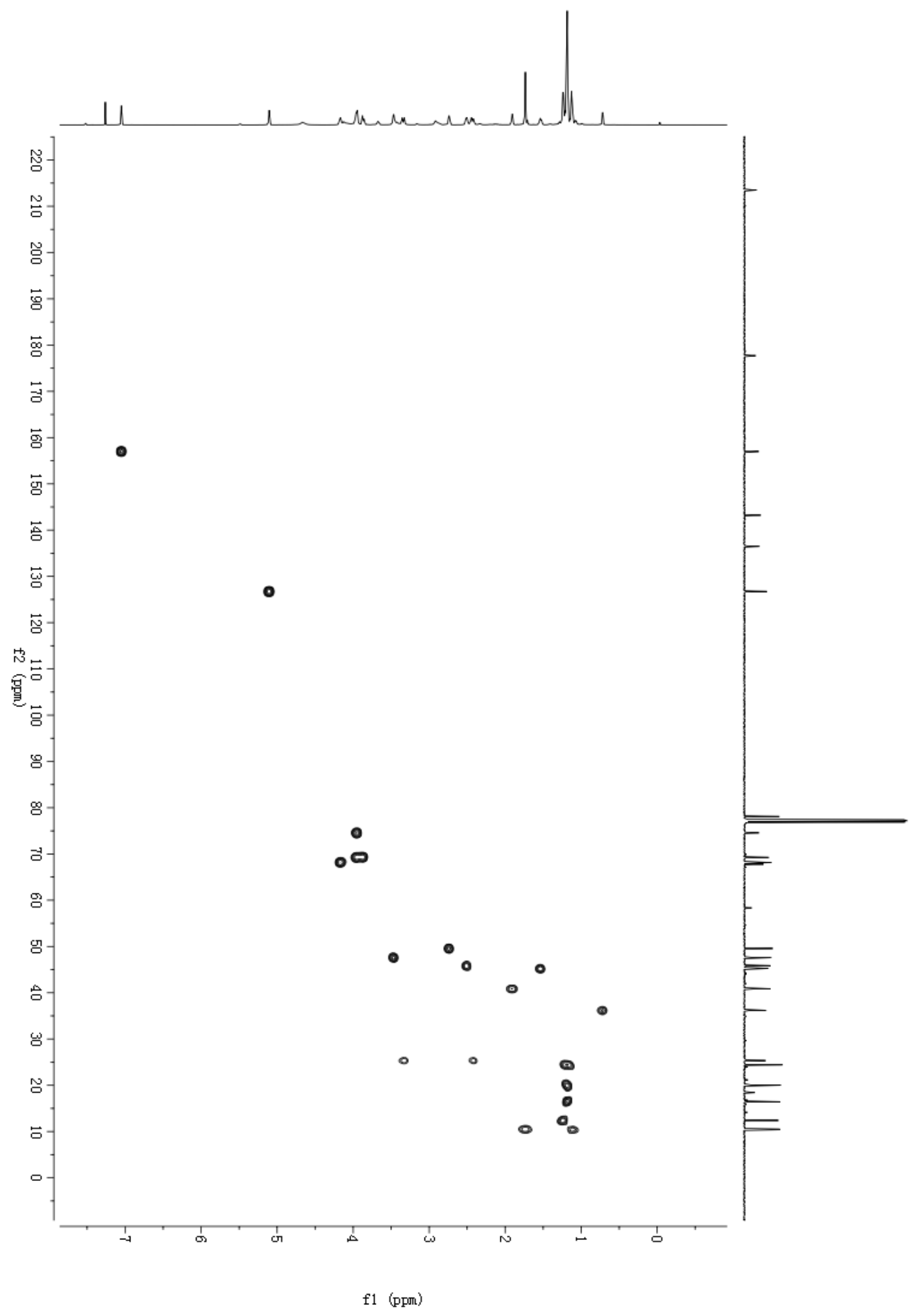


Figure S67. ${ }^{1} \mathrm{H}-{ }^{1} \mathrm{H}$ COSY spectrum of compound 7 in $\mathrm{CDCl}_{3}$.

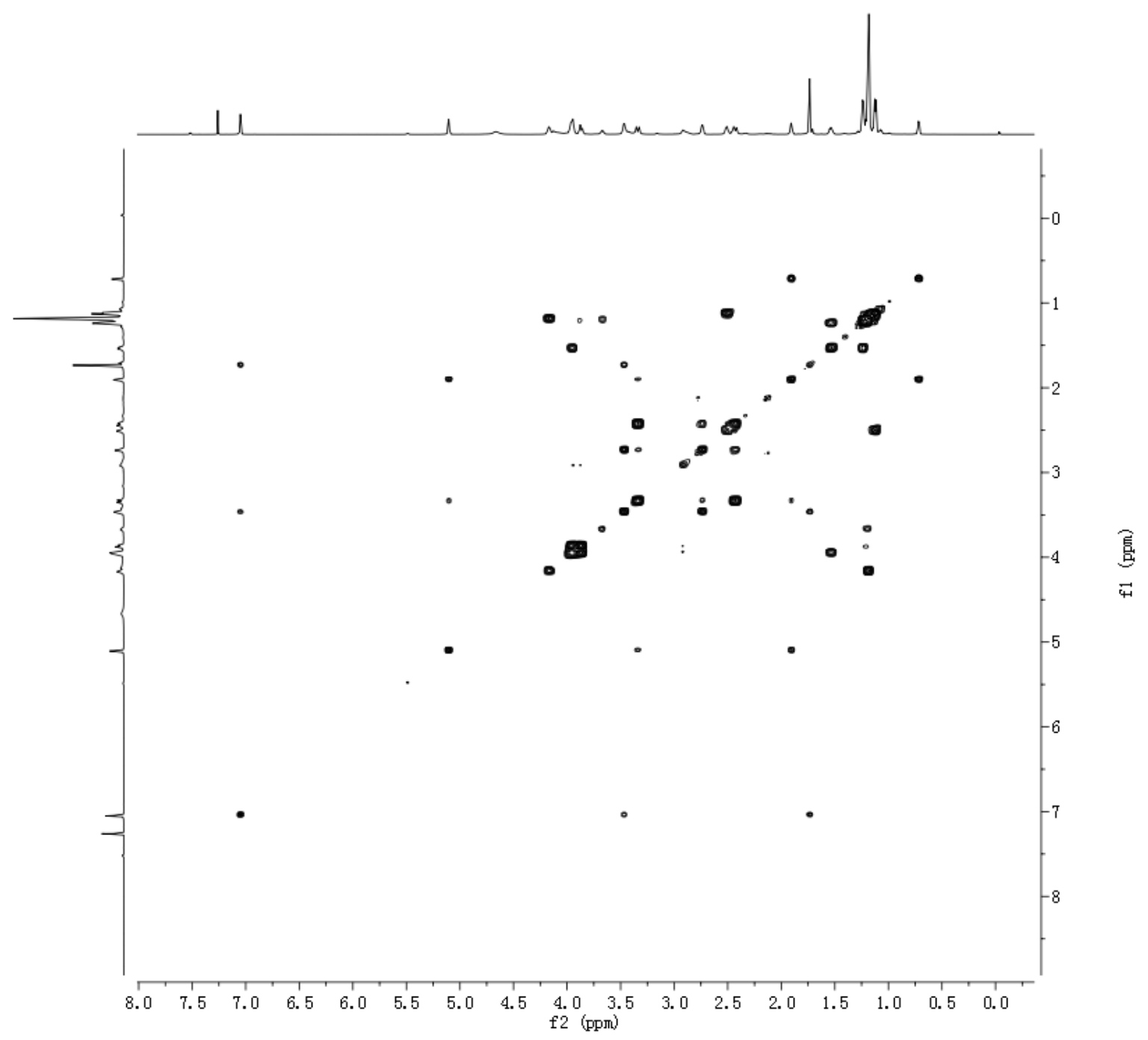


Figure S68. $\mathrm{HMBC}$ spectrum of compound 7 in $\mathrm{CDCl}_{3}$.

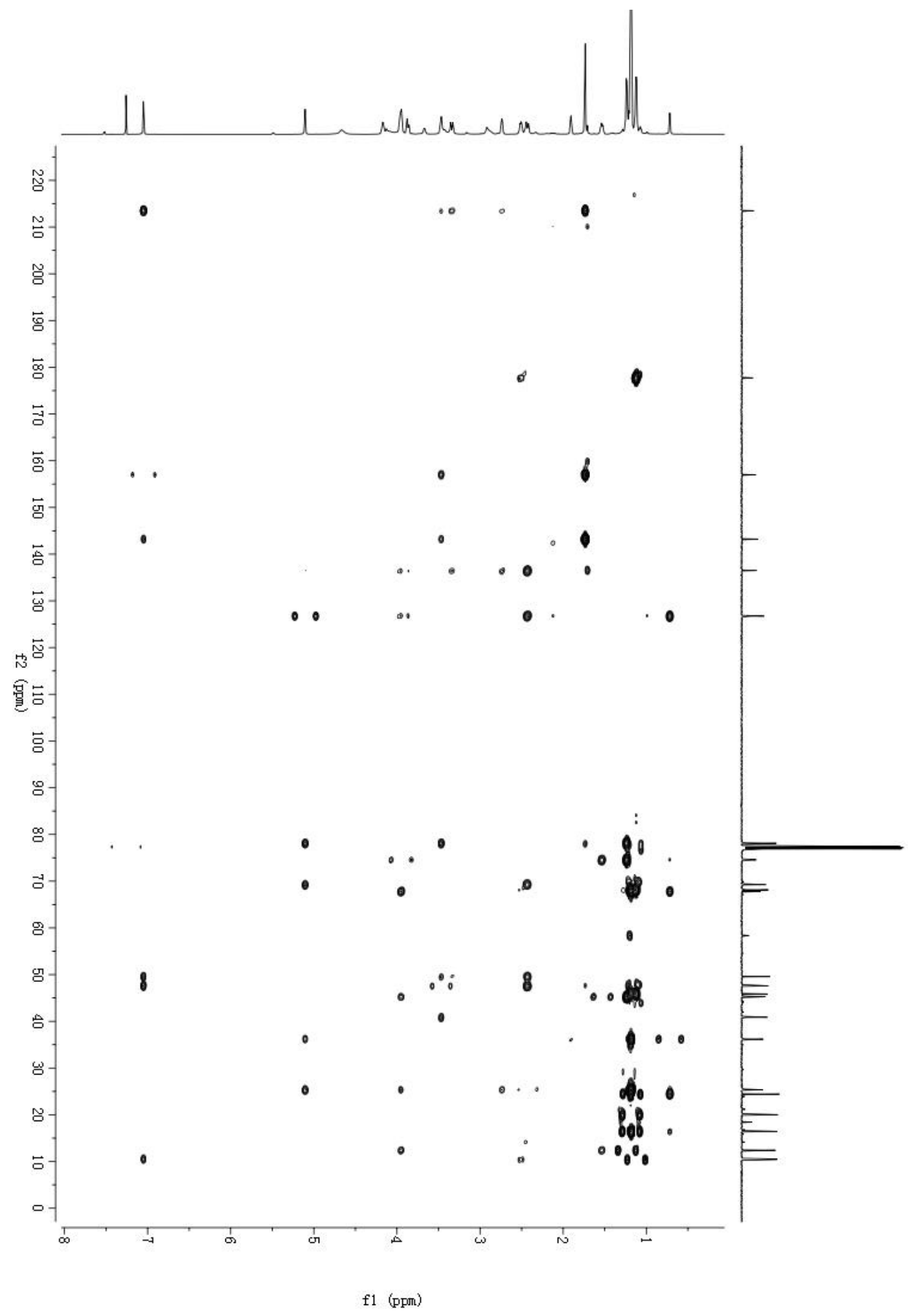


Figure S69. NOESY spectrum of compound 7 in $\mathrm{CDCl}_{3}$.

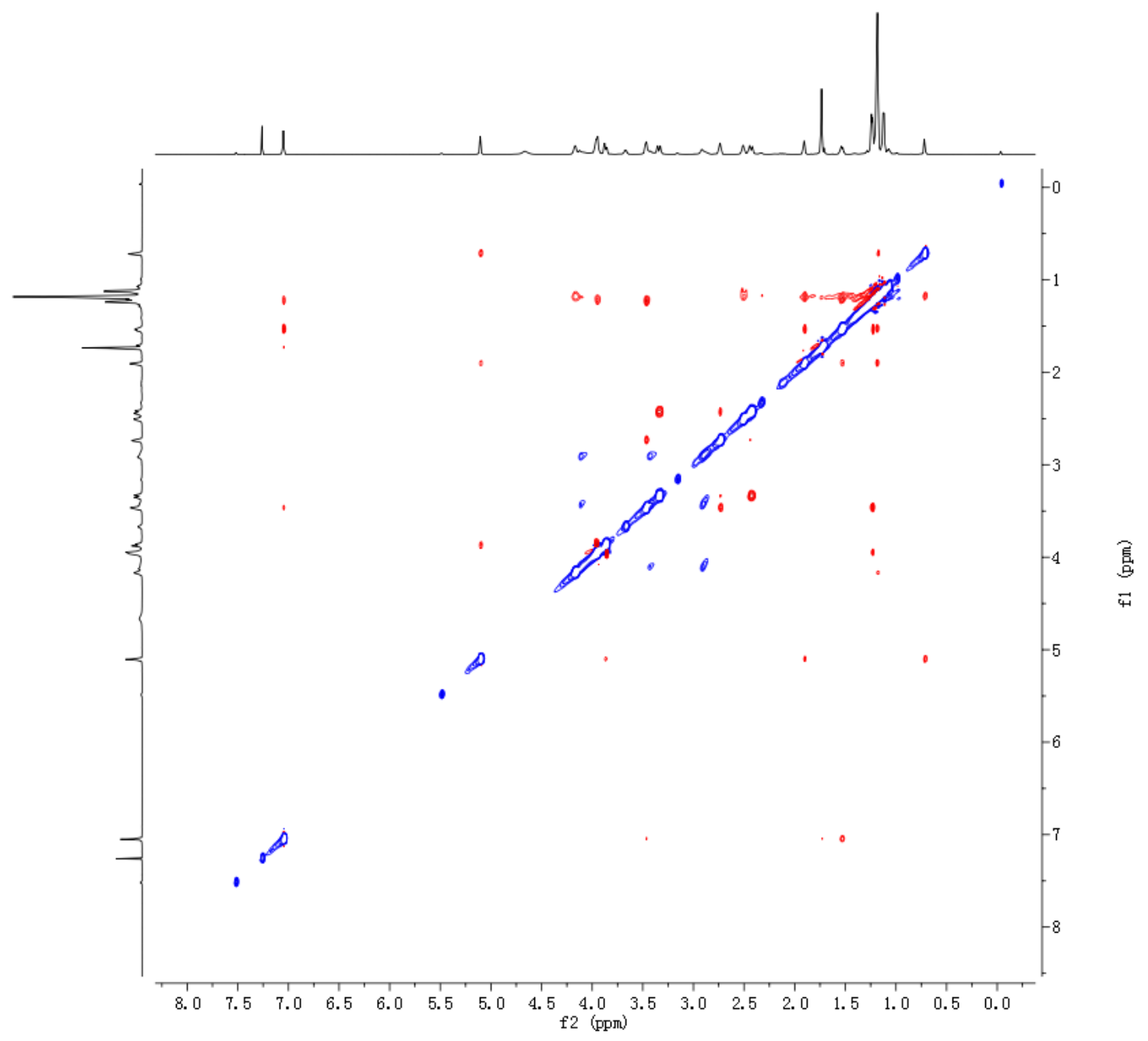


Figure S70. (+)-ESIMS spectrum of compound 7.

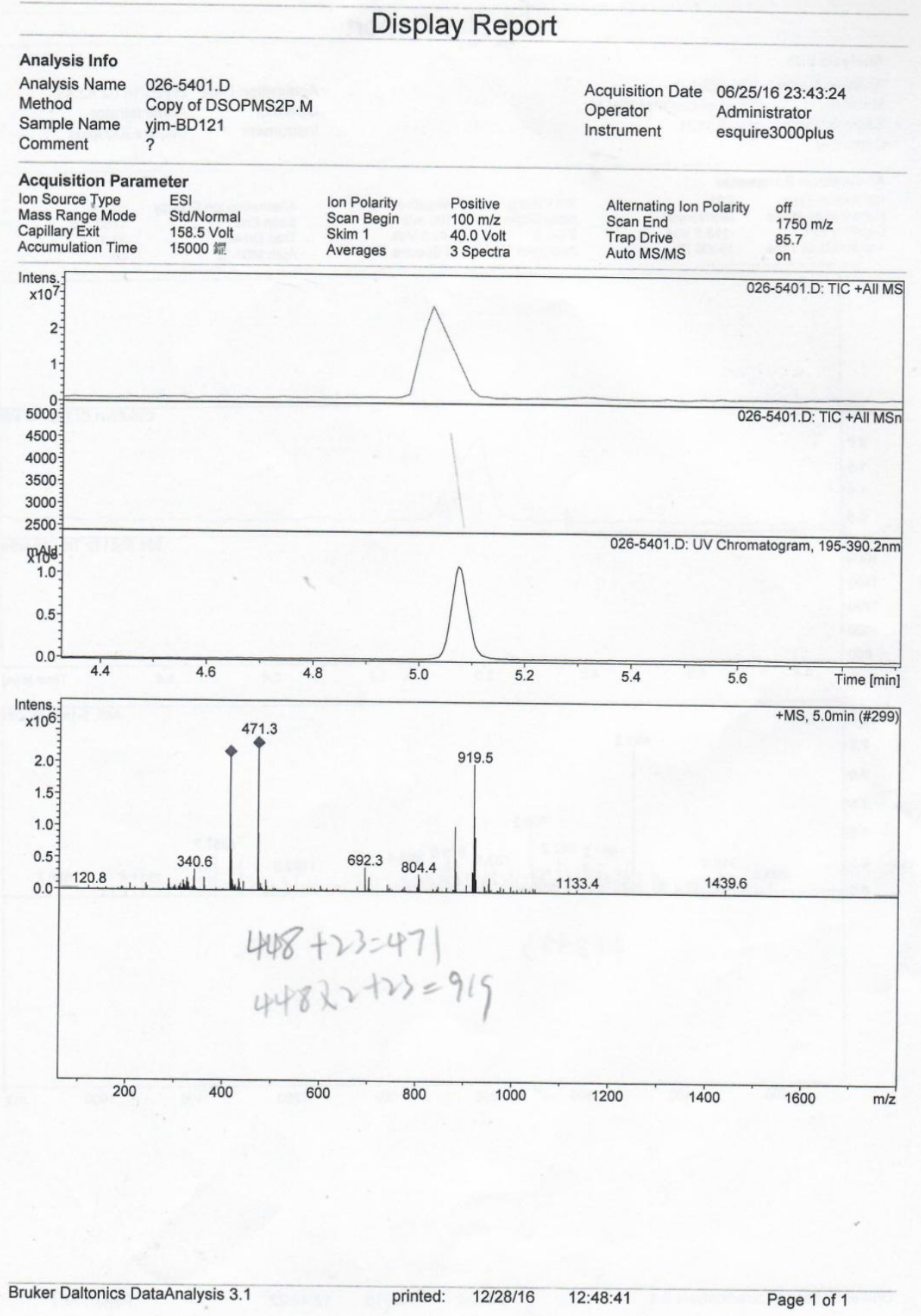


Figure S71. (-)-ESIMS spectrum of compound 7.

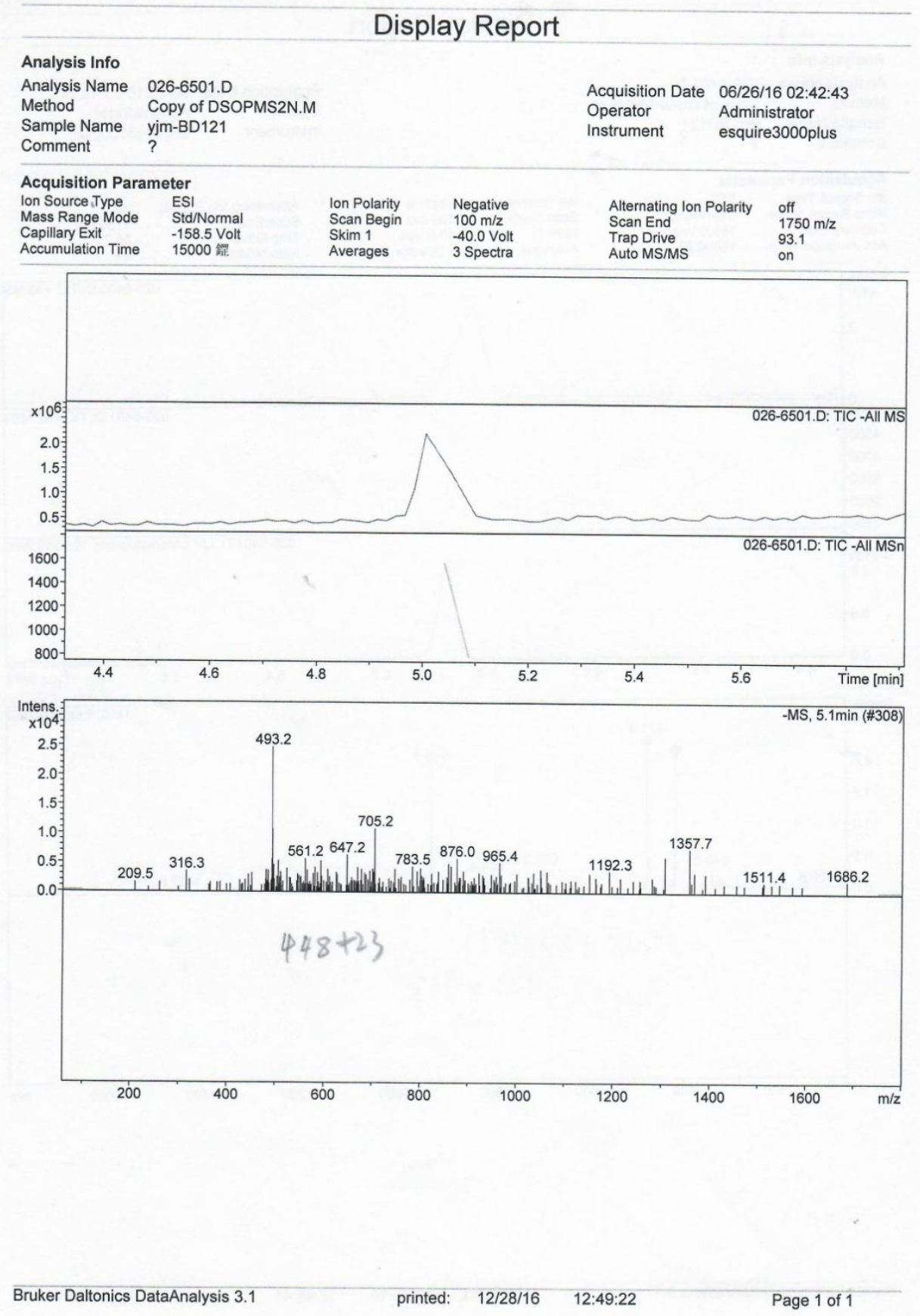


Figure S72. (+)-HRESIMS spectrum of compound 7.

Elemental Composition Report

Page 1

Single Mass Analysis

Tolerance $=3.0$ PPM / DBE: $\min =-1.5, \max =50.0$

Element prediction: Off

Number of isotope peaks used for $\mathrm{i}-\mathrm{FIT}=3$

Monoisotopic Mass, Even Electron lons

202 formula(e) evaluated with 1 results within limits (up to 50 best isotopic matches for each mass)

202 formula(e) evaluated with 1 results with

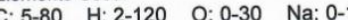

LCT PXE KE324

03-Jul-2017

$11: 32: 35$
$B D 12116(0.318) \mathrm{Cm}(16)$

1: TOF MS ES+

$3.29 \mathrm{e}+003$

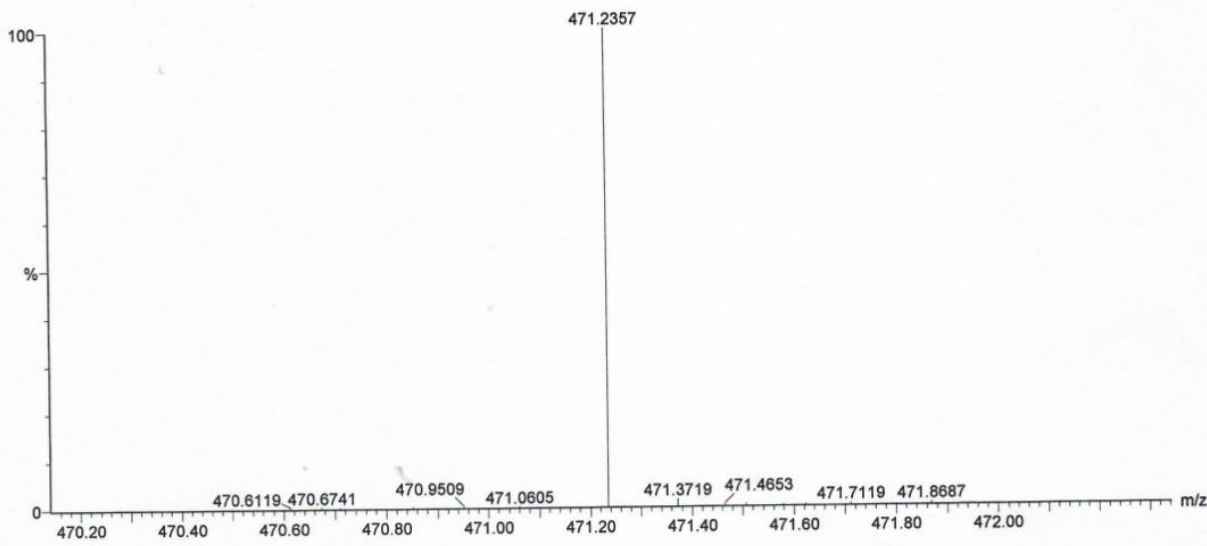

Minimum:

aximum:

$\begin{array}{llll}5.0 & 3.0 & -1.5 \\ & & 50.0\end{array}$

Mass Calc. Mass mDa PPM DBE

$\begin{array}{lllll}471.2357 & 471.2359 & -0.2 & -0.4 & 7 .\end{array}$

i-FIT i-FIT (Norm) Formula

$\begin{array}{llll}-0.2 & -0.4 & 7.5 & 61.2\end{array}$

0.0

C25 H36 $07 \quad \mathrm{Na}$ 
Figure S73. IR spectrum of compound 7.

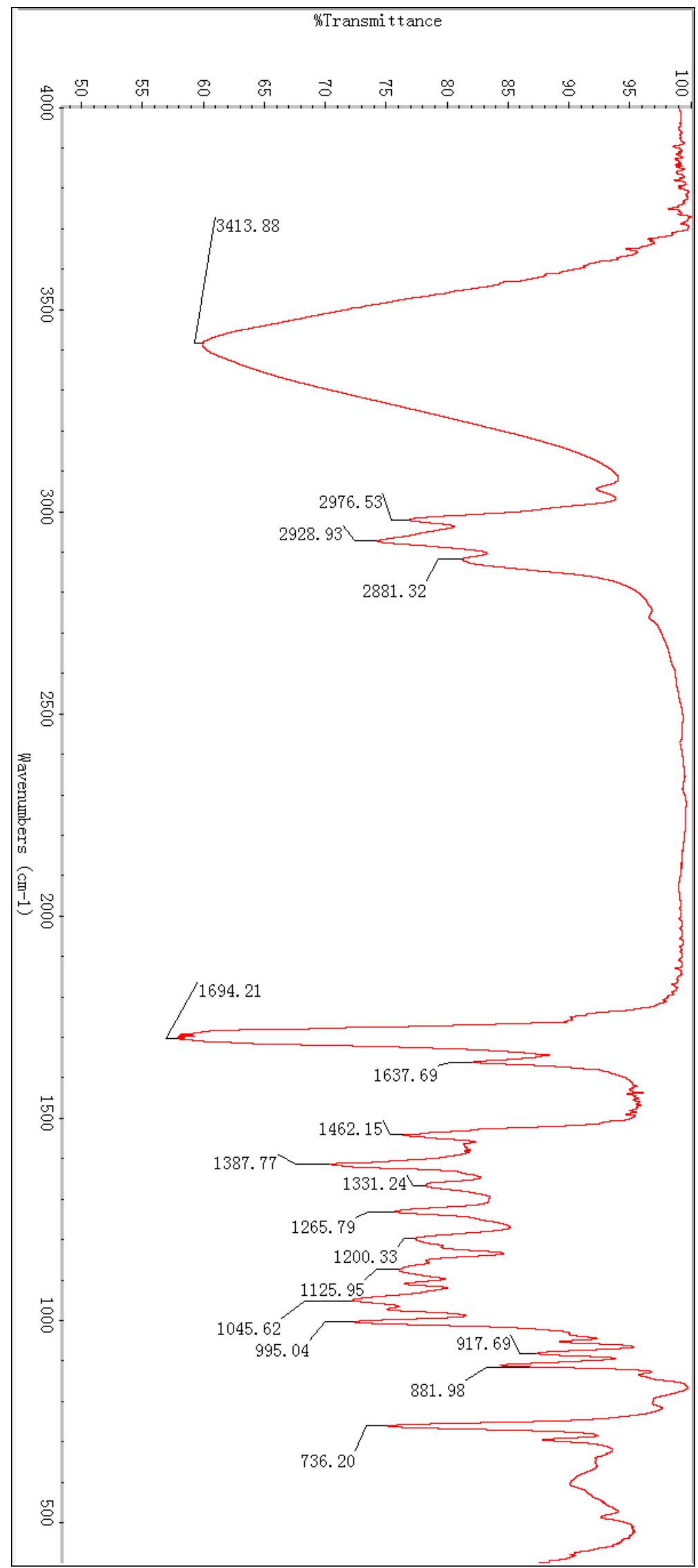


Figure S74. ${ }^{1} \mathrm{H}$ NMR spectrum of compound 8 in $\mathrm{CDCl}_{3}$.

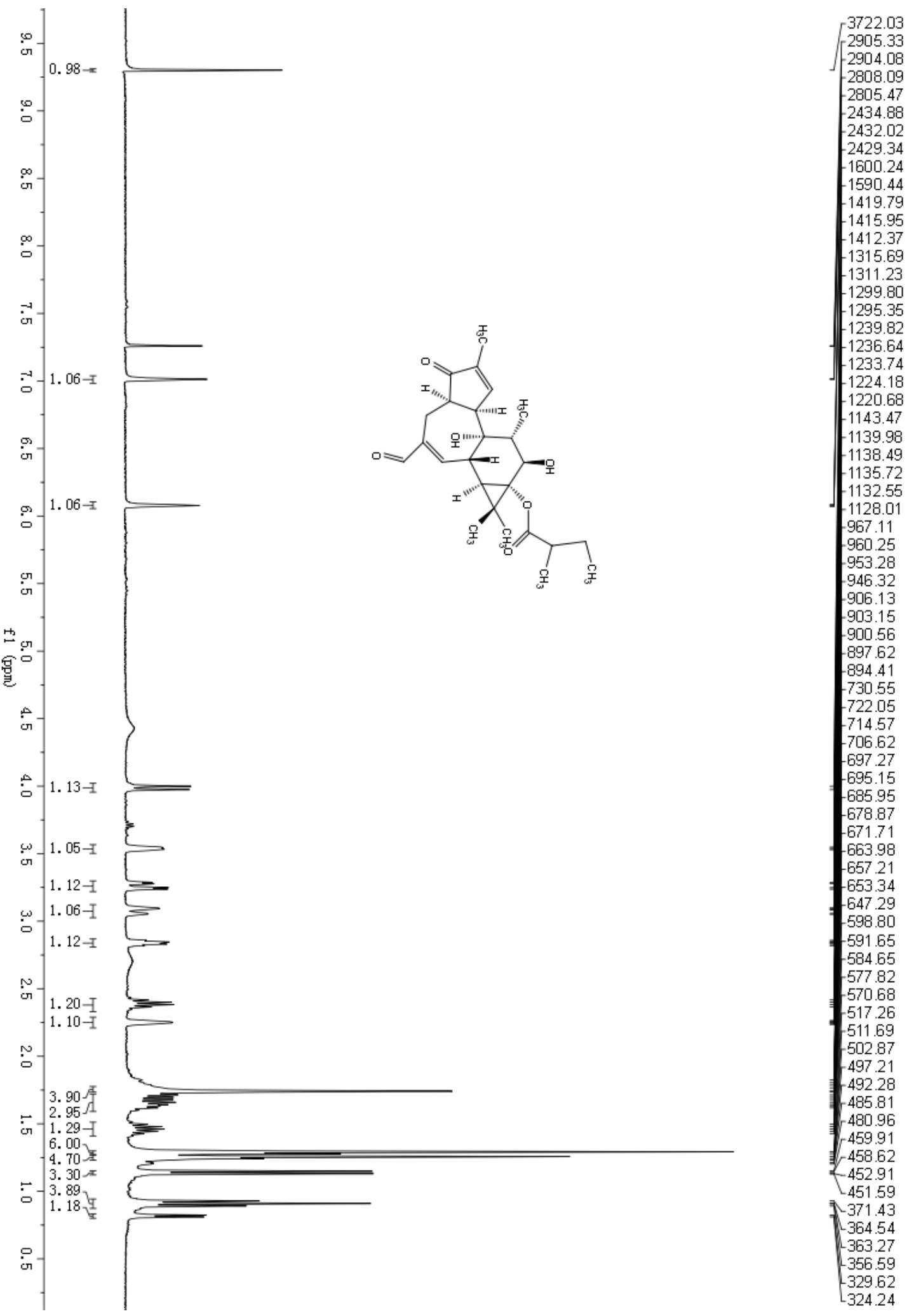


Figure S75. ${ }^{13} \mathrm{C}$ NMR spectrum of compound 8 in $\mathrm{CDCl}_{3}$.
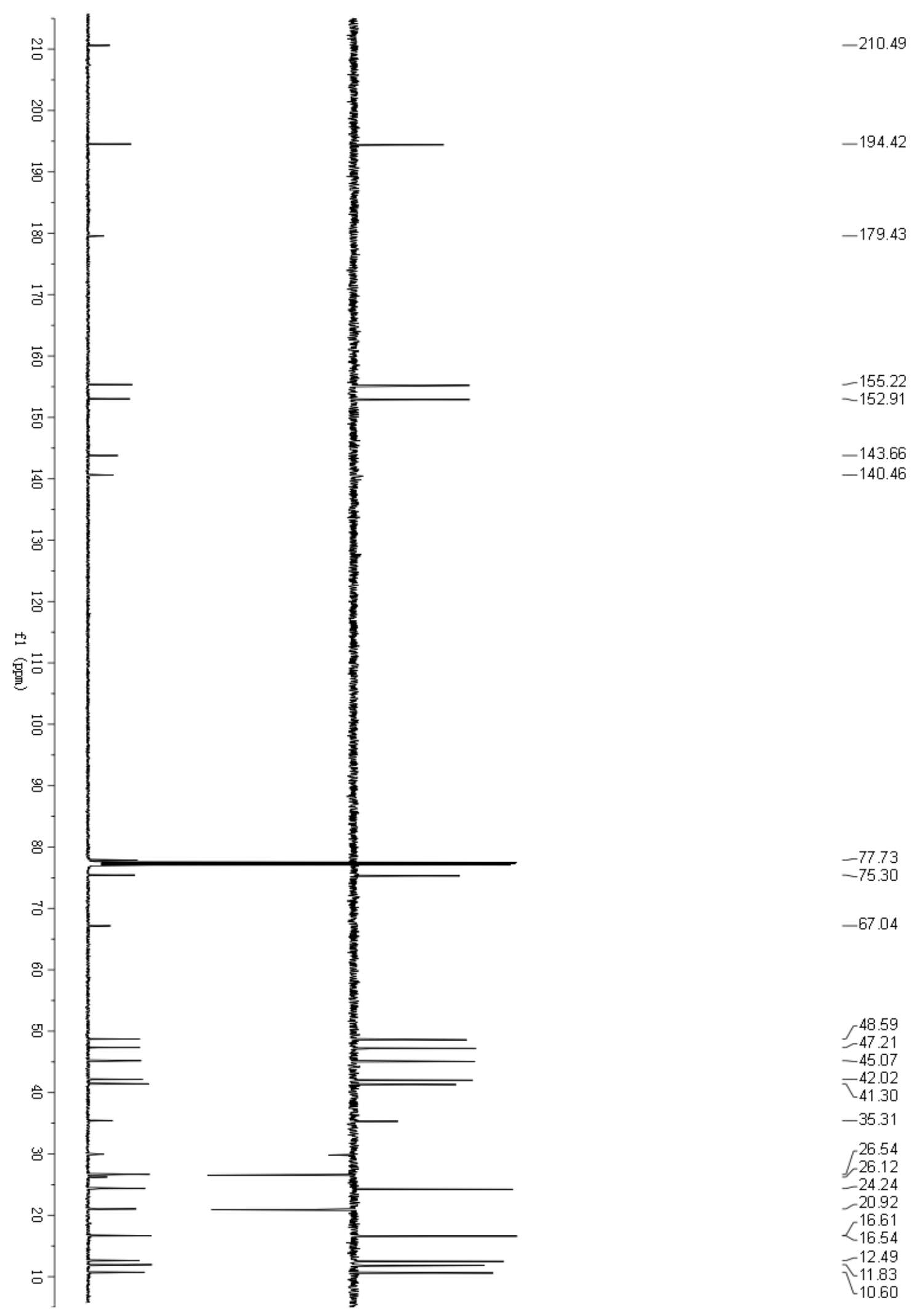

-77.73
-75.30

$-67.04$

$\tau_{-47.21}^{48.59}$

$-45.07$

$-42.02$

$-41.30$

$-35.31$

26.54
26.12

$-24.24$

$-20.92$

16.61

$\chi_{16.54}$

$-12.49$

$\checkmark 10.60$ 
Figure S76. HSQC spectrum of compound 8 in $\mathrm{CDCl}_{3}$.

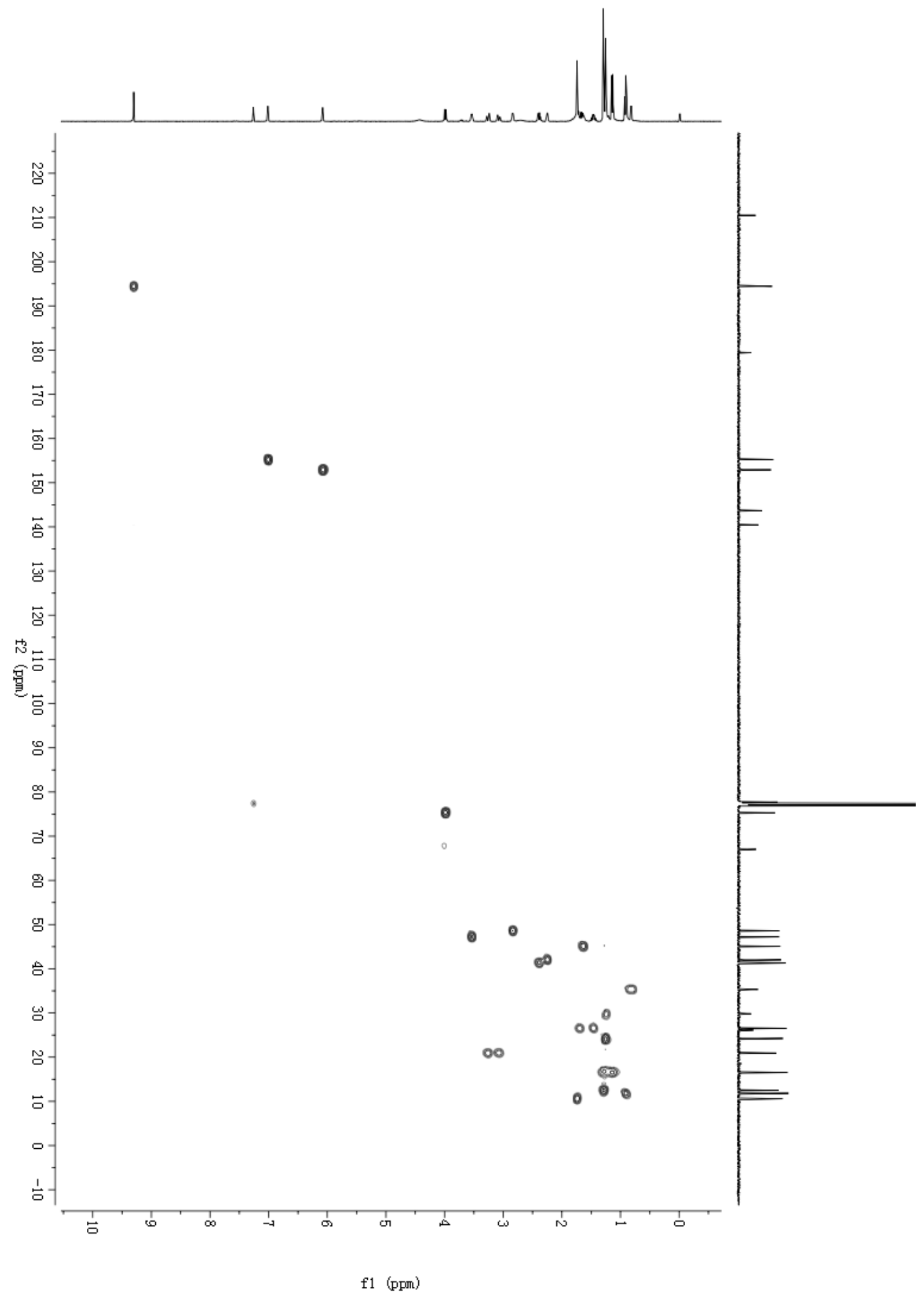


Figure S77. ${ }^{1} \mathrm{H}-{ }^{1} \mathrm{H}$ COSY spectrum of compound 8 in $\mathrm{CDCl}_{3}$.

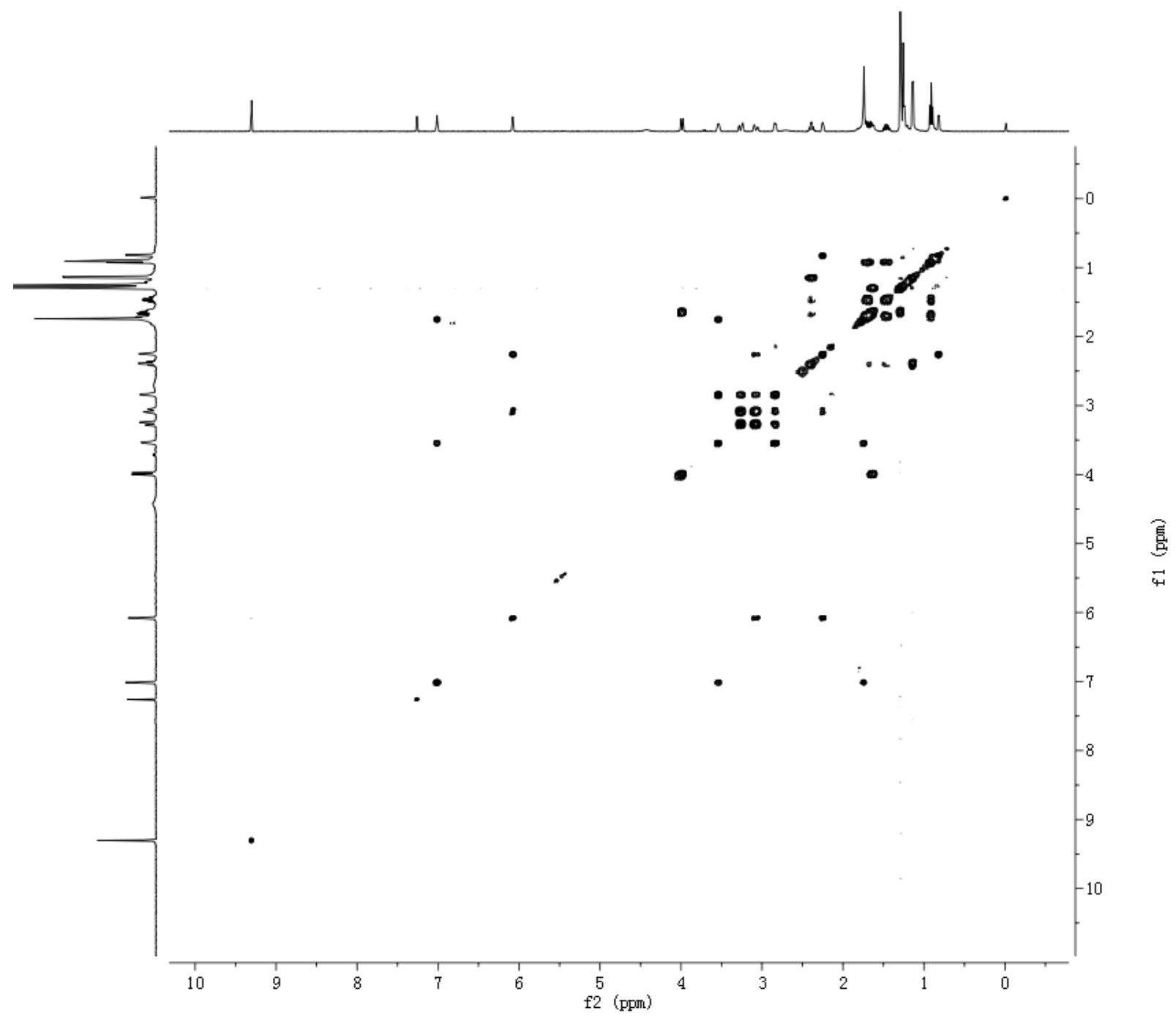


Figure S78. $\mathrm{HMBC}$ spectrum of compound $\mathbf{8}$ in $\mathrm{CDCl}_{3}$.

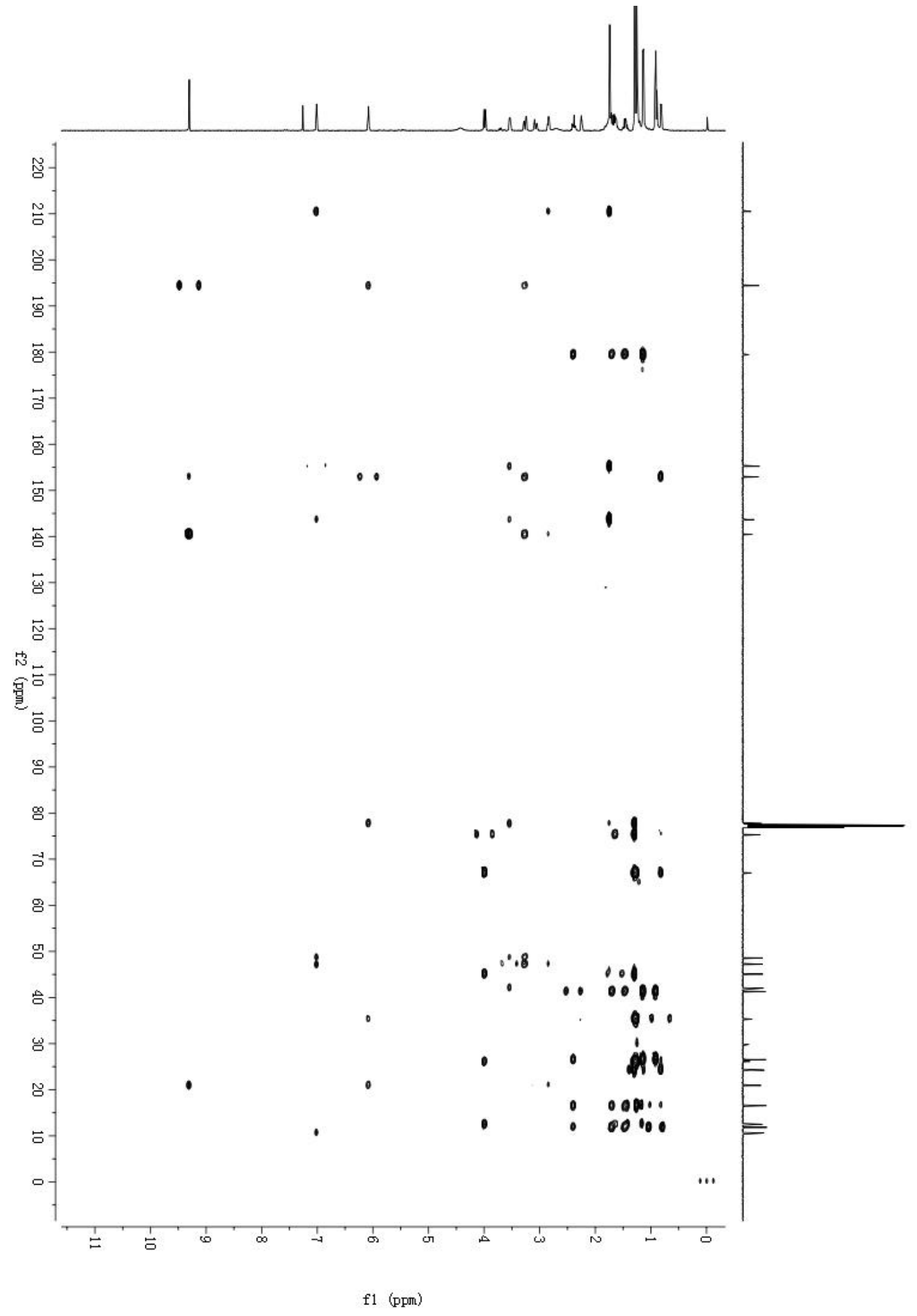


Figure S79. NOESY spectrum of compound $\mathbf{8}$ in $\mathrm{CDCl}_{3}$.

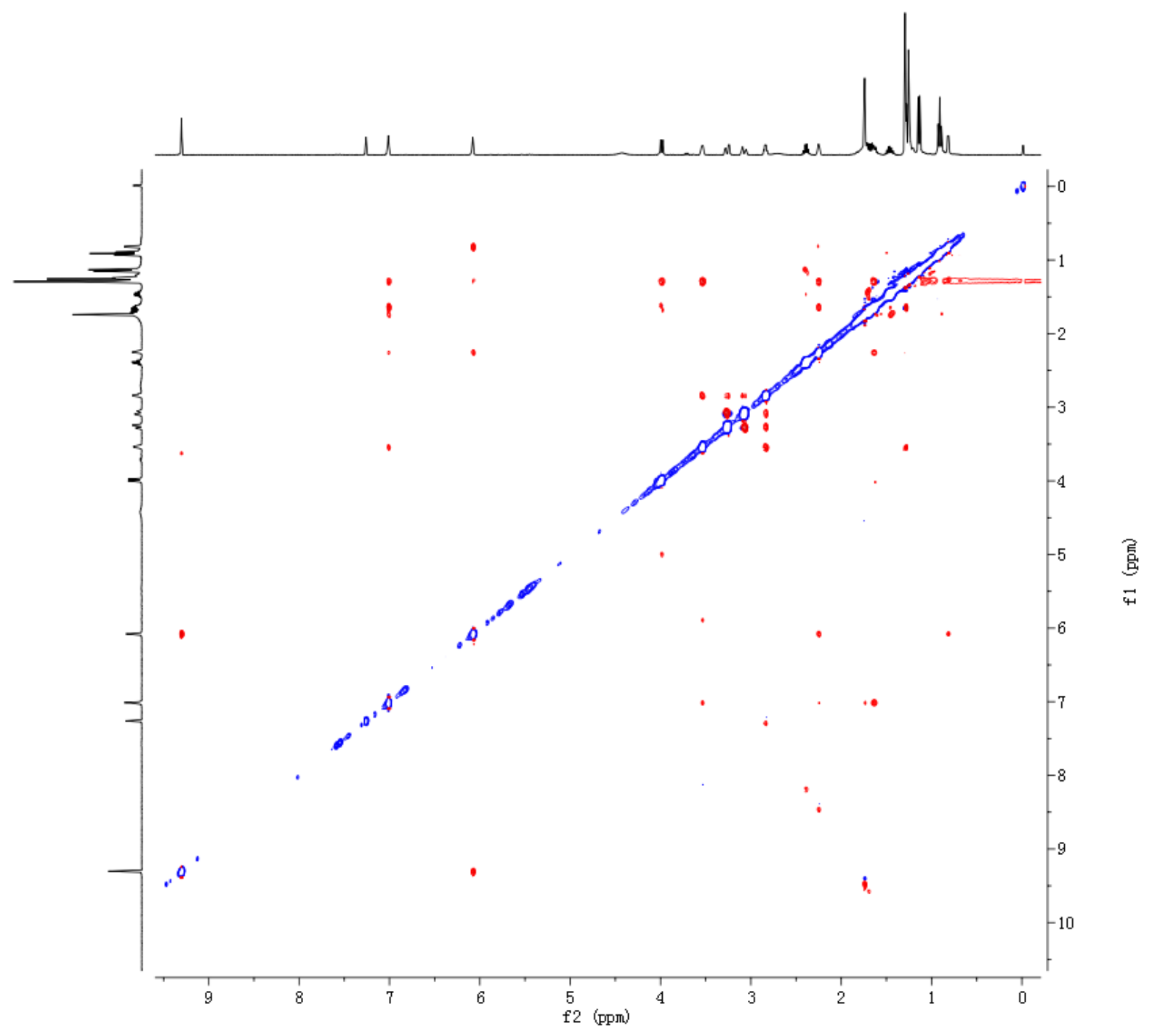


Figure S80. (+)-ESIMS spectrum of compound 8.

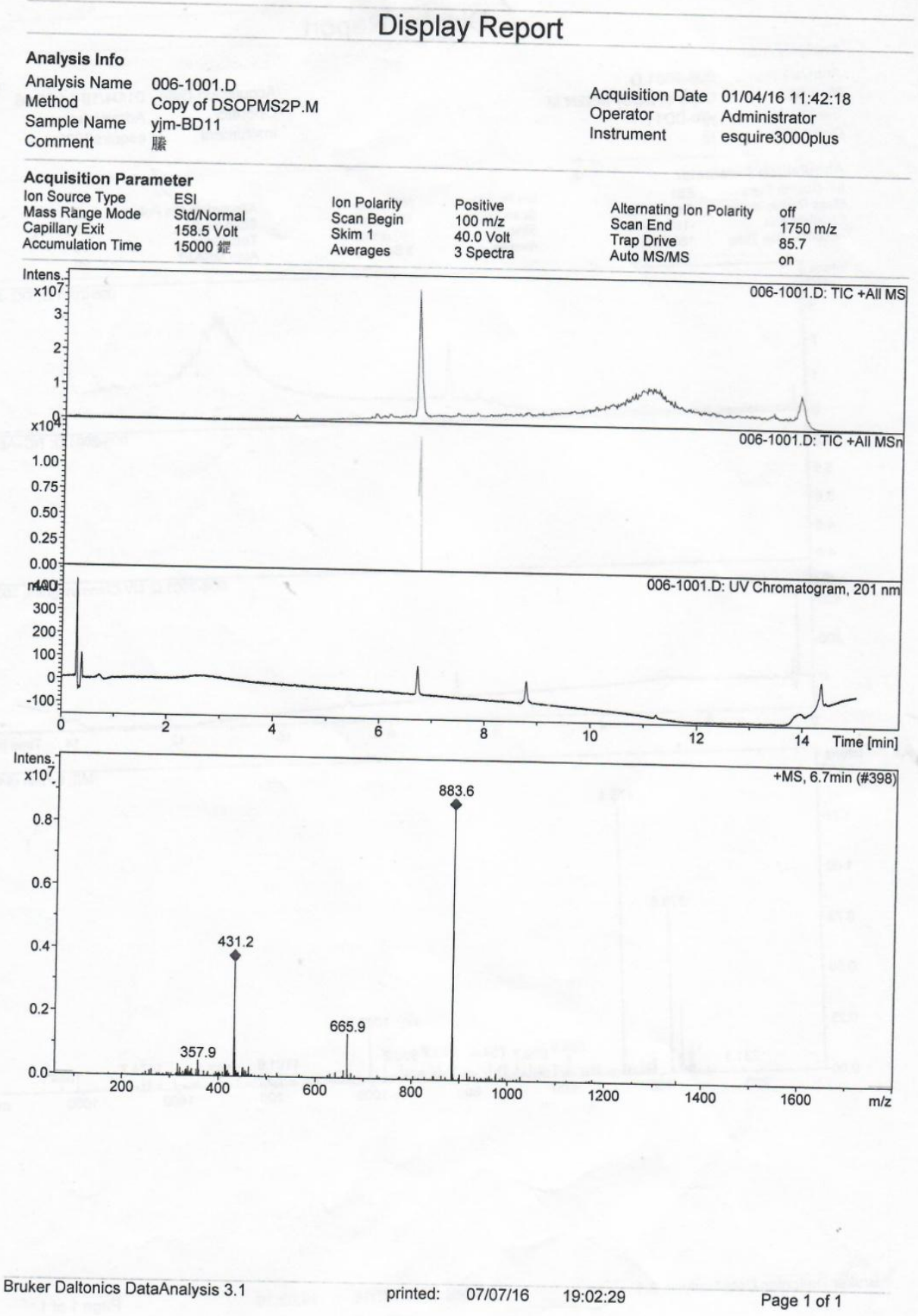


Figure S81. (-)-ESIMS spectrum of compound 8.

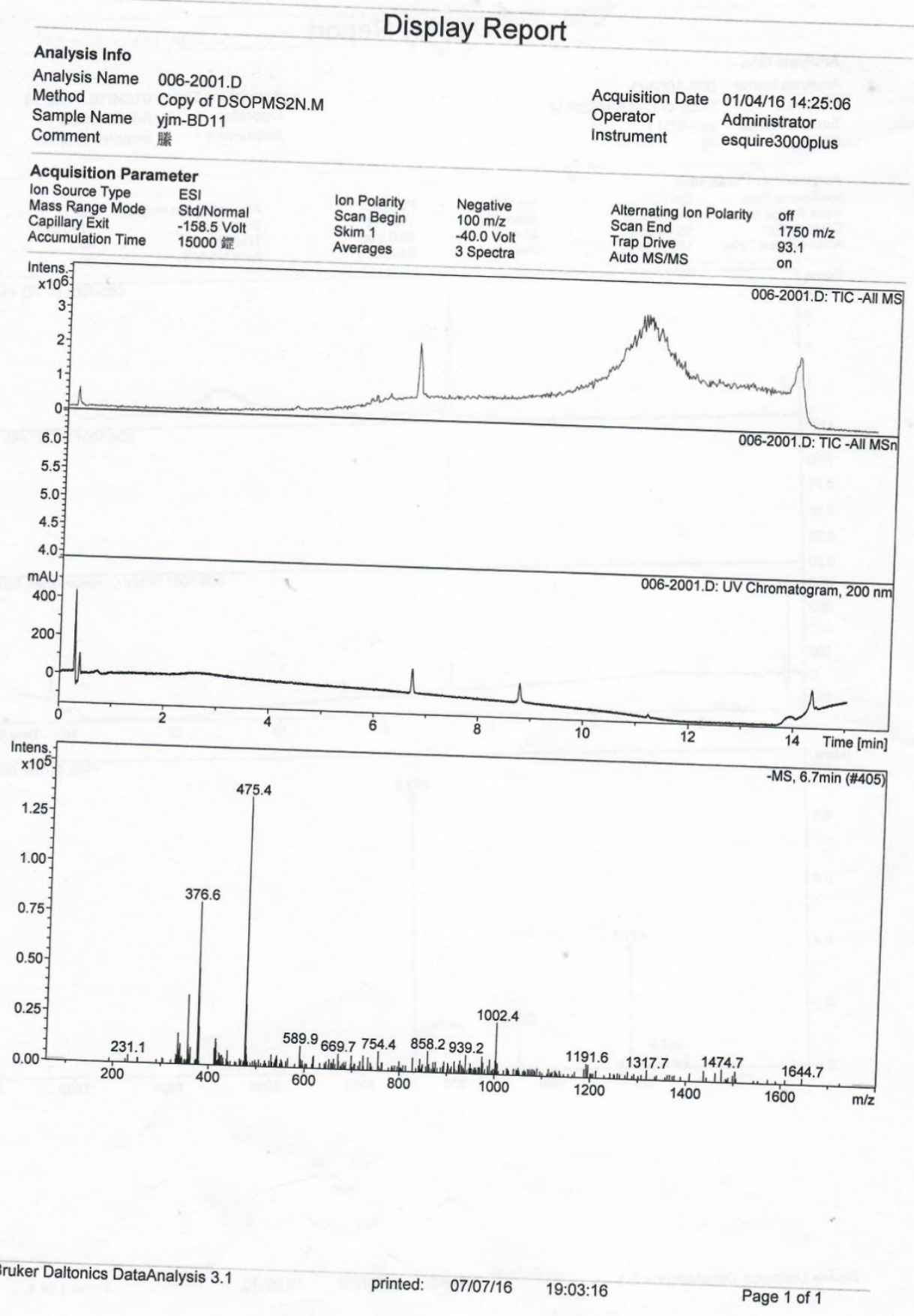


Figure S82. (+)-HRESIMS spectrum of compound 8.

Single Mass Analysis

Tolerance $=1.0$ PPM I DBE: $\min =-1.5, \max =50.0$

Element prediction: Off

Number of isotope peaks used for $\mathrm{i}-\mathrm{FIT}=3$

Monoisotopic Mass, Even Electron Ions

502 formula(e) evaluated with 1 results within limits (up to 50 best isotopic matches for each mass)

Elements Used:

$\begin{array}{lll}\text { C: } 5-80 & \text { H: } 2-120 & \text { O: } 0-30 \\ \text { Na: } 0-1\end{array}$

LCT PXE KE324

29-Jun-2017

BD11 $84(1.818) \mathrm{Cm}(82: 84)$

1: TOF MS ES+

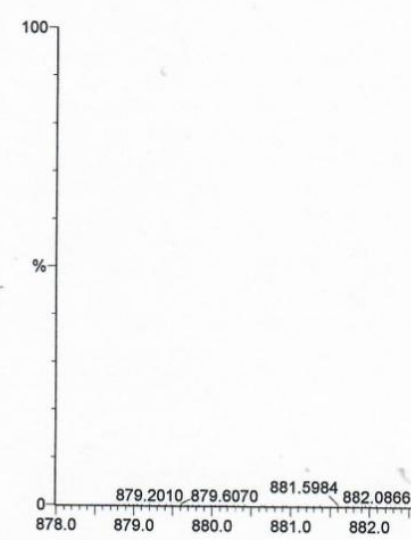

883.4613

$1.12 \mathrm{e}+004$

Minimum:

Mass

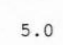

883.4613

Calc. Mass

5.0

1.0

-1.5
$.0 \quad 50.0$

122.9

i-FIT (Norm) Formula

$\begin{array}{lllll}0.0 & \mathrm{C} 50 & \mathrm{H} 68 & 012 & \mathrm{Na}\end{array}$ 
Figure S83. IR spectrum of compound 8 .

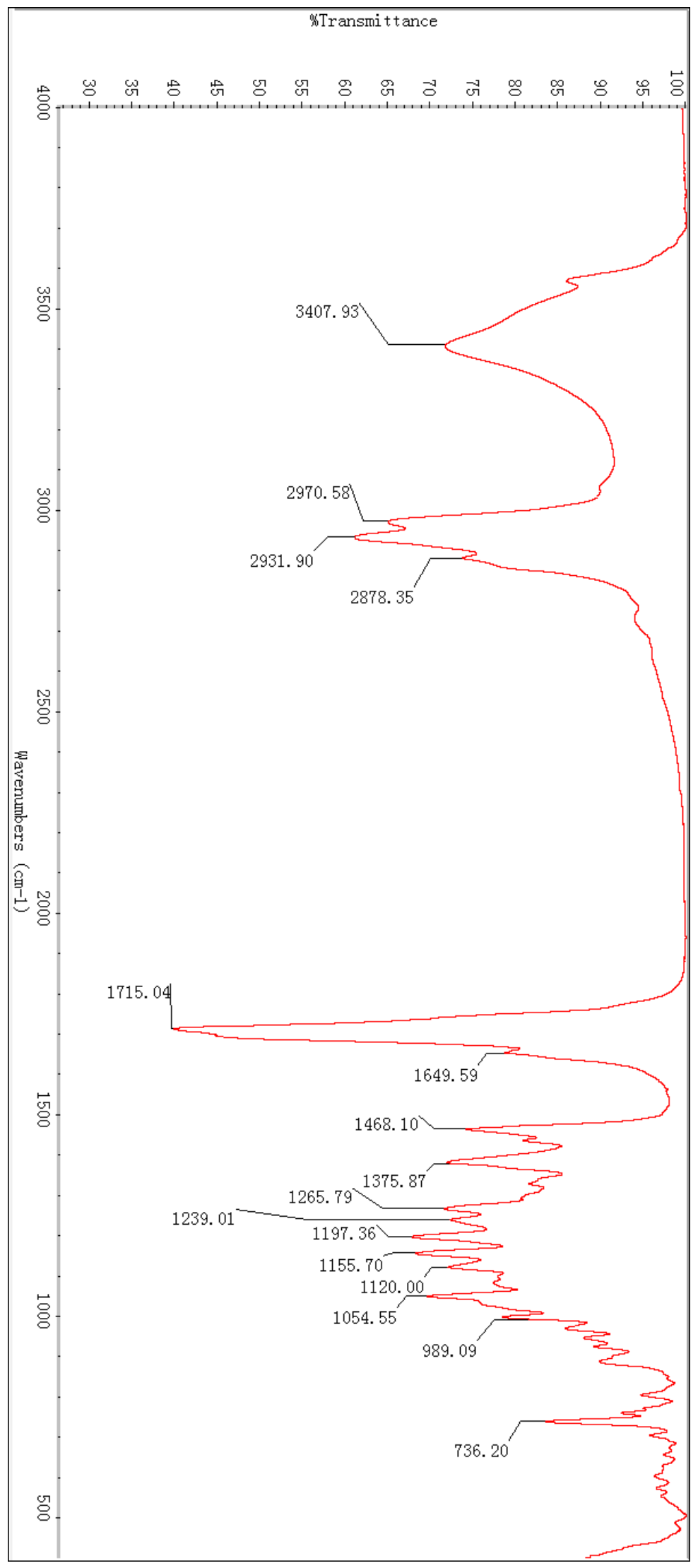


Figure S84. ${ }^{1} \mathrm{H}$ NMR spectrum of compound 9 in $\mathrm{CDCl}_{3}$.
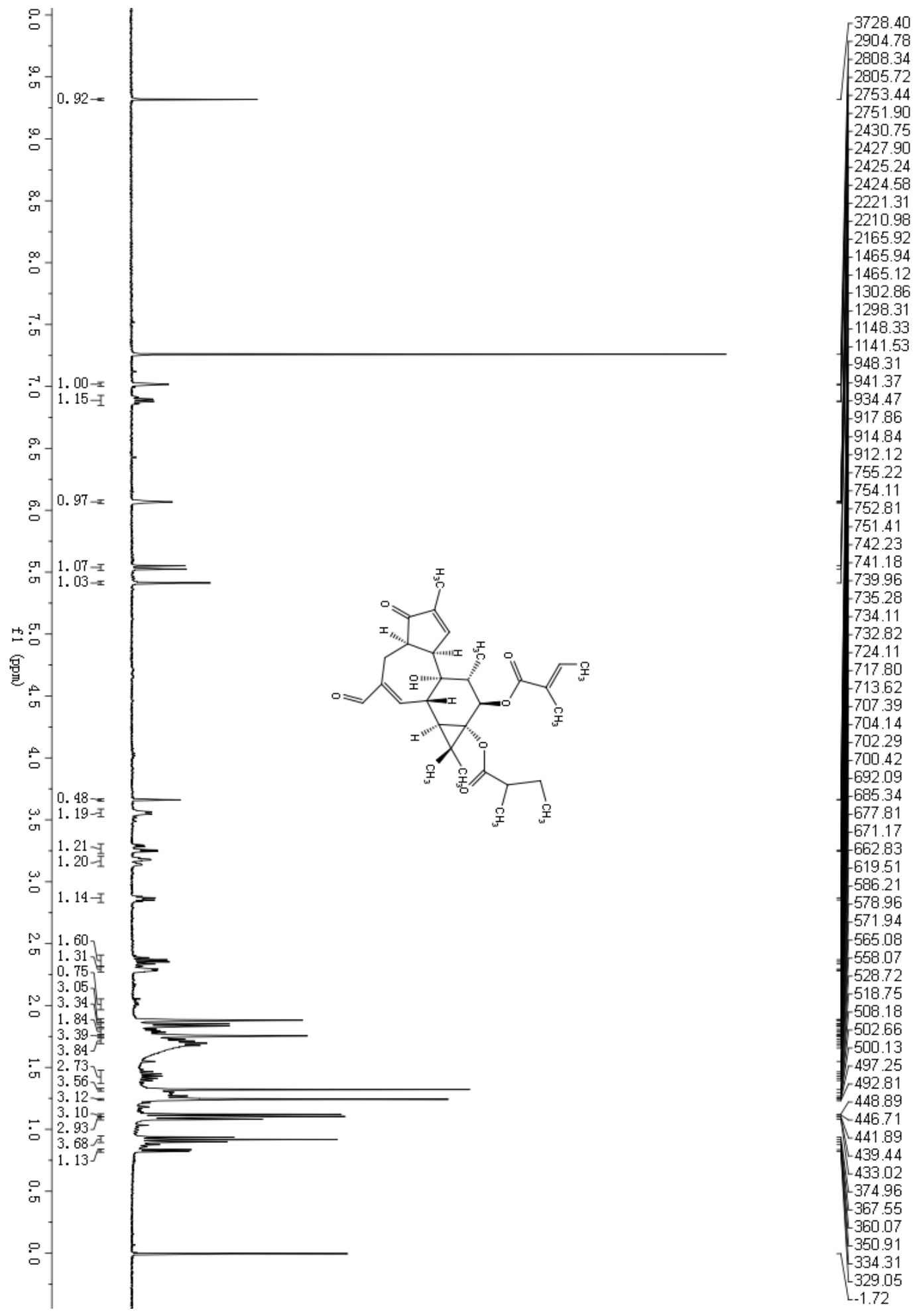


$$
\mathbb{I}
$$


Figure S86. HSQC spectrum of compound 9 in $\mathrm{CDCl}_{3}$.

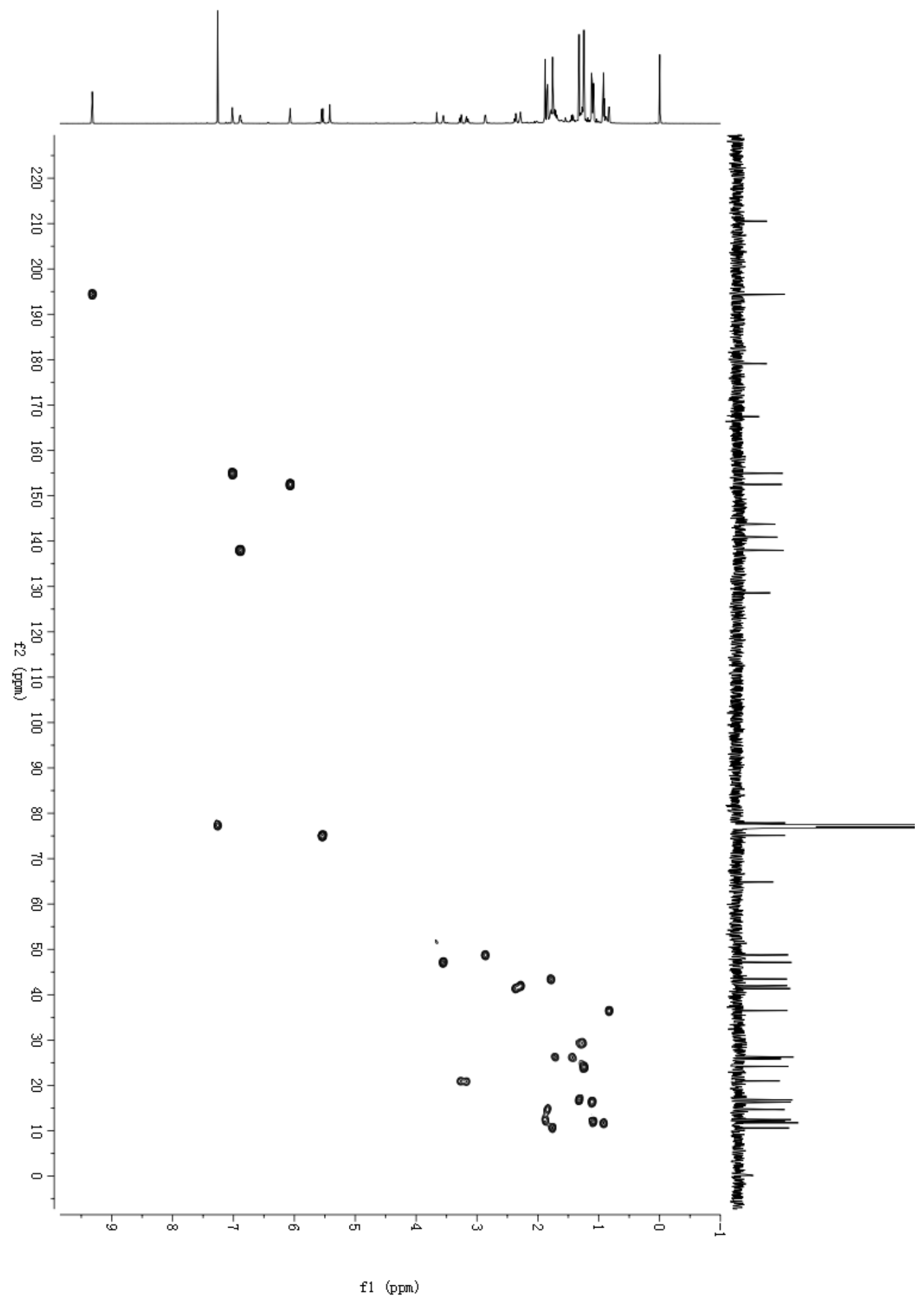

98 
Figure S87. ${ }^{1} \mathrm{H}-{ }^{1} \mathrm{H}$ COSY spectrum of compound 9 in $\mathrm{CDCl}_{3}$.

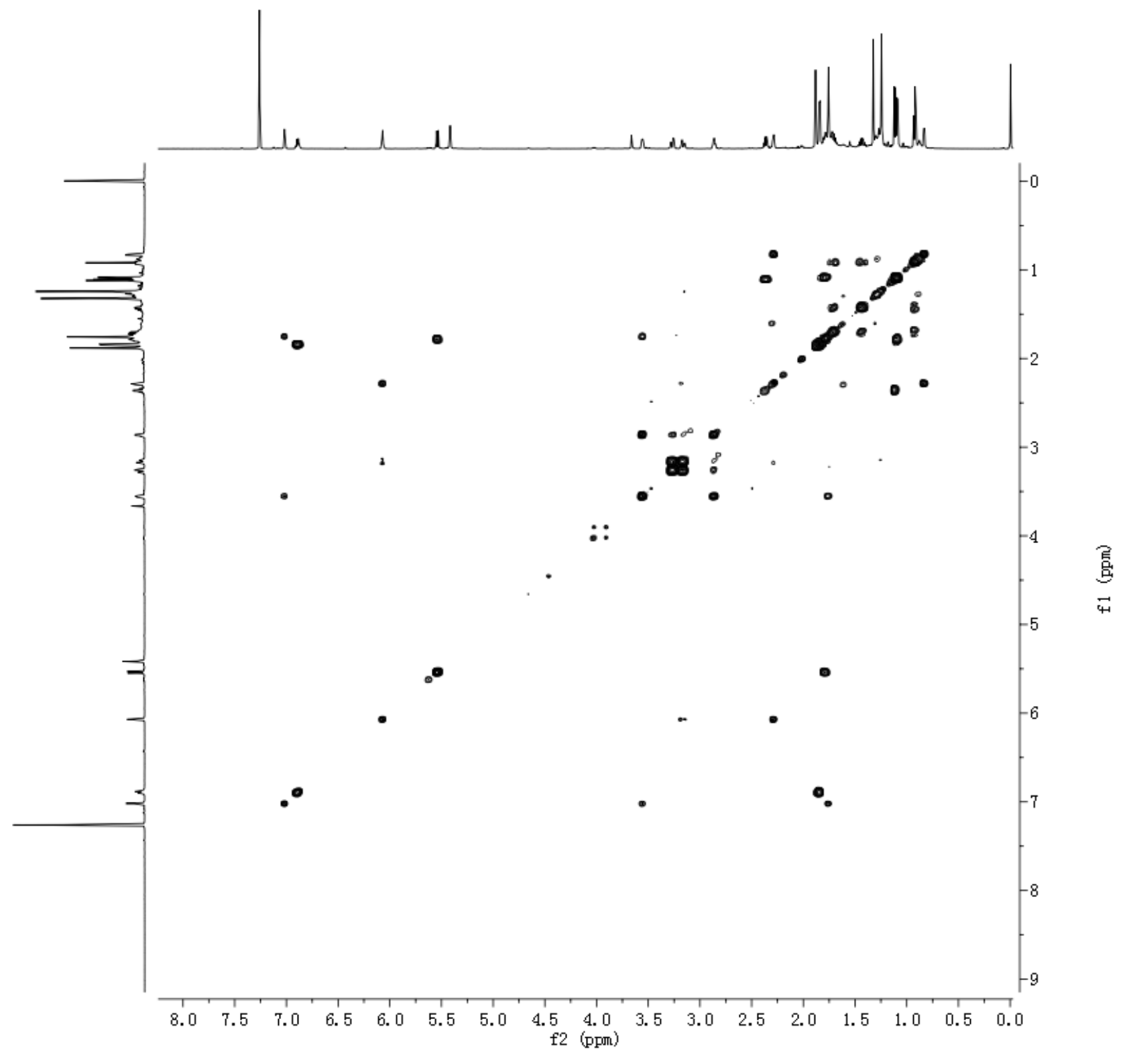


Figure S88. $\mathrm{HMBC}$ spectrum of compound 9 in $\mathrm{CDCl}_{3}$.

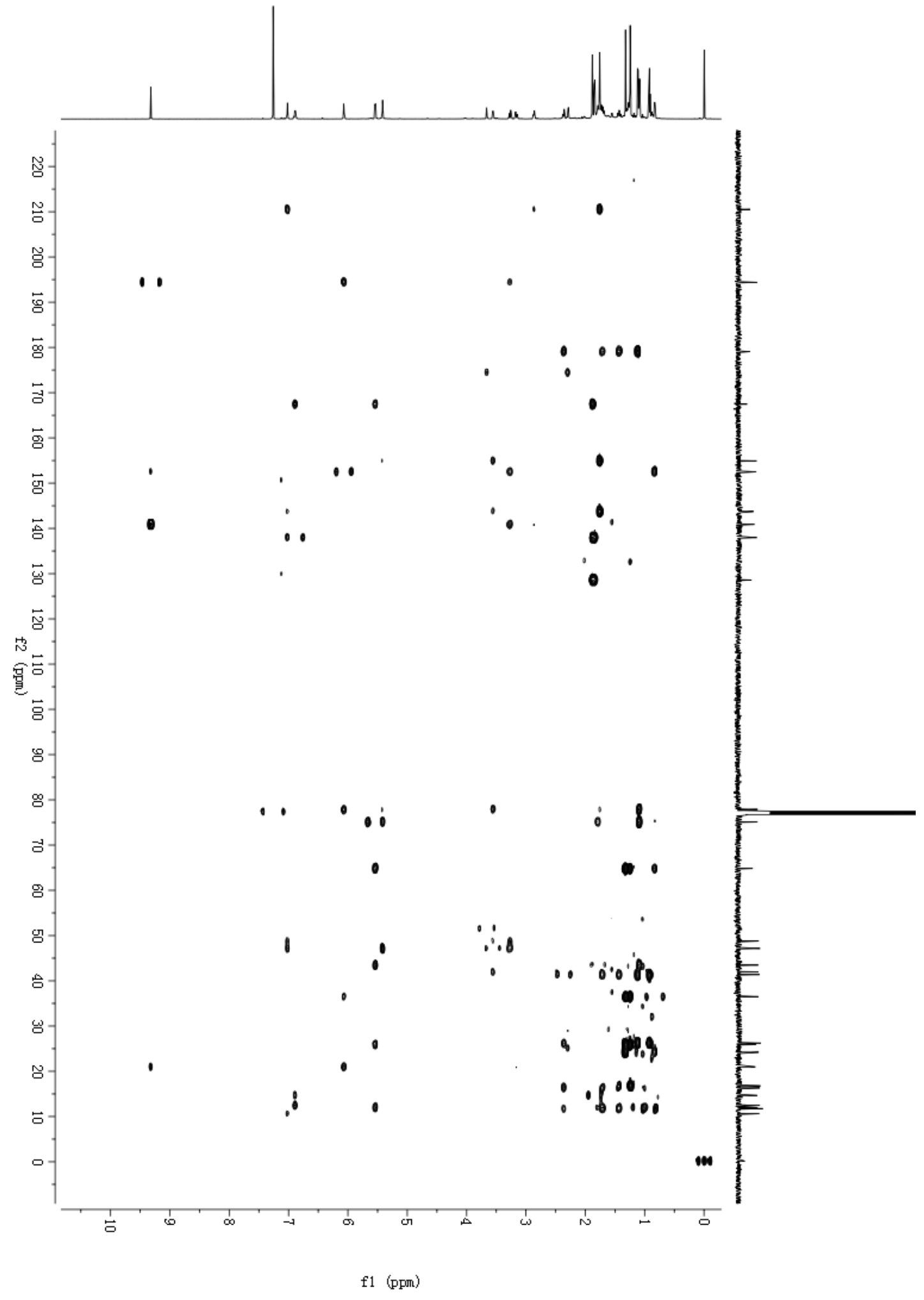


Figure S89. NOESY spectrum of compound 9 in $\mathrm{CDCl}_{3}$.

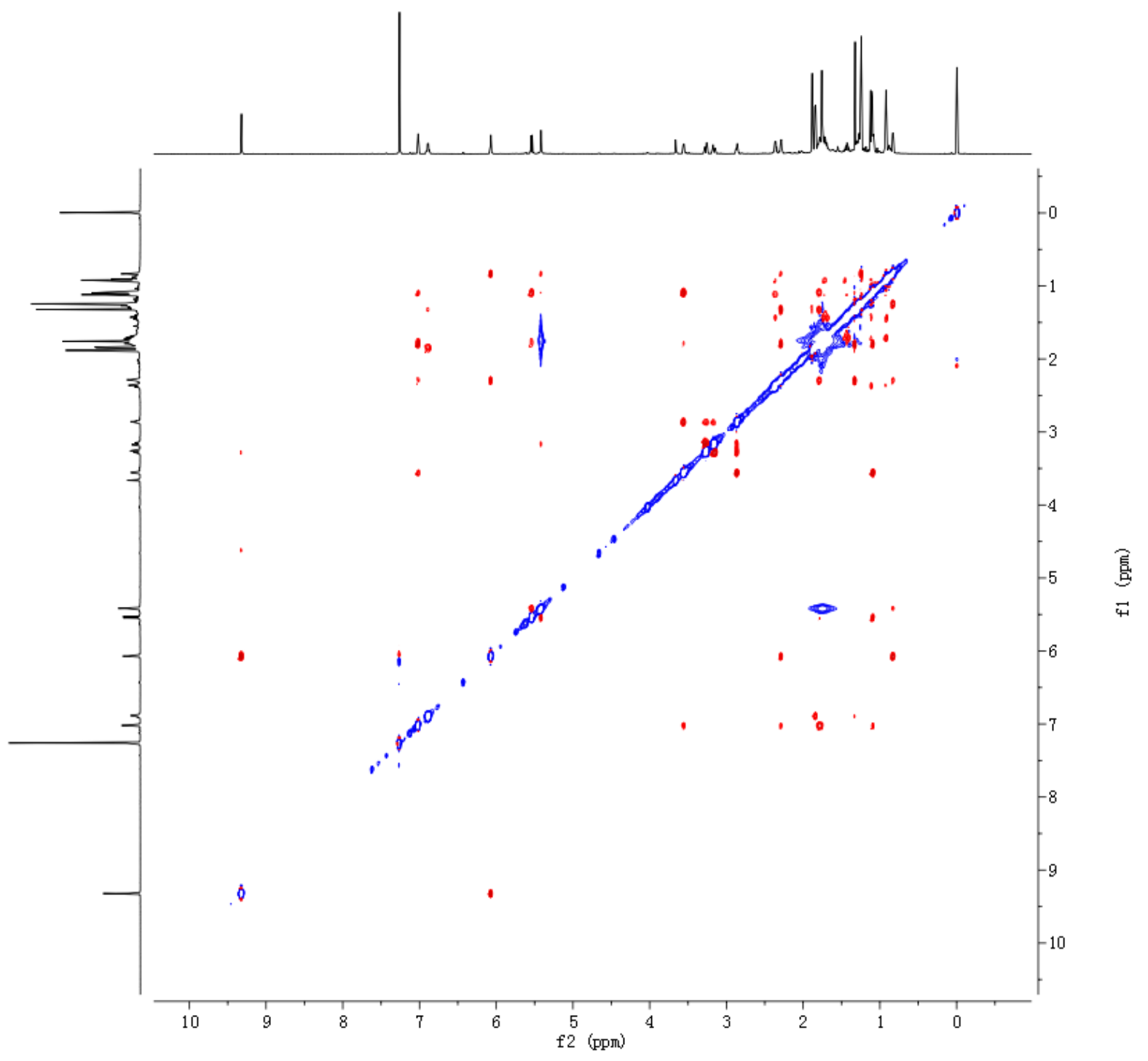


Figure S90. (+)-ESIMS spectrum of compound 9.

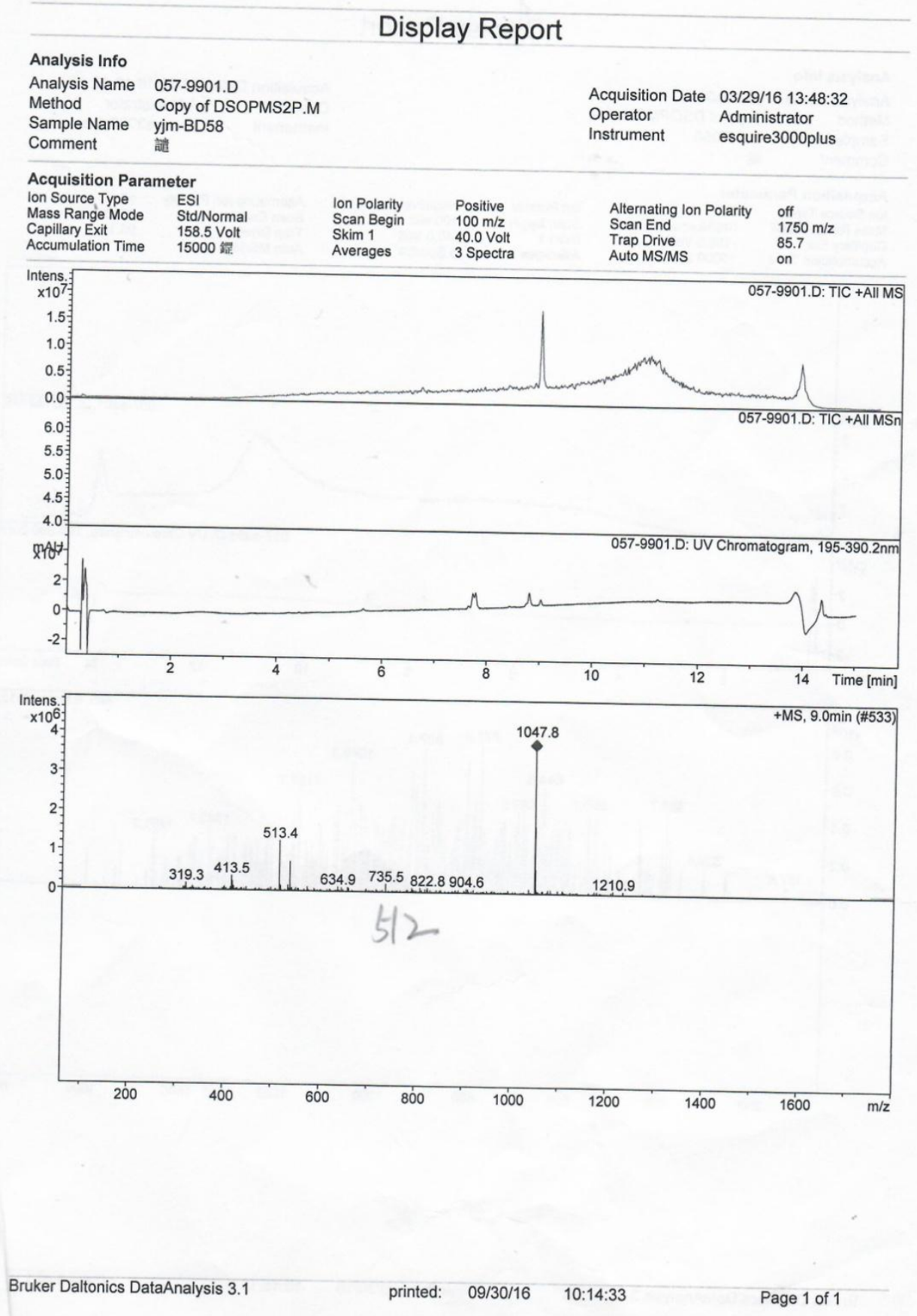


Figure S91. (+)-HRESIMS spectrum of compound 9.

Elemental Composition Report

Page 1

Single Mass Analysis

Tolerance $=1.0$ PPM / DBE: $\min =-1.5, \max =50.0$

Element prediction: Off

Number of isotope peaks used for $\mathrm{i}-\mathrm{FIT}=3$

Monoisotopic Mass, Even Electron lons

250 formula(e) evaluated with 1 results within limits (up to 50 best isotopic matches for each mass)

Elements Used:

$\begin{array}{llll}\text { C: } 5-80 & \text { H: } 2-120 & \text { O: } 0-30 \quad \mathrm{Na}: 0-1\end{array}$

LCT PXE KE324

30-Jun-2017

1: TOF MS ES+

(2)

${ }^{100}$

$\left.{ }^{100}\right]$

(n)

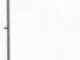

BD-58 65 (1.395) $\mathrm{Cm}$ (59:04:56)

$5.91 \mathrm{e}+003$

$\%$

-
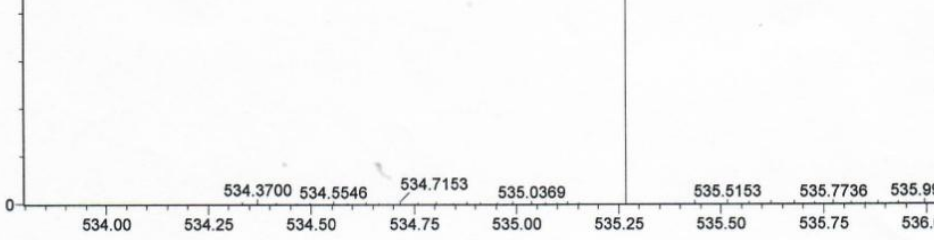

Minimum:

$\begin{array}{lllll}534.00 & 534.25 & 534.50 & 534.75 & 535.00\end{array}$

-1.5
50.0

Mass Calc. Mass mDa PPM DBE

BEE i-FIT i-FIT (Norm) Formula

$535.2670 \quad 535.2672$

$-0.2$

$-0.4$

$10.5 \quad 101.5$

0.0

$\begin{array}{lllll}\mathrm{C} 30 & \mathrm{H} 40 & 07 & \mathrm{Na}\end{array}$ 
Figure S92. IR spectrum of compound 9.

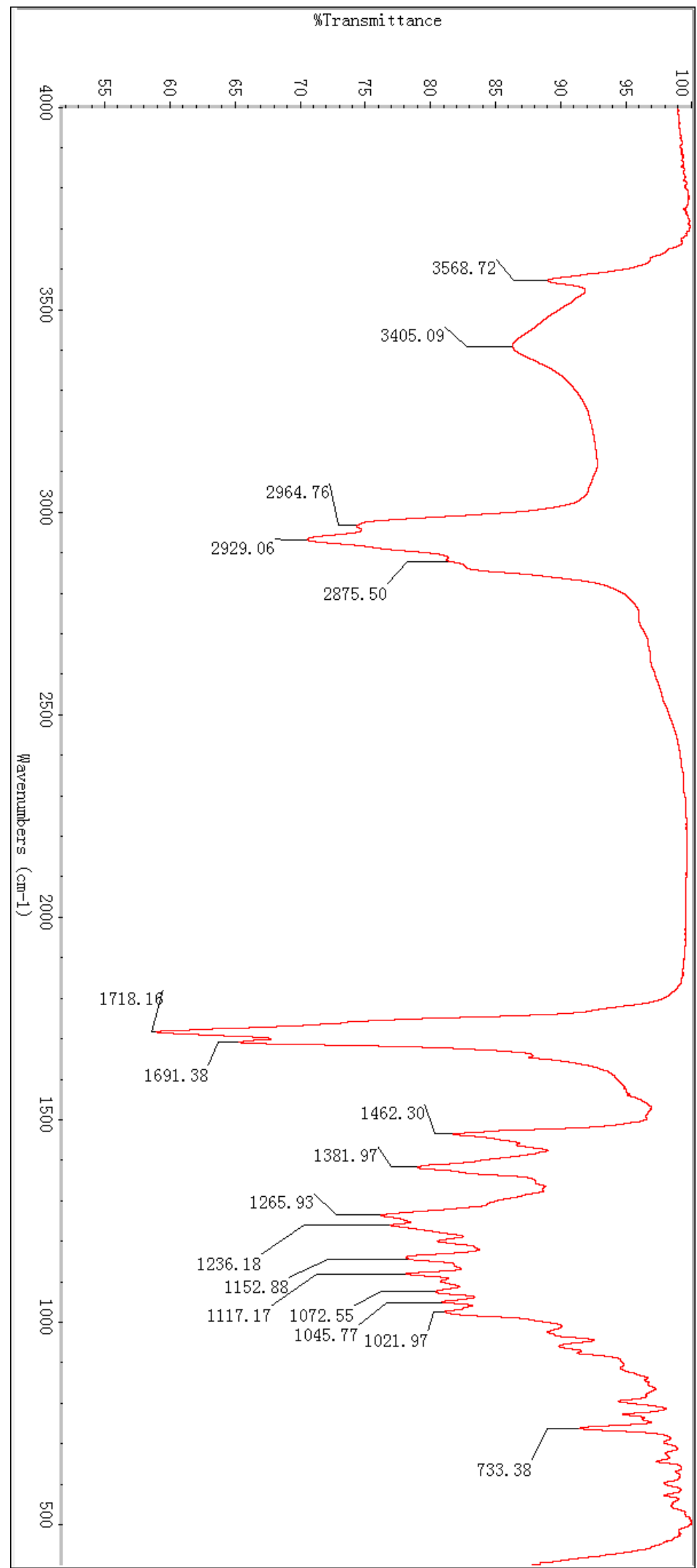


Figure S93. ${ }^{1} \mathrm{H}$ NMR spectrum of compound $\mathbf{1 0}$ in $\mathrm{CDCl}_{3}$.

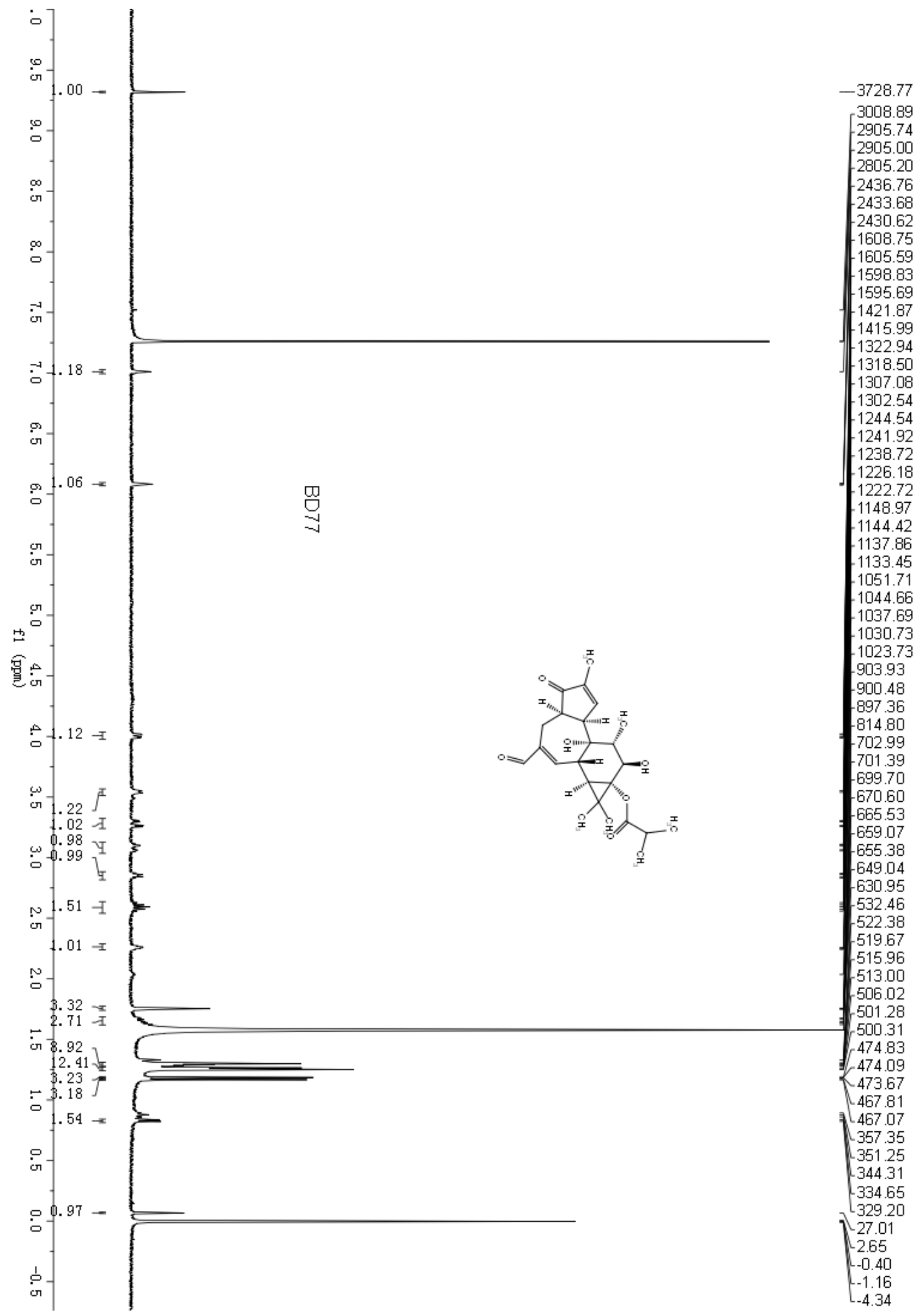


Figure S94. ${ }^{13} \mathrm{C}$ NMR spectrum of compound 10 in $\mathrm{CDCl}_{3}$.

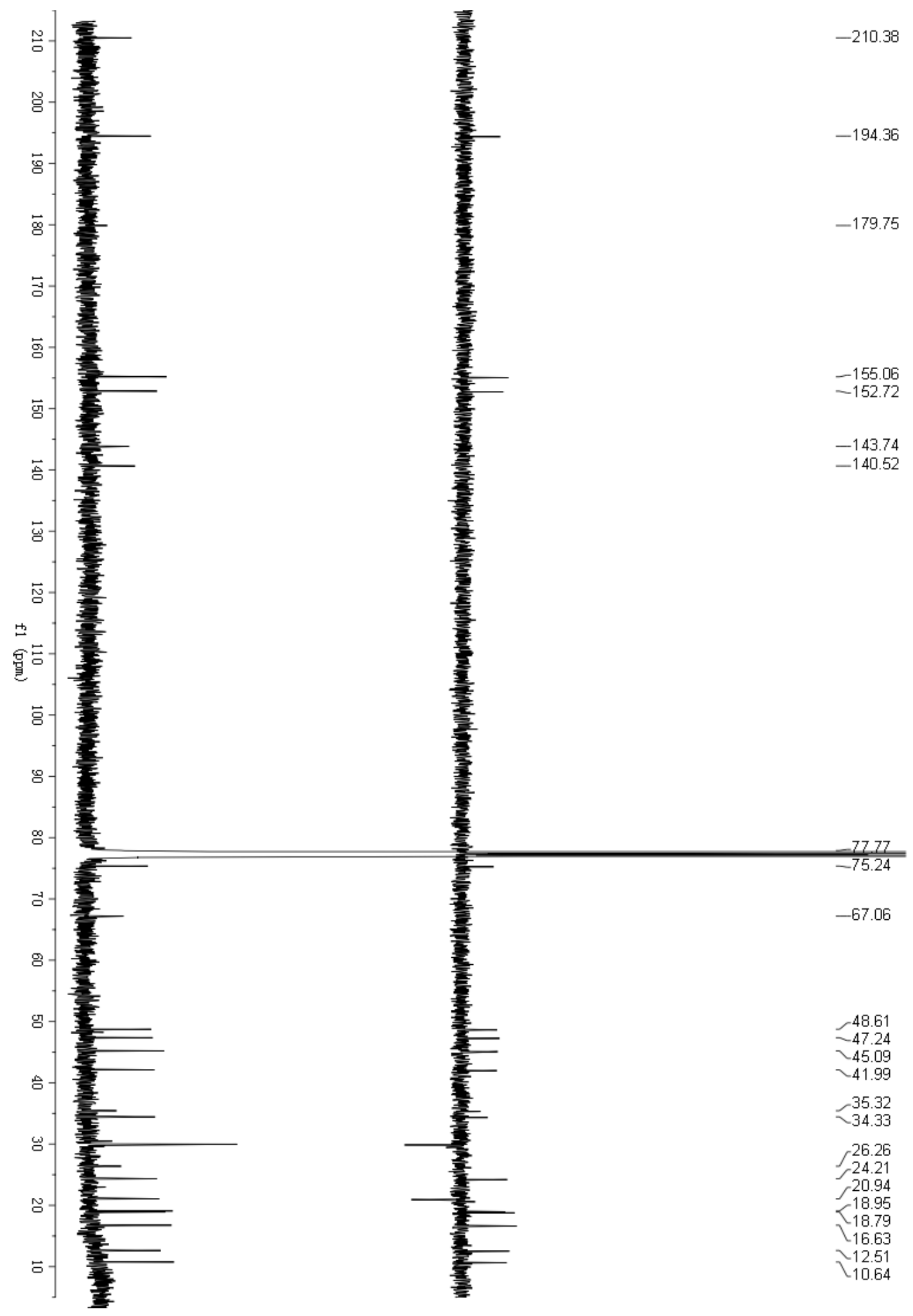


Figure S95. HSQC spectrum of compound $\mathbf{1 0}$ in $\mathrm{CDCl}_{3}$.

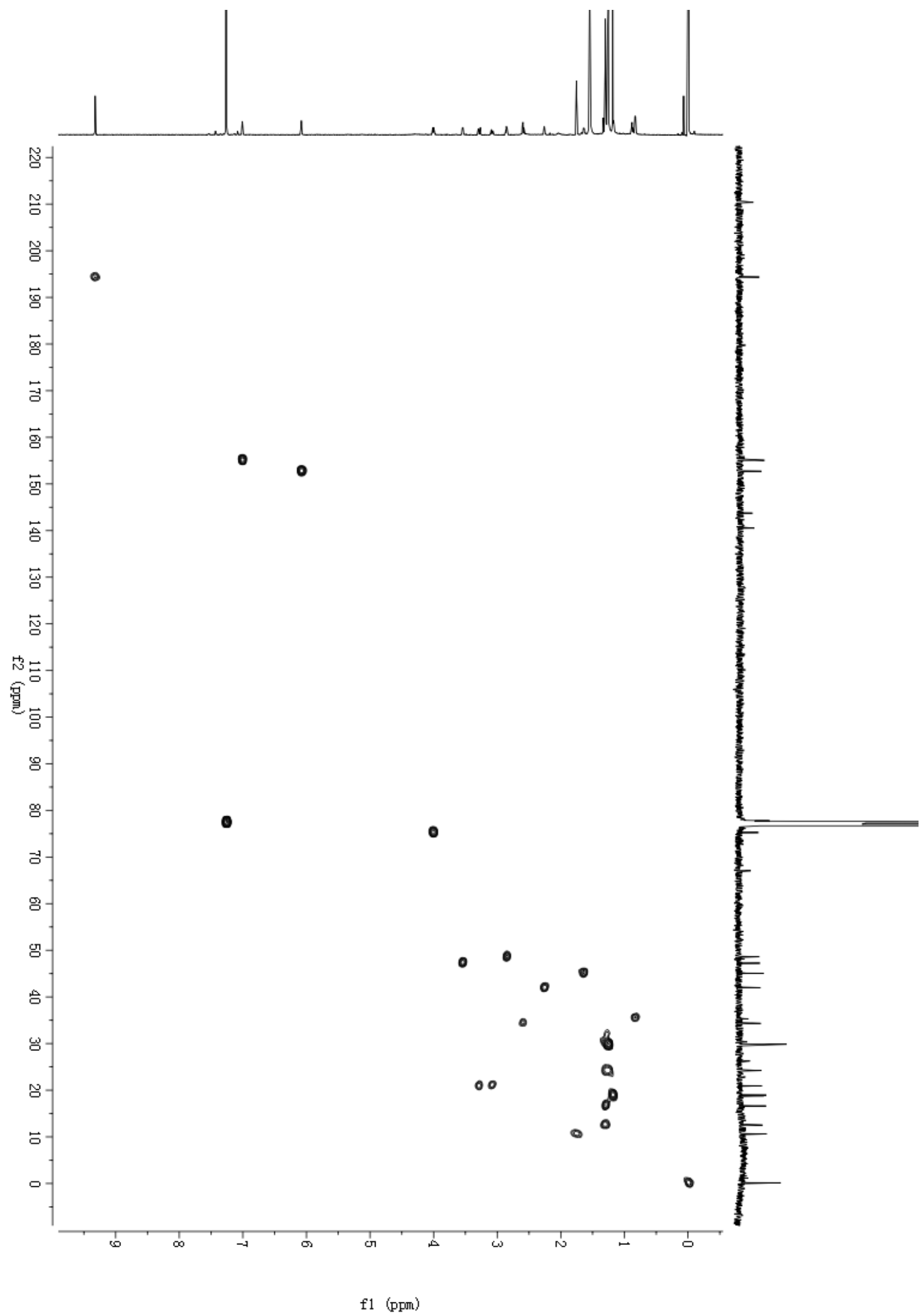


Figure S96. ${ }^{1} \mathrm{H}-{ }^{1} \mathrm{H}$ COSY spectrum of compound $\mathbf{1 0}$ in $\mathrm{CDCl}_{3}$.

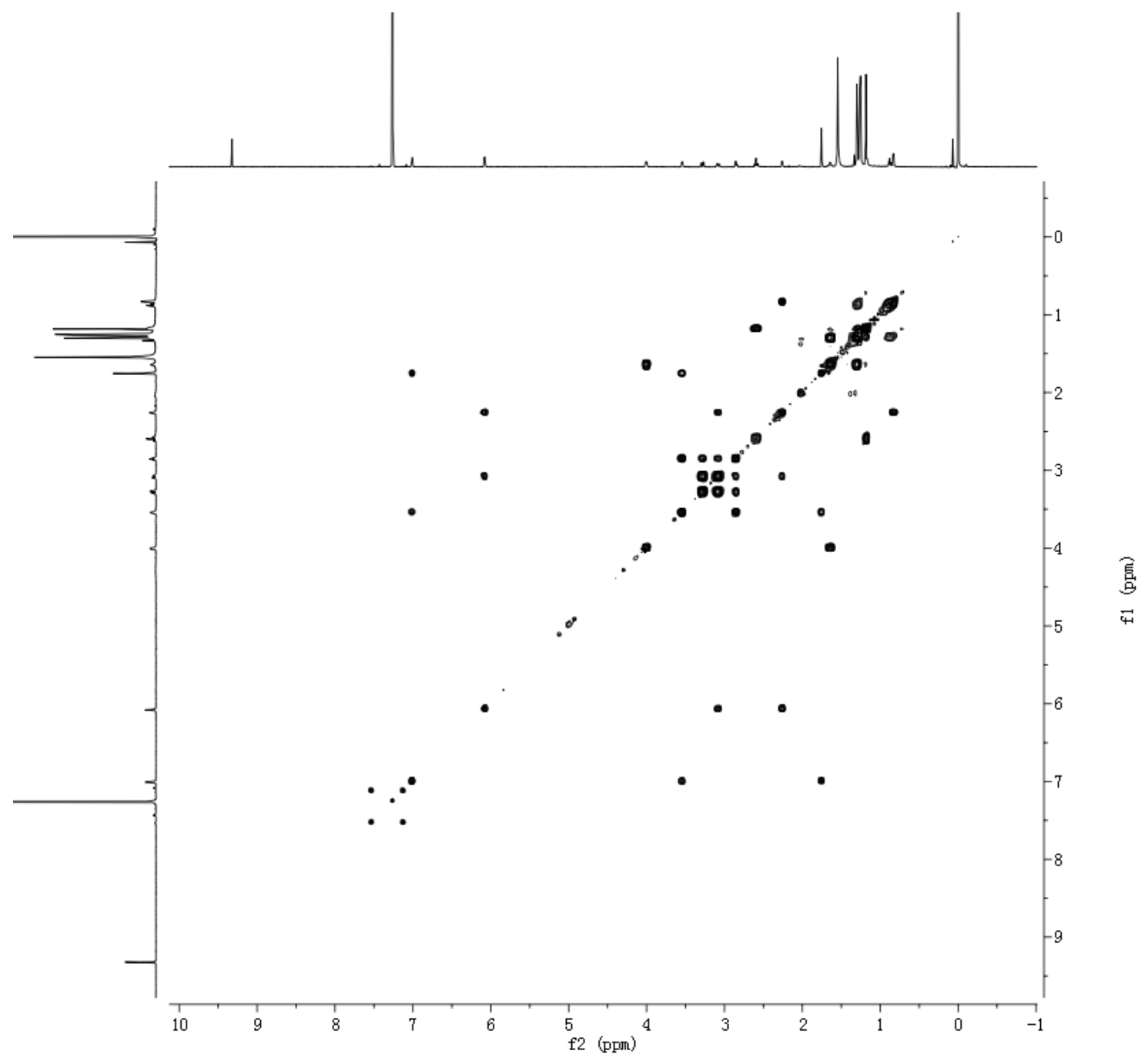


Figure S97. $\mathrm{HMBC}$ spectrum of compound $\mathbf{1 0}$ in $\mathrm{CDCl}_{3}$.

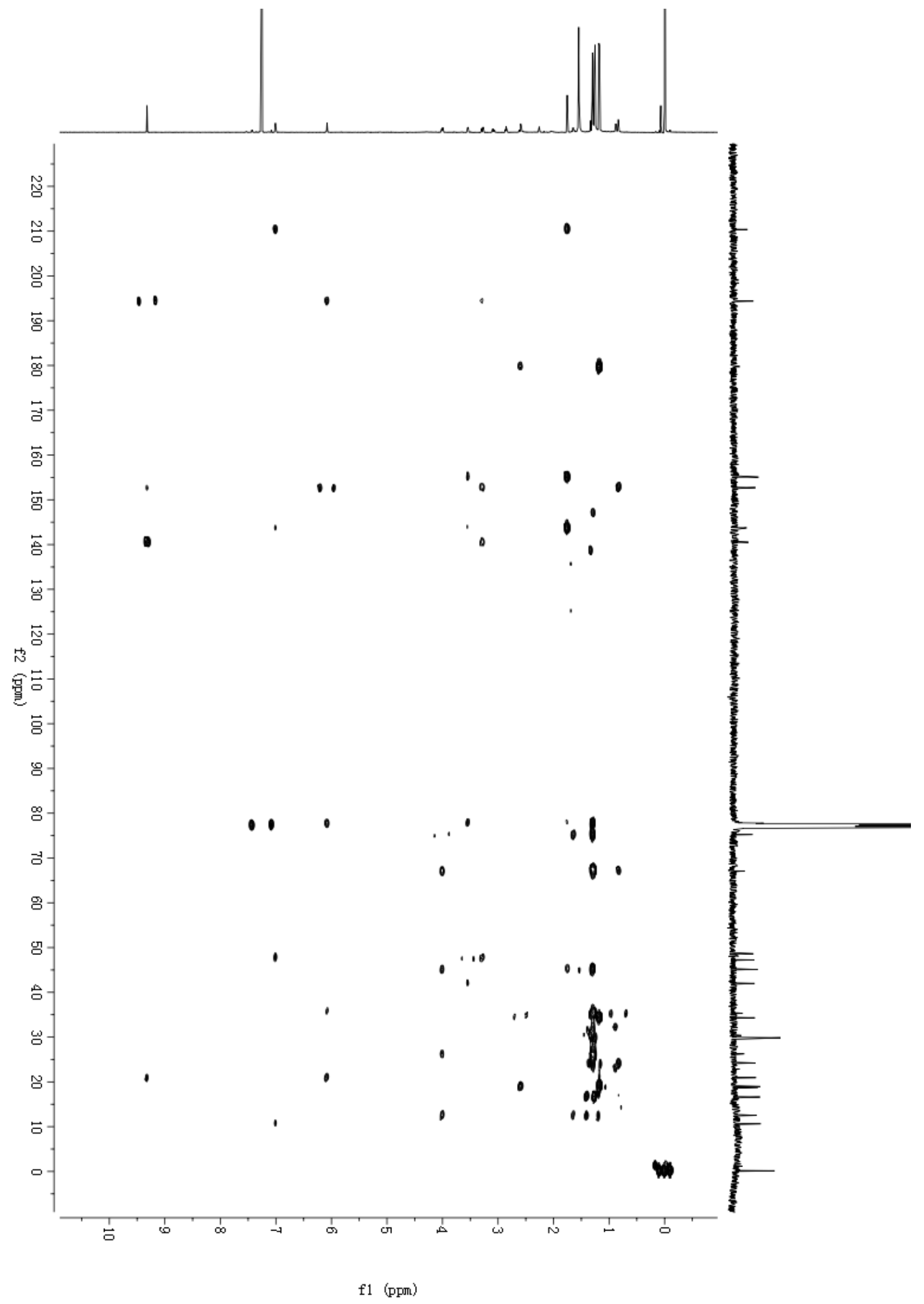


Figure S98. NOESY spectrum of compound $\mathbf{1 0}$ in $\mathrm{CDCl}_{3}$.

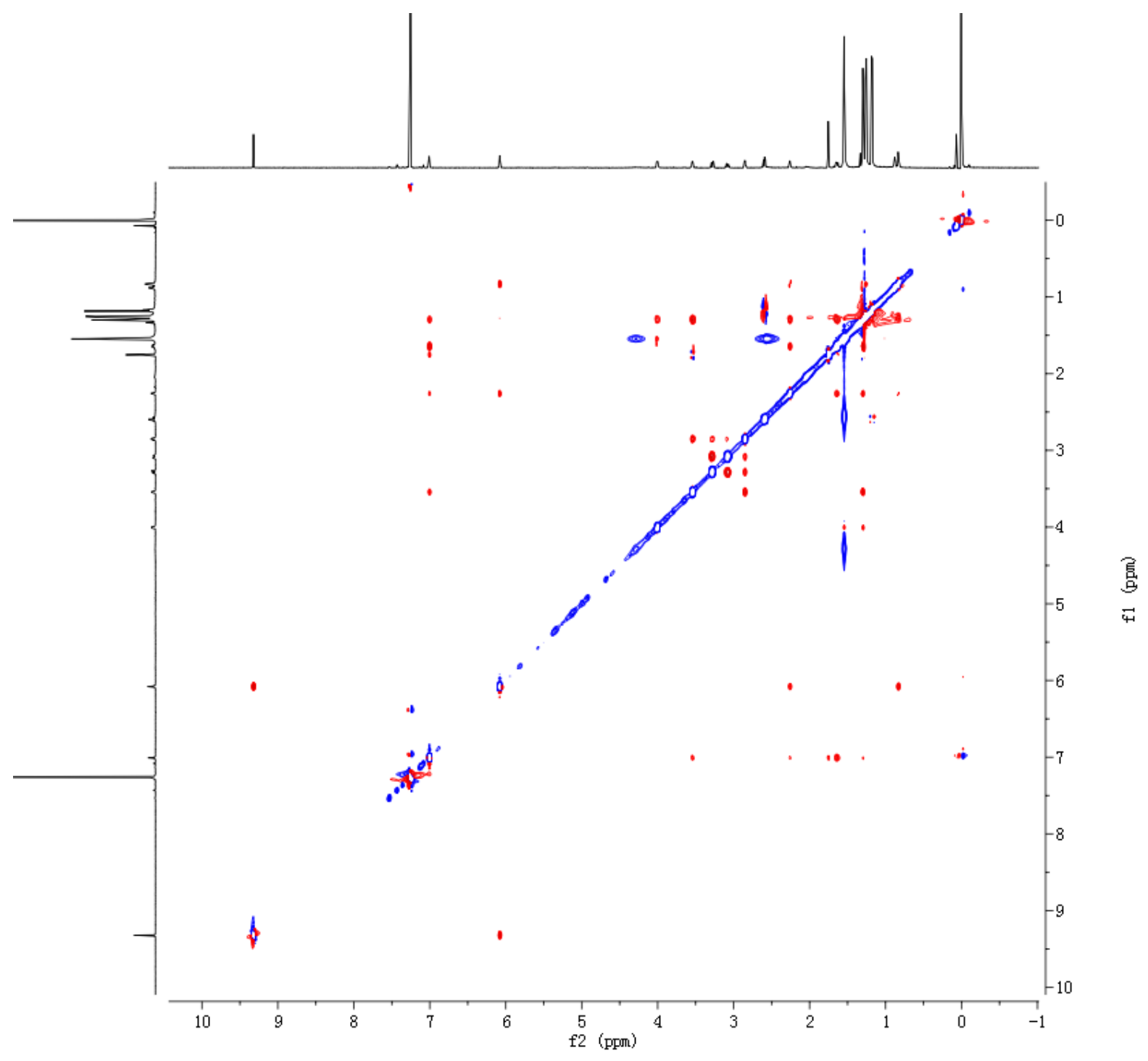


Figure S99. (+)-ESIMS spectrum of compound 10.

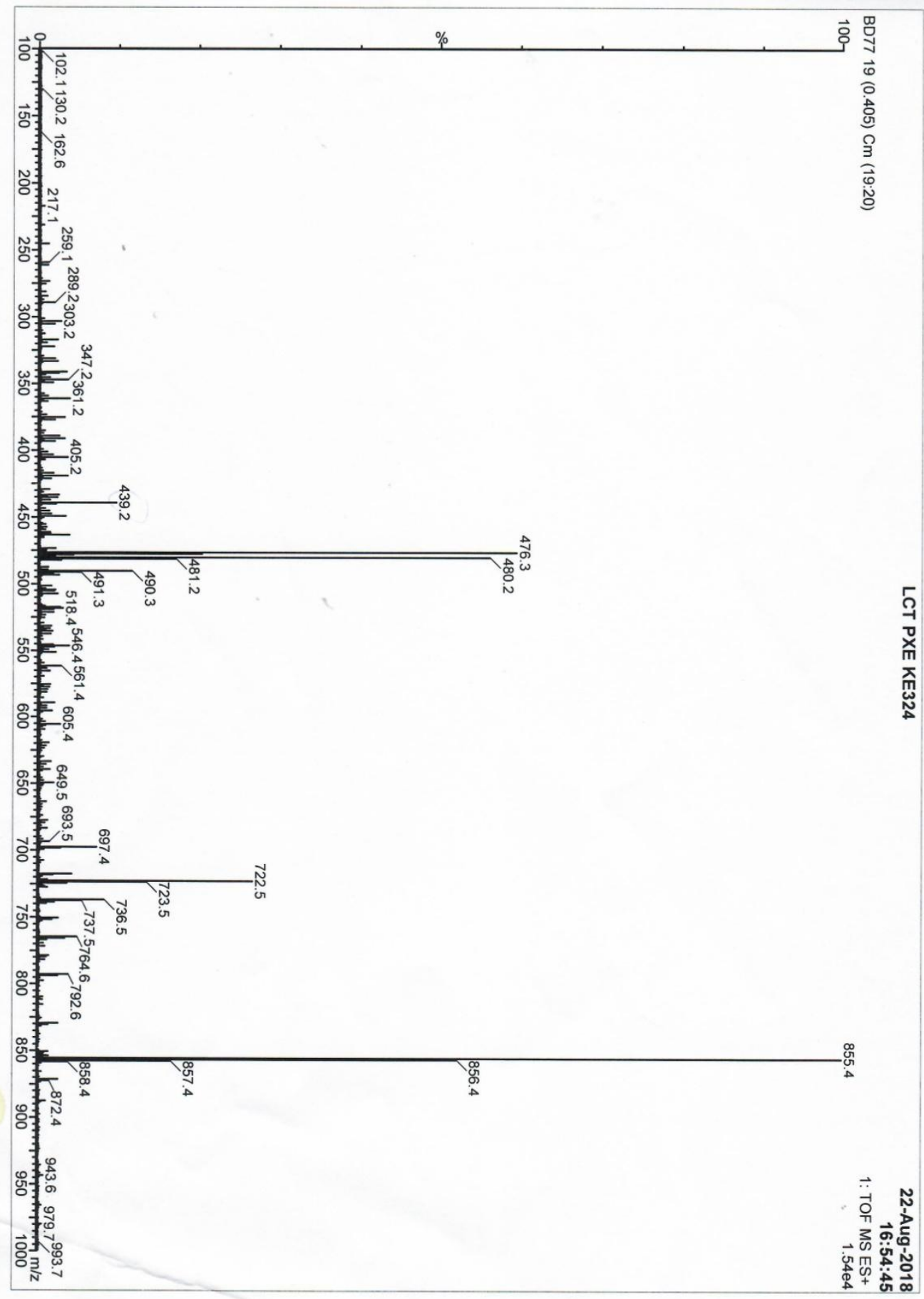


Figure S100. (-)-ESIMS spectrum of compound 10.

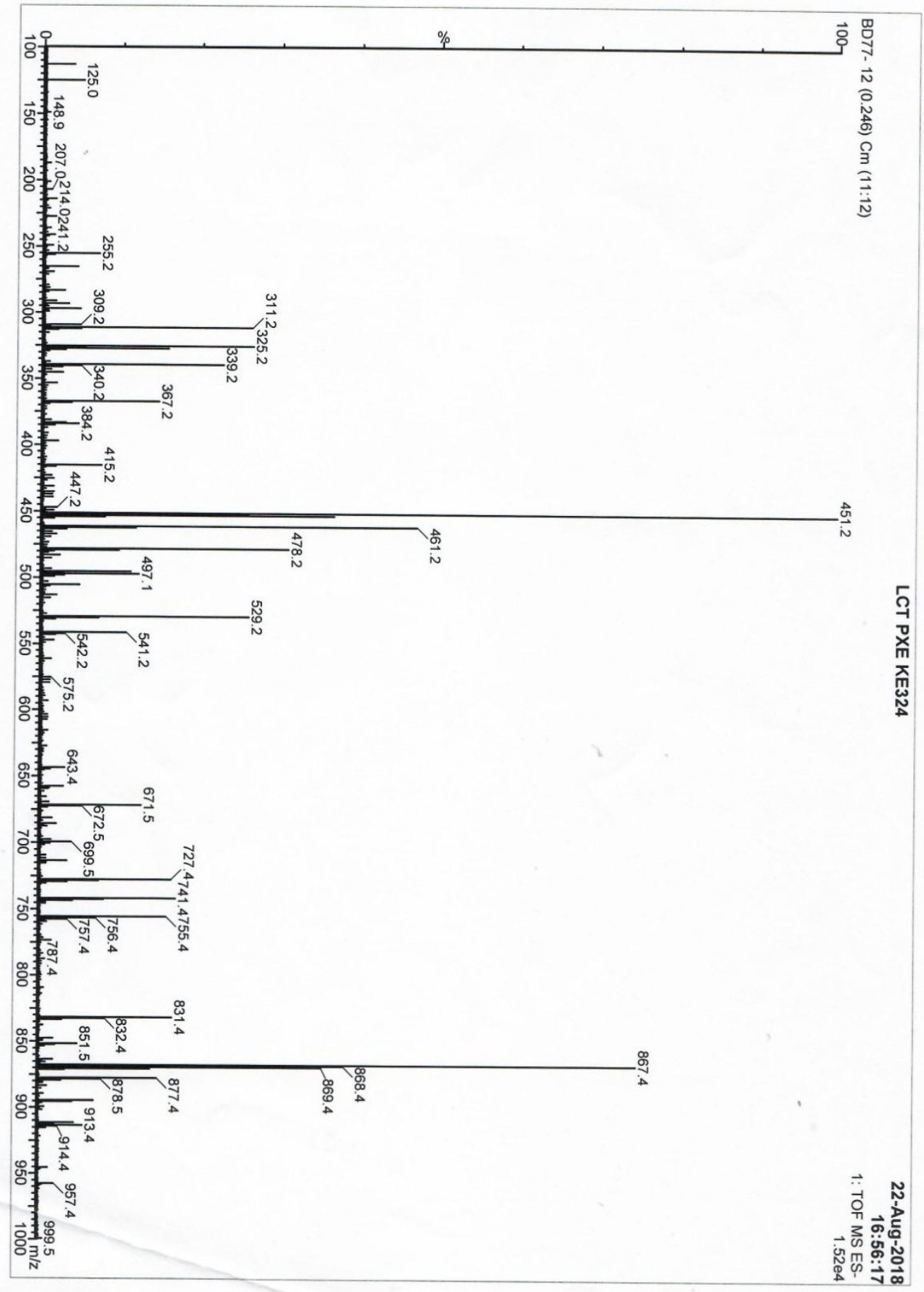


Figure S101. (+)-HRESIMS spectrum of compound $\mathbf{1 0}$.

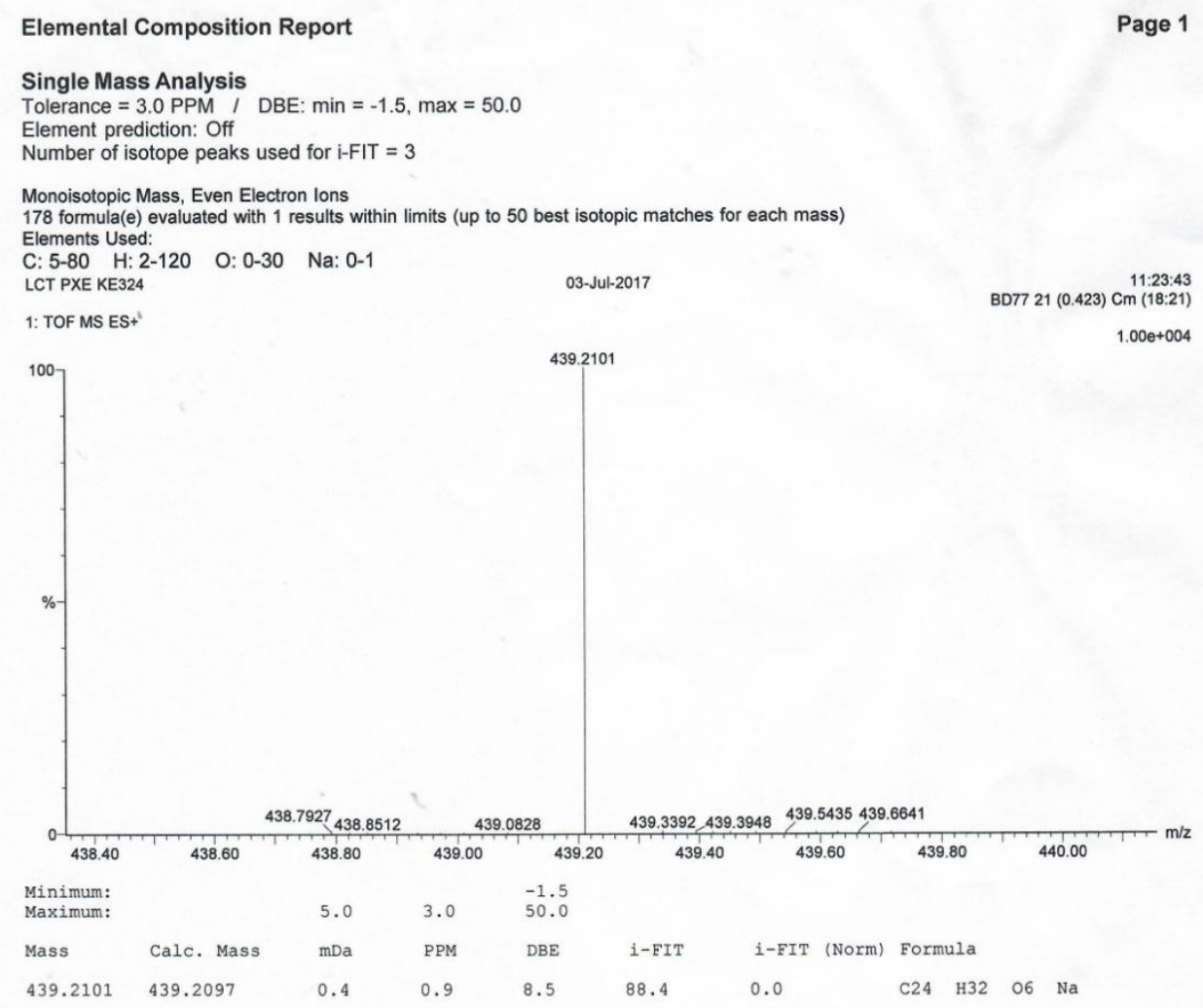


Figure S102. IR spectrum of compound $\mathbf{1 0}$.

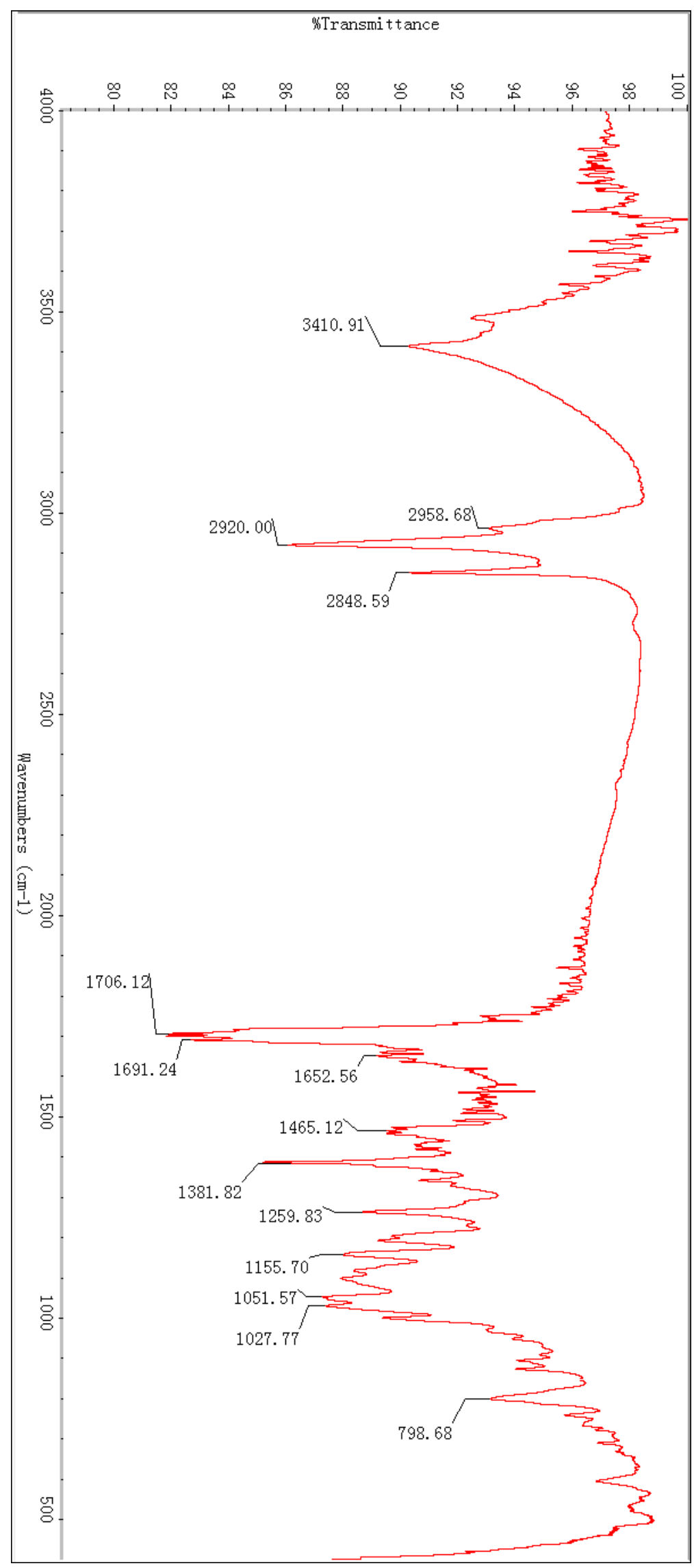

